\title{
Coping with the army: the military and the state in the New Kingdom
}

\author{
Andrea M. Gnirs
}

\author{
$\S 1$ Introduction \\ $\S 2$ Political power of the army \\ $\S 3$ State bureaucracy and "navy" \\ $\S 3.1$ Military functions and ranks in the "navy" \\ $\S 3.2$ Naval administration \\ $\S 4$ State bureaucracy and army \\ $\S 4.1$ The Royal Guard \\ $\S 4.2$ Abuse of military authority \\ $\S 4.3$ Military management, workforces, and army logistics \\ $\S 4.4$ Military administration abroad \\ $\S$ 4.4.1. Nubian provincial administration and the military \\ $\S$ 4.4.2. Foreign administration and the military in Asia \\ $\S$ 4.4.3 Supplies of troops, fortresses and garrisons \\ $\S 4$.5. Soldiers' civil careers: Aspects of a loyalistic model of the state \\ $\S 5$ Conclusions
}

\section{§ 1 Introduction}

In ancient Egypt, centralized power was always connected with a (sanctioned) use of violence and the control of armed forces. Historical evidence shows that at least from the Middle Kingdom, the mastery of specialized weapons, the organization of manpower, leadership, and battle experience were basic features of any claim to the throne. An efficient bureaucracy and military organization guaranteed political stability and success in Egypt and aborad. Both sectors flourished particularly during the earlier New Kingdom until the beginning of the $19^{\text {th }}$ Dynasty, when Egypt made her appearance on the political stage in Syria and the Levant and became one of the leading super-powers of the ancient Near East. ${ }^{1}$

One major achievement of the New Kingdom-with possible roots in the Late Middle Kingdom-was the change from a rather heterogeneous economic administration controlled by municipal or provincial governments towards a more tightened bureaucracy centralized in the royal residence. In the Middle Kingdom, the organization of the military and related branches depended on the same system of regional administrations. Implicitly corroborating the socioeconomic importance of township, soldiers were called anx.w n.w nw.t, literally "(armed) inhabitants of a town", i.e., "soldiers of a town regiment", ${ }^{2}$ later changed into anx.w n.w

\footnotetext{
${ }^{1}$ A. M. Gnirs, „Ancient Egypt“, in: War and Society in the Ancient and Medieval Worlds. Asia, the Mediterranean, Europe, and Mesoamerica, K. Raaflaub and N. Rosenstein eds. (Cambridge, MA, and London, 1999), 83-89, and A. J. Spalinger, War in Ancient Egypt. The New Kingdom (Malden, Oxford and Carlton, 2005), 1-208. For a thorough reading of my article and comments I am most grateful to Antonio Loprieno and Matthias Müller.

${ }^{2}$ This designation was still in use during the Second Intermediate Period, see S.R. Snape, ,Statues and soldiers at Abydos in the Second Intermediate Period", in: The Unbroken Reed. Studies in the Culture and Heritage of Ancient Egypt in Honour of A.F. Shore, C. Eyre, A. Leahy and L. Montagno Leahy eds. (London: Egypt Exploration Society Occasional Publications 11, 1994), 312.
} 
$\mathrm{mSa}$, "soldiers of the army". ${ }^{3}$ According to the so-called Semnah Despatches, they were sent out from their towns or nomes for state service to the Egyptian fortresses in Nubia, where they were under the control of city-administrators and Smsw.w, literally "retainers" or "guardsmen". The Nubian forts were also occupied by combat soldiers named after their Egyptian hometown, aHA.wtj nj Nxn, "Warrior from Hierakonpolis", etc. ${ }^{4}$, some of whom were also distinguished as "Commander of the Crew of the Ruler", ATw nj Tt HqA, "Head Commander of the Town Regiment", ATw aA n nw.t, and/or "Retainer of the Ruler", Smsw n HqA. ${ }^{5}$ During the war-torn late $2^{\text {nd }}$ Intermediate Period, Upper-Egyptian governors and town-commanders defended their territory by deploying local armed forces ${ }^{6}$. Then, during the $18^{\text {th }}$ Dynasty, the military was expanded and put under the direct control of the central government. With the reunification of the kingdom, maintaining "private" troops and armories at provincial courts was no longer practised. Egypt's territorial expansion and hegemonial policy brought about new bureaucratic, diplomatic, military and intelligence facilities, units and channels. A military class-consciousness articulated in biographical inscriptions and royal narratives emerged from the $2^{\text {nd }}$ Intermediate Period on, changing social ideas and values. ${ }^{7}$ Centralization and development required an updating of functions and hierarchies as well as of logistic and administrative structures. Purely military careers became possible and were, in general, restricted to elite forces, bowmen troops and the chariotry. ${ }^{8}$ Although the deployment of mercenaries ${ }^{9}$ and former captives of war trained as soldiers was a common practice throughout Egyptian history, their numbers increased considerably, especially during the Ramesside Period, ${ }^{10}$ and foreign knowhow in combat

\footnotetext{
${ }^{3}$ See e.g. the Decree of king Horemheb, 11. 16, 27 and 33, J.-M. Kruchten, Le Décret d'Horemheb. Traduction, commentaire épigraphique, philologique et institutionnel (Brussels: 1981), 28-31, 80-83, 90, 116-126.

${ }^{4}$ pBM EA 10752+10771, P.C. Smither, "The Semnah Despatches", JEA 31 (1945), 3-10, pls. I-VII. On the titles anx/ATw nj nw.t see O. Berlev, „Les prétendus ,citadins’ au Moyen Empire“, RdE 23 (1971), 23-48. On
}

Smsw and aHA.wtj see S. Quirke, “The Regular Titles of the Late Middle Kingdom”, RdE 37 (1986), 122f., D. Stefanovič, The Holders of Regular Military Titles in the Period of the Middle Kingdom: Dossiers (London: GHP Egyptology 4, 2006), 95-170 (Smsw) and 178-181 (aHA.wtj), and P.-M. Chevereau, „Contribution à la prosopographie des cadres militaires du Moyen Empire“, RdE 42 (1991), 71 on Smsw with further bibliography.

${ }^{5}$ See e.g. the titles born by Huysobek from the late $12^{\text {th }}$ Dynasty, Stefanovic, Holders, 180f. No. 974 1) with further bibliography.

${ }^{6}$ See, for instance, the biographical inscription in the tomb of Djehutinacht at El-Kab, W.V. Davies, ,Kush in Egypt: A New Historical Inscription“, Sudan \& Nubia 7 (2003), 52-54, and id., ,Sobeknakht of Elkab and the Coming of Kush“, Egyptian Archaeology 23 (Autumn 2003), 3-6. Cf. also Snape, in: The Unbroken Reed, 1994, 311-313.

${ }^{7}$ A.M. Gnirs and A. Loprieno, "Krieg und Literatur", in: Militärgeschichte des pharaonischen Ägypten. Altägypten und seine Nachbarkulturen im Spiegel aktueller Forschung, R. Gundlach and C. Vogel eds. (Paderborn, München, Wien, Zürich: Krieg in der Geschichte 34, 2009), 267-279.

${ }^{8}$ Cf. A. M. Gnirs, Militär und Gesellschaft. Ein Beitrag zur Sozialgeschichte des Neuen Reiches, (Heidelberg: SAGA 17, 1996), 17-39.

${ }^{9}$ See, for instance, R. Friedman, "The Nubian Cemetery at Hierakonpolis, Egypt. Results of the 2007 Season. The C-Group Cemetery at Locality HK27C", Sudan \& Nubia 11 (2007), 57-62, and J. Bourriau, "Relations between Egypt and Kerma during the Middle and New Kingdoms", in: Egypt and Africa. Nubia from Prehistory to Islam, W.V. Davies ed. (London: 1991), 130-132, on Nubian mercenaries during the early Middle Kingdom resp. the Second Intermediate Period, and more general A.M. Gnirs, "Ancient Egypt", in: War and Society in the Ancient and Medieval Worlds. Asia, The Mediterranean, Europe, and Mesoamerica, K. Raaflaub and N. Rosenstein eds. (Cambridge, Mass., London: 1999), 77-92, and ead., "Military. An Overview", in: The Oxford Encyclopedia of Ancient Egypt, D.B. Redford ed., vol. 2 (Oxford, New York: 2001), 402-405.

${ }^{10} \mathrm{~B}$. Menu, "Captifs de guerre et dépendance rurale dans l'Égypte du Nouvel Empire", in: La dépendance rurale en Égypte ancienne et dans l'Antiquité proche-orientale, B. Menu ed. (Cairo: BdE 140, 2004), 187-209. 
techniques and technologies found its way into Egypt, ${ }^{11}$ having an impact on military ranking and nomenclature. ${ }^{12}$ At the same time, the social status of foreign specialists and warriors was enhanced, many of whom gave up their original identity and assumed an Egyptian name. The overall enlargement of the Egyptian army during the later New Kingdom, a consequence of the increase of economic resources and manpower on the one hand and of altered warfare practices on the other, necessitated a broader network of military facilities. ${ }^{13}$

\title{
§ 2 Political power of the army
}

The military organization always maintained strong ties with the King's House. According to official display, as Commander-in-Chief of the Army the king led the Egyptian forces to war, but de facto, he was often represented by his oldest son and designated crown prince. The topic of the king's martial skills and war deeds is already fully developed during the later Middle Kingdom, ${ }^{14}$ as was the crown prince's role as war hero in place of the elderly king (story of Sinuhe). ${ }^{15}$ During the New Kingdom, the belligerent nature of kingship was even more emphasized. At a time, when Egypt first ensured, then enhanced its territorial claims and strived for hegemonial control in the ancient Near East, the military qualifications of the ruler were pivotal and shaped the role of the heir apparent as chief executive in foreign policy and in the military organization. Early in the $18^{\text {th }}$ Dynasty, these skills were not connected with a specific ranking title, but the claim to the throne was based on qualification rather than on inheritance. In this respect, a passage from the Tombos Inscription of Thutmose I may be elucidating: ${ }^{16}$

\author{
„Second year of his initiation (bzw.t=f), \\ of his appearance as Chief of the Two Lands (Hrj-tp tA.wj), \\ to dominate what Aten encircles, ......., \\ who established himself on the throne of Geb $(\mathrm{znDm}=\mathrm{f})$... “
}

In this text, the future king is presented as a "civic" leader in waiting (Hrj-tp tA.wj) ready to be installed in office (bsj). Around the same time, Thutmose's eldest son Amenmose held the rank of a Generalissimo, jmj-rA mSa wr, "of his father". ${ }^{17}$ The title, which had already

\footnotetext{
${ }^{11}$ I. Shaw, "Egyptians, Hyksos and Military Hardware: Causes, Effects or Catalysts?”, in: The Social Context of Technological Change. Egypt and the Near East, 1650-1550 BC. Proceedings of a Conference Held at St. Edmund Hall, Oxford 12-14 September 2000, A. J. Shortland ed. (Oxford: 2001), 59-71; P. R. S. Moorey, "The Mobility of Artisans and Opportunities for Technology Transfer between Western Asia and Egypt in the Late Bronze Age", loc.cit., 1-14, and A. Herold, “Aspekte ägyptischer Waffentechnologie - von der Frühzeit bis zum Ende des Neuen Reiches”, in: Militärgeschichte des Pharaonischen Ägypten, 201-215.

${ }^{12}$ T. Schneider, "Fremdwörter in der ägyptischen Militärsprache des Neuen Reiches und ein Bravourstück des Elitesoldaten (Papyrus Anastasi I 23,2-7)”, JSSEA 35 (2008), 181-205.

${ }^{13}$ Gnirs, Militär und Gesellschaft, 57-66, 165-172.

${ }^{14}$ For the motive of the victorious king in literature and historiography of the Middle Kingdom, see Gnirs and Loprieno, in: Militärgeschichte des pharaonischen Ägypten, 252-257.

15 The literary text is transmitted from the second half of the $12^{\text {th }}$ Dynasty onwards, R.B. Parkinson, ,The Missing Beginning of, The Dialogue of a Man and His Ba': P. Amherst III and the History of the ,Berlin Library"“, Z̈̈S 130 (2003), 124f.

${ }^{16}$ Tombos Inscription of Thutmose I, 11. 1-2 (Urk. IV, 82:12-16), cf. A. Klug, Königliche Stelen in der Zeit von Ahmose bis Amenophis III (Brepols: MonAeg 8, 2002), 71-78, 504-506 (bibliography), and P. Beylage, Aufbau der königlichen Stelentexte von Beginn der 18. Dynastie bis zur Amarnazeit, Teil I: Transkription und Übersetzung der Texte (Wiesbaden: ÄAT 54.1, 2002), 209-219. On the possible circumstances of the king's enthronement, see A. Dodson and D. Hilton, The Complete Royal Families of Ancient Egypt (London: 2004), 128, and F. Maruéjol, Thoutmosis III et la corégence avec Hatchepsout (Paris: 2007), $20 \mathrm{f}$.

${ }^{17}$ Fragment of a naos, now Louvre E 8074, Urk. IV, 91:12.
} 
been in use during the Middle Kingdom, ${ }^{18}$ was not common during the earlier $18^{\text {th }}$ Dynasty, which corroborates the idea that during this period, it was exclusively linked to the supreme army command laid in the hands of the king's eldest son and designated successor to the throne. ${ }^{19}$ Webensenu, probably a son of Amenhotep II, ${ }^{20}$ bore the title of a jmj-rA-ssm.wt, "Marshal", who controlled the military department of the chariotry. His inscriptions, however, do not mention the rank of the "eldest son". ${ }^{21}$ Another princely Marshal from the reign of Amenhotep II left a stela in the Sphinx temple at Giza. Although the individual's name and some of his titles are erased, the plaited side-lock of youth, the cartouche in front of his face, in which his name must have been written, as well as some specific epithets characterize him as royal offspring. ${ }^{22}$ His executive position within the chariotry is reflected by the

\footnotetext{
${ }^{18}$ Chevereau, RdE 42 (1991), 44-46, No. 1-13.

${ }^{19}$ Gnirs, Militär und Gesellschaft, 6.

${ }^{20}$ As remains of his burial were found in KV 35, the tomb of Amenhotep II, Webensenu is usually taken as one of his sons, see Dodson and Hilton, Complete Royal Families, 134f., 141.

${ }^{21}$ The title appears on a calcite canopic jar found in KV 35, Cairo CGC 5031, M G. Daressy, Fouilles de la Vallée des Rois, CGC 24001-24990 (Kairo: 1902), 224; according to Daressy, the canopic lids in the shape of human heads, CGC 5032, belonged to the same canopic ensemble, ibid., 245; Webensenu's shabtis, in contrast, only bear the title zA-nsw, CGC 24269-24271, perhaps also CGC 24272-24273, which do not mention the prince's name, see Daressy, Fouilles, 103f., pl. 26; cf. P.-M. Chevereau, Prosopographie des cadres militaires Égyptiens du Nouvel Empire (Antony: 1994), 46 No. 7.07, and Gnirs, Militär und Gesellschaft, 22. Finally, a prince Webensenu is also mentioned on a statue of the Royal Cupbearer, City Governor, Director of the Priests of Month Lord of Thebes and Director of Works in the Temples of all Egypt Minmose, a former campaign companion of Thutmose III, Cairo CGC 638; it is a block statue with the heads of two princes to the right resp. the left of Minmose's face, one of which is designated as “the King's Son Web[en-senu]", L. Borchardt, Statuen und Statuetten von Königen und Privatleuten im Museum von Kairo Nr. 1-1294, vol. 2. CGC 1-1294 (Kairo: 1925), 186f., pl. 117, and Urk. IV, 1447:20. C.H. Roehrig, The Eighteenth Dynasty Titles Royal Nurse (mnat
} nswt), Royal Tutor (mna nswt), and Foster Brother/Sister of the Lord of the Two Lands (sn/snt $\mathrm{mna} \mathrm{n} \mathrm{nb}$

tAwy) (Ann Arbor: UMI 1990), 285f., pls. 12-13, places Minmose, whose specific tutor's functions in the King's House are not mentioned on his monuments, in the reign of Thutmose III. H. de Meulenaere, "Le directeur des travaux Minmose", MDAIK 37 (1981), 317f., suggests that he might have lived to the position of a Royal Tutor when his daughter $\gtrsim \mathbb{A}$-ry-tj became a Royal Nurse. There is no definite proof of Webensenu being Amenhotep II's bodily son except for the fact that parts of his burial were found in the latter's tomb, but his interment in the king's tomb make it very likely, cf. remains of the original burial (canopic jars) of a son of Thutmose IV, Amenemhat, also known from other sources, in his father's tomb (KV 43), N. Reeves and R.H. Wilkinson, The Complete Valley of the Kings. Tombs and Treasures of Egypt's Greatest Pharaohs (London: 1996), 107.

${ }^{22}$ Stela No. 37 or stela „B“ according to S. Hassan, The Great Sphinx and its Secrets. Historical Studies in the Light of Recent Excavations (Cairo: Excavations at Giza 8, 1953), 85-87, fig. 68; S. Hassan, The Sphinx. Its History in the Light of Recent Excavations (Cairo: 1949), 188-189, fig. 40; C.M. Zivie, Giza au deuxième millénaire (Cairo: BdE 70, 1976), 96-105, No NE 9, and cf. Chevereau, Prosopographie, 55 No. 7.54; the present location of the stela broken in four parts is not known. A small standing figure of king Amenhotep II is shown between the paws of the sphinx; the group is followed by a figure of the falcon-headed god Re-Harachte. The prince offers a flower bouquet and a great variety of provisions depicted in a subregister between the main scene and the lower part of the stela. The inscription is of particular interest, as it mentions function and ranking titles that usually characterize high officials, rather than princes. For this reason, B. Schmitz, Untersuchungen zum Titel sA-njswt „Königssohn“ (Bonn: 1976), 300-304, argues against the identification of the stela’s owner with a royal son; on the one hand, she points out that the pair of ranking titles jrj-pa.t HA.tj-a would not appear in titularies of princes of the 18th Dynasty, on the other, she remarks that later on, in the Ramesside Period, the combination is not uncommon in title sequences of royal sons, cf. also J.M. Fisher, The Sons of Ramesses II, vol. II. Catalogue (Wiesbaden: ÄAT 53/2, 2001), 70 No 1.24 (Amunherkhepeshef), 73 No 1.31 (Sethherkhepeshef), 155 No 10.13 (Setepenre) or 205 No 50.95 (unidentified prince), for the reign of Ramesses II. Some of them also included epithets that characterized their personal position at court similar to those used by high palace-officials. This would be another parallelism to the titles reproduced on the Giza stela. The lack of evidence during the $18^{\text {th }}$ Dynasty may be linked to the scarce textual material on princes of the earlier New Kingdom. 
unconventional title of a "Supreme Marshal", Hrj-tp jmj(.w)-rA.w ssm.wt, in combination with some ranking titles and epithets that usually distinguish the highest representatives of the administration, i.e., the viziers. ${ }^{23}$ The statement that he "had access to his father without being announced", and that he "body-guarded the King of Upper- and Lower Egypt", identifies him as both a true royal son and as an elite soldier in the king's entourage. ${ }^{24}$ Since the sequences of titles are partly erased, his exact princely status in the royal house, however, cannot be deduced. In addition, the nameless prince bears the ritual titles sm xrp SnDj.t nb, smPriest and Director of all Kilts, and related epithets such as "Keeper of Secrets in the House of Ptah" and "Sem-Priest in the House of Sokar". These statements led D.B. Redford to the assumption that the prince must have been High-Priest of Ptah at Memphis, a position which is usually characterized by the titles wr $\mathrm{xrp}(. \mathrm{w})$-Hmw.w sm nj PtH, Director of Artisans and sm-Priest of Ptah. Consequently, Redford identifies the owner of the stela with the King's Son and sm-Priest in Memphis Amenhotep mentioned in pBM $10056 .{ }^{25}$ As the ritual titles sm-Priest and Director of all Kilts could be borne by other high-standing officials such as the Vizier ${ }^{26}$ and do not per se imply that the title-holder was High-Priest of Ptah, the only clearly defined function of the prince is that of the Supreme Marshal. Prince Amenhotep is, hitherto, not known to have headed the chariotry, Webensenu, in contrast, is. The stela from Giza might, thus, have been erected for Webensenu rather than for Amenhotep. ${ }^{27}$

${ }^{23} \mathrm{sAb}$ tAj.tj jrj-Nxn Hm-nTr MAa.t rA shrr m tA r-Dr=f, ,Judge, One of the Curtain, Priest of Maat, Mouth that Satisfies in the Entire Country“, 1. 4, and see below n. 26.

${ }^{24}$ L. 2; Zivie, Giza, 98f. with note b) suggests a reading aq $\mathrm{Hr} \mathrm{Hm}=\mathrm{f}$, ,who has access to His Majesty“, but the writing of the j-sign of the word is clear on the photo published by Hassan, Great Sphinx, 85 fig. 68.

${ }^{25}$ On this administrative text see below pp.8 n.46 and 12 and D. Redford, "The Coregency of Tuthmosis III and Amenophis II", JEA 51 (1965), 113-115, who takes this Amenhotep as a son of Amenhotep II, followed by Dodson and Hilton, Royal Families, 137f. („Amenhotep C“). In contrast, Schmitz, Untersuchungen, 299-300, regards him rather as a brother or uncle of the king, although there is no evidence for a prince Amenhotep from the time before the reign of Amenhotep II except the one who followed Thutmose III on the throne.

${ }^{26}$ The ritual titles sm xrp SnDj.t nb and jtj-nTr mrj-nTr, ,Sem-priest, Overseer of all Kilts“ and „Beloved God's Father" from 1. 5 of the inscription can be part of the vizier's titulary in the New Kingdom, cf. A. Weil, Die Veziere des Pharaonenreiches. Chronologisch angeordnet (Leipzig: 1908), for instance, 76 a) (Rekhmire); 86 a) (Ramose); 95 c) (Neferrenpet, who, at the same time, was also High-Priest of Ptah at Memphis, wr xrp(.w) Hmw.w sm nj PtH, „Chief Director of Artisans, Sem-Priest of Ptah“) or 104 b) (Panehsi). ${ }^{27}$ According to Hassan, The Great Sphinx, 85f. and fig. 67, and id., The Sphinx, 188f., and fig. 39, it does not seem unlikely that stelae "A" and "B" were dedicated to the same individual. In KV 35, the tomb of Amenhotep II, which also contained some objects of prince Webensenu's burial (see above n. 20-21), the mummy of an approximately 11-year old boy wearing a plaided side-lock at his head was found (now Cairo Egyptian Museum CGC 61071). While Reeves, Complete Valley of the Kings, 199, does not exclude an identification of the mummy with prince Webensenu, in his The Valley of the Kings. The Decline of a Royal Necropolis (London: 1990), 222-223, he argues against the boy's body having been originally buried in KV 35 . According to some archaeological evidence, the body could have been brought to KV 35 around the same time when royal and some other unidentified mummies were brought to Amenhotep's tomb, which had been reused as a mummies' cache from that time onwards. Princes might have been ennobled with high-ranking military ranks at an early age, especially when they were designated heirs to the throne, cf. the Quban Stela of Ramesses II, on which the king's early career as commander of the forces is unfolded: "The state of the two riversides was reported to you, when you were (still) a boy under the lock of youth. No monument was erected without being under your control. No commission came about without your knowing about it. You were the Supreme Mouth of the Army when you were a boy in his $10^{\text {th }}$ year", stela Grenoble Museum 1.33, 11. 16-17, KRI II, 356:3-6; RITA II: Translations, 191; RITA II: Notes and Comments, 214-216, cf. also Gnirs, Militär und Gesellschaft, 122f. The long sequences of titles and epithets on the Giza stela, however, rather suggest a mature age of its owner. 
Military leadership and competence as a key prerequisite of kingship became most explicit at the end of the $18^{\text {th }}$ Dynasty, after the decline of the Thutmosid dynasty, when the political status of the designee to the throne was bound both to the rank of a jrj-pa.t, Regent, and of a Generalissimo, which, from the time of Amenhotep III on, could also be held by non-royal high executives of the state. The revival of the old title jrj-pa.t and its reinterpretation as "coregent" is connected with a sociopolitical process at the transition to the $19^{\text {th }}$ Dynasty, when in the aftermath of the Amarna Period power was passed on to non-royal military aspirants for kingship (Ay, Haremhab, Paramessu and Sethy). ${ }^{28}$ One of these army-based state leaders, Paramessu/Ramesses I, became the founder of the $19^{\text {th }}$ Dynasty. The "civic" origin of the new royal lineage was still emphasized by the third king in line, Ramesses II, who stressed his father's earlier position as a God's Father Beloved of God, jtj-n $\operatorname{Tr} \operatorname{mrj} n \operatorname{Tr}$ (Inscription dédicatoire), and his leading role as the "son of the Regent", Xrd jrj-pa.t (Quban Stela), referring to the time when his father Sethy was still the designated successor to the throne. ${ }^{29}$

While Haremhab and then Ramesside crown princes held the supreme military command, Haremhab's predecessor Ay as well as Paramessu and Sethy headed the specialized forces of the army, bowmen troops and chariotry, as Troop-Commanders (Hrj-pD.t), and Marshals (jmj-rA ssm.wt). ${ }^{30}$ Although Ay maintained close ties to the royal family at Amarna, his military origin might have been a crucial factor in his attaining kingship. Beside their military background, the later founders of the $19^{\text {th }}$ Dynasty were deeply involved in state policy and/or administration, as shown by their non-royal titulatures. Haremhab was Superintendant of the King's Property, jmj-rA pr wr nj nsw, and acted as proxy of the king for all intents and purposes, expressed in the title jdnw nj $\mathrm{Hm}=\mathrm{f} / \mathrm{nj}$ nsw, whereas Paramessu, Sethy and probably also Ay held the rank of a Vizier, thus occupying the highest administrative position.

The uncommon fusion of military and administrative leadership exercised by a very few non-royal title-holders who gained access to kingship at the end of the $18^{\text {th }}$ Dynasty can be observed one more time, at the end of the Ramesside Period (see below $\S 4.4 .1$ ), when a military elite of mostly foreign descent (Panehsi, Pianch, and Herihor) took over political power in the Theban district, claiming control of the Nubian province, the granaries, the royal administration, and of the main cult at Thebes; their exceptional role in the army was characterized by a new fixed military title, HAw.tj, Commander (“of Pharaoh's Troops"), sometimes expanded by the relative clause "who is at the head of the armies of all of Egypt". ${ }^{31}$ Although Ramesses XI was then still on the throne, their concentration of power made these commanders the true rulers of the south. ${ }^{32}$ In spite of a distinctly different

\footnotetext{
${ }^{28}$ W. Helck, Der Einfluß der Militärführer in der 18. ägyptischen Dynastie (Hildesheim: UGAÄ 14, 1964²), 8082, and Gnirs, Militär und Gesellschaft, 100-134.

${ }^{29}$ Inscription dédicatoire in the temple of Sethy I at Abydos, 11. 62-63, KRI II, 329:10-11, RITA II: Translations, 169, RITA II: Notes and Comments, 191-197, and again the Quban Stela, 1. 16, KRI II, 356:1-4, cf. also the socalled Stela-of-400-Years, Cairo Museum JdE 60539, 11. 8-10, KRI II, 288:7-9, RITA II: Translations, 117, RITA II: Notes and Comments, 168f., where Ramesses II reproduces the civic status and filiation of his father Sethy. See also D. O'Connor, "New Kingdom and Third Intermediate Period, 1552-664 BC", in: B.G. Trigger, B.J. Kemp, D. O’Connor and A.B: Lloyd, Ancient Egypt. A Social History (Cambridge, London, New York: 1983), 207, and Gnirs, Militär und Gesellschaft, 117-123.

${ }^{30}$ Gnirs, Militär und Gesellschaft, 67-71, 91-120.

${ }^{31}$ Cf. Gnirs, Militär und Gesellschaft, 57-66.

${ }^{32}$ Gnirs, Militär und Gesellschaft, 62-65, 193-211. For the chronological order of the military commanders resp. the High-Priests of Amun at the end of the $20^{\text {th }}$ and beginning of the $21^{\text {st }}$ Dynasties see K. Jansen-Winkeln, "Das Ende des Neuen Reiches", Z̈̈S 119 (1992), 22-37; id., "Die thebanischen Gründer der 21. Dynastie", GM 157 (1997), 49-74, and J.H. Taylor, "Nodjmet, Payankh and Herihor: The End of the New Kingdom Reconsidered", in: Proceedings of the Seventh International Congress of Egyptologists. Cambridge, 3-9 September 1995, C.J.
} 
historical background, both the late $18^{\text {th }}$ and the end of the $20^{\text {th }}$ Dynasty were characterized by social, bureaucratic and political changes that necessitated an increase of armed control in Egypt or in parts of the country and finally led to a military putsch. At the end of the $18^{\text {th }}$ Dynasty, the army was omnipresent. Abroad, military strategists opposing the diplomatic efforts undertaken by the Amarna court had to cope with a Hittite empire expanding south and threatening city-states allied with Egypt, bringing about a shift of hegemonial power in the ancient Near East. At the end of the $20^{\text {th }}$ Dynasty, Thebes, which first continued to maintain loose contacts with the royal court in the Delta, became the stage for local conflicts between different military parties struggling for political leadership and infiltrating all social and bureaucratic strata. This phase of upheaval fostered the rise of a new political class that originated from foreign mercenaries and elite troops.

\section{§ 3 State bureaucracy and "navy"}

\section{§ 3.1 Military functions and ranks in the "navy"}

Warfare by ship always played an important role in Egypt, in particular during periods of civil strife or war with Nubia. Campaigning in Western Asia sometimes prompted the transportation of troops by ship sent up north along the Levantine coast from the naval base at Perunefer during the $18^{\text {th }}$ Dynasty, later on from the harbour of Piramesse. ${ }^{33}$ When the troops of Thutmose III reached the Euphrates in Syria, they had to build boats in order to be able to cross the river. ${ }^{34}$ In Egypt and Nubia, except for the cataract regions, it was the Nile, the natural link of communication, which permitted a fast mobility of troops.

Beside the term for navigating ship crews, who served on trade or transport vessels often on account of a temple domain, as well as on war ships, ${ }^{35}$ there is only one rank exclusively held by naval officers: Hrj-Xny.t, Commander of a Naval Contingent (lit. "rowers"). ${ }^{36}$ When applied to a war ship, the element Xny.t could be substituted by the name of the military unit or ship, ${ }^{37}$ while the title itself was interchangeable with that of a Standard-Bearer, TAy-sry.t,

Eyre, ed. (Leuven: OLA 82, 1998), 1143-1155. Cf. also A. Niwinski, "Bürgerkrieg, militärischer Staatsstreich und Ausnahmezustand in Ägypten unter Ramses XI.: Ein Versuch neuer Interpretation der alten Quellen”, in: Gegengabe. Festschrift für Emma Brunner-Traut, I. Gamer-Wallert, Ingrid and W. Helck, eds. (Tübingen: 1992), 235-262; id., "Le passage de la XXe à la XXIIe dynastie: chronologie et histoire politique", BIFAO 95 (1995), 329 - 360, and A. Thijs, "The Troubled Careers of Amenhotep and Panehsy: The High Priest of Amun and the Viceroy of Kush under the Last Ramessides", SAK 31 (2003), 289-306.

${ }^{33}$ T. Säve-Söderbergh, The Navy of the Eighteenth Egyptian Dynasty (Uppsala and Leipzig: Uppsala Universitets Årsskrift 6), 37-39. Piramesse is praised as a port city in one of the Ramesside city eulogies, pAnastasi III 7,6, A.H. Gardiner, Late-Egyptian Miscellanies (Brussels: BAe 7, 1937), 28, (hereinafter quoted as Gardiner, LEM), see also C. Ragazzoli, Éloges de la ville en Égypte ancienne. Histoire et littérature (Paris: 2008), 82-84. For movements of troops by sea see Säve-Söderbergh, Navy, 39-70, and cf. D.B. Redford, The Wars in Syria and Palestine of Thutmose III (Leiden etc., Culture and History of the Ancient Near East 16, 2003), 204f., who takes Memphis as the point of departure for the fleet. For Perunefer, see below pp. 11-12. ${ }^{34}$ So-called Gebel Barkal Stela of Thutmose III, now Boston MFA 23.733, 11. 11-12, Urk. IV, 1232:1-6; cf. Klug, Königliche Stelen, 193-208 and 515f. (bibliography).

${ }^{35}$ Säve-Söderbergh, Navy, 85-89. See also S. Bickel, "Commerçants et bateliers au Nouvel Empire. Mode de vie et statut d'un groupe social", in: Le commerce en Égypte ancienne, N. Grimal and B. Menu eds. (Le Caire: BdE 121, 1998), 78f., 157-172, focussing on the crews of cargo ships of public institutions. See also D. Jones, $A$ Glossary of Ancient Eyptian Nautical Titles and Terms (London, New York: Studies in Egyptology, 1988), 9192 Nos. 181-184. In earlier New Kingdom, war ships were technically not distinguished from cargo vessels, see also Redford, The Wars in Syria, 204.

${ }^{36}$ A.R. Schulman, Military Rank, Title, and Organization in the Egyptian New Kingdom (Berlin: MÄS 6, 1964), 56f. $\S \S 136-137$.

${ }^{37} \mathrm{Cf}$. the naval titles born by an officer of the earlier $18^{\text {th }}$ Dynasty, Maienheqau, a battle companion of Thutmose III, P.-M. Chevereau, „Le porte-étendard Maienheqaou“, RdE 47 (1996), 9-28. 
who was carrying the military standard that distinguished an army regiment. ${ }^{38}$ This lower military rank was introduced in the early $18^{\text {th }}$ Dynasty and designated a field-commander of a regiment (SA) of foot soldiers, who himself could lead a naval contingent. ${ }^{39}$ Thus, it seems plausible that army units sent out on ships were organized according to the ranks and functions of land-troops and had the same equipment. That a recruit of a ship is called a "soldier", waw, like the conscripts of land-troops corroborates this idea. ${ }^{40}$ In a Ramesside version of the so-called Satire of Trades, a waw is clearly identified with a member of a naval contingent, obliged to row when he was not fighting. ${ }^{41}$ To move up the career ladder as an ordinary soldier to the rank of a Standard-Bearer and to even higher military positions (TroopCommander, Hrj-pD.t, or Stable-Master, Hrj-jHw) was not uncommon, as biographies and titulatures from the $18^{\text {th }}$ Dynasty show. ${ }^{42}$ In the Ramesside Period, Troop-Commanders serving on cargo (mnSw) ships, for instance, were responsible for the transfer of foreign taxes and tribute to the Residence (see also $\S 4.4 .2$ ). ${ }^{43}$

According to historical records, war ships were used for transportation and as mobile bases for operations on the Nile. ${ }^{44}$ War reliefs from the early $20^{\text {th }}$ Dynasty depict the Egyptian navy involved in sea combats, fighting the so-called Sea Peoples. ${ }^{45}$ It was a common practice in Ancient Egypt to incorporate captured warriors or soldiers into the Egyptian forces. The immigrants, pressed into military service or hired as mercenaries, brought along their own

\footnotetext{
${ }^{38}$ The emblem itself referred to military or martial topics by motives or names. See, for instance, the StandardBearer of a Royal Ship Nebamun, holding the standard of his ship's contingent, in a scene of his tomb (TT 90), while presenting foreign tribute or taxes to Thutmose IV, No. de Garis Davies and Ni. De Garis Davies, The Tombs of Two Officials of Tuthmosis the Fourth (Nos. 75 and 90) (London: TTS 3, 1923), pl. 28.

${ }^{39}$ Helck, Militärführer, 37; R. O. Faulkner, "Egyptian Military Standards", JEA 27 (1941), 13, 17-18; again Säve-Söderbergh, Navy, 79f. and 83, and Schulman, Military Rank, 69-71 §§ 174-180. For Standard-Bearers in the navy see Jones, Nautical Titles, 107-109 Nos. 250-253.

${ }^{40} \mathrm{See}$, for instance, the biography of Ahmose Sa Ibana, Commander of a naval contingent, who started his military career as a waw on a royal ship, biographical inscription in his tomb at El-Kab, 1. 5, Urk. IV, 2:12-13, and C. Barbotin, Âhmosis et le début de la XVIIIe dynastie (Paris: Les Grands Pharaons, 2008), 197-202; cf. Säve-Söderbergh, Navy, 71-75, 78. For this specification referring to ship-crews, -types, and -names, see Jones, Nautical Titles, 72-75 Nos. 94-107 (for Ahmose's title see No. 99).

${ }^{41}$ pBM 10685 rto. 6,5 on the fortunate position of the scribe in comparison to other professions: „For the marine (waw) is worn out, the oar in his hand, the leather (lash) upon his back, and his belly empty of food“, Hieratic Papyri in the British Museum. Third Series. Chester Beratty Gift, A.H. Gardiner ed. (London: 1935), vol. I, Text, 47 , vol. II. Plates, pl. 25-25A; cf. Säve-Söderbergh, Navy, 73.

${ }^{42}$ For examples, see Säve-Söderbergh, Navy, 78-84.

${ }^{43}$ A Troop-Commander of mnSw-ships mentioned in pTurin B vso. 1,7-2,3, a Ramesside model letter, was in charge of a cargo of ointment, diverse army equipment, and wood to be brought to the Residence, probably from a foreign place, Gardiner, LEM, 125:16-126:6, and R.A. Caminos, Late-Egyptian Miscellanies (London: Brown Egyptological Studies 1, 1954), 467-469 (hereinafter qoted as Caminos, LEM). "Troops of cargo ships transfering tribute" for the king to the Residence are listed in a praise of the northern capital on pAnastasi III 7,6, Gardiner, LEM, 28:14-15, Caminos, LEM, 101, and also Ragazzoli, Éloges de la ville, 82-84. Further references are given by Jones, Nautical Titles, 87f., No. 166, and cf. Schulman, Military Rank, $55 \S 133$.

${ }^{44}$ See, for instance, Kamose's report on his campaign against the Hyksos and their allies, W. Helck, HistorischBiographische Texte der 2. Zwischenzeit und neue Texte der 18. Dynastie (Wiesbaden: KÄT, ${ }^{2} 1983$ ), 82-97 No. 119, and Barbotin, Ahmosis, 169-180, or the biography of Ahmose Sa Ibana, Urk. IV, 1-11 (see also above n. 40), and the commentary on these texts by Säve-Söderbergh, Navy, 1-2.

${ }^{45}$ S.C. Heinz, Die Feldzugsdarstellungen des Neuen Reiches. Eine Bildanalyse (Wien: Untersuchungen der Zweigstelle Kairo des Österreichischen Archäologischen Institutes 17, 2001), 305-309 with further bibliography; R. Drews, „Medinet Habu: Oxcarts, Ships and Migration Theories“, JNES 59 (2000), 174-184; P. Grandet, Ramsès III. Histoire d'un Règne (Paris: 1993), 191-201, and B. Cifola, „The Terminology of Ramesses III's Historical Records, with a Formal Analysis of the War Scenes“, Or N.S. 60 (1991), 9-57.
} 
specific armament, techniques in shipbuilding and in boarding manoeuvres. ${ }^{46}$ Large-scale integration of captives of war, however, is not documented before the later New Kingdom, when Egypt was threatened by invasions of foreign migrating peoples. ${ }^{47}$ They were settled in specific strongholds under the control of fortress-commanders and military tribe leaders: ${ }^{48}$

I (i.e., Ramesses III) brought those my sword has spared along as numerous captives bound like birds in front of my horse-team,

….....

I settled their leaders (HA.wtj.w) in fortresses bearing my name

and gave them Troop-Commanders (Hrj.w-pD.t) and Tribe Leaders

(aA.w n(.w) mhw.t).

...."

In this inscription, Ramesses III refers to a practice that was already common in the $19^{\text {th }}$ Dynasty. Individuals bearing the title of a aA nj thr.w, Leader of Mercenaries, and serving the Egyptian army are known from the late $19^{\text {th }}$ Dynasty onwards. In the $20^{\text {th }}$ Dynasty, this military rank could be specified by the name of a fortress, confirming the king's report on the foundation of fortified military settlements. Later on, when these forts became politically and economically more important, their commanders were distinguished as Army-Commanders (jmj-rA mSa) and Commanders (HA.wtj) "at the head of (a chain of) Sherden- resp. MaFortresses", ${ }^{49}$ and sometimes bore even the title of a Director of the Granaries, jmj-rA Sn.wtj, which indicates that at this time military control was closely linked to the control of grain resources. At the end of the New Kingdom, mercenaries' settlements were the breeding

${ }^{46}$ Accounts of the early $18^{\text {th }}$ Dynasty mention foreign types of ships built at the royal dockyard, see pBM 10056 rto. col. 14 1. 5: zktj-boat, pBM 10056 rto. col. 18 1. 4 and pBM 10056 vs. col. 11 1. 2: kftj-ship, S.R.K.

Glanville, „Records of a Royal Dockyard of the Time of Tuthmosis III: Papyrus British Museum 10056. Part I“, ZÄS 66 (1931), 115f., 121 and p. 5*, 8*; id., ,Records of a Royal Dockyard of the Time of Tuthmosis III: Papyrus British Museum 10056. Part II“, Z̈̈S 68 (1932), 14 note 24, and Jones, Nautical Titles, 68f. No. 68, 148 No. 79 and 149 No. 80. Foreign craftsmen appear, for instance, in pBM10056 vs. col. 8 1. 11: Hmww wr J-rATw, "the Chief Craftsman Iratju”, Glanville, Z̈̈S 66 (1931), 120 and p. 7*, and id., Z̈̈S 68 (1932), 27 note 83. For an ancient depiction of a Syrian ship dating to the $18^{\text {th }}$ Dynasty, see N. de Garis Davies, R.O. Faulkner, "A Syrian Trading Venture to Egypt", JEA 33 (1947), 40-46, pl. VIII. On Egypt's "arms trade" during the Late Bronze Age see R.G. Morkot, "War and the Economy: the International 'Arms Trade' in the Late Bronze Age and After", in: Egyptian Stories. A British Egyptological Tribute to Alan B. Lloyd on the Occasion of His Retirement, T. Schneider and K. Szpakowska eds. (Münster: AOAT 347, 2007), 169-195, also Moorey, in: The Social Context, 3f., 6-9, 10-12, esp. 9.

${ }^{47}$ D. O'Connor, “The Nature of Tjemhu (Libyan) Society in the Later New Kingdom”, in: Libya and Egypt c1300-750 BC, A. Leahy ed. (London: 1990), 81-89; Menu, in: La dépendance rurale, 187-209; A. Spalinger, War in Ancient Egypt. The New Kingdom (Malden, Oxford, Carlton: Ancient World at War), 235-263, and J. Degas, „Les pharaons et la mer“, Égypte, Afrique \& Orient 1 (1996), 21-22. Cf. also R. Drews, The End of the Bronze Age. Changes in Warfare and the Catastrophe ca. 1200 B.C. (Princeton: 1993), 48-76 and 97ff., ${ }^{48}$ So-called Historical Section of the Great pHarris I 77,4-5, P. Grandet, Le Papyrus Harris I (BM 9999) (Cairo: BdE 109), vol. 1, 337, 7, and cf. also lines 6,6-9, op.cit., vol. 1, 336f.

${ }^{49}$ These fortified military settlements hosted Libyans $(M)$ or seafaring tribes $\left(\sum r d \mathfrak{r}\right.$. The variant HAw.tj nj nA pD.wt Pr-aA, which is documented for the end of the $20^{\text {th }}$ /beginning of the $21^{\text {th }}$ Dynasty, could be expanded by a relative clause "who was at the head of all the forces of Egypt". The addition suggests that some Commanders of Foreign Troops took control of all Egyptian forces (Panehsi, Pianch, and Herihor), in addition, Pianch and Herihor were also distinguished by the title of a Commander-in-Chief of the Army, jmj-rA mSa wr, while their predecessors only bore the ordinary title of an Army-Leader, jmj-rA mSa, Gnirs, Militär und Gesellschaft, 6265. 
ground for new political elites, the founders of the so-called god's state of Amun in the south and of the Libyan dynasties in the north. ${ }^{50}$

\section{§ 3.2 Naval administration}

How the administration of the navy worked and in which way it interacted with the state's bureaucracy might be deduced from executive titles as well as from administrative documents, so-called ships' logs written on papyrus.

There is only slight evidence for the naval rank of an Admiral of the Royal Fleet, jmj-rA aHa.w (nb.w) nzw. ${ }^{51}$ Acting as a state chief executive rather than a high-ranking officer, an admiral was in charge of the coordination and control not only of war ships, but also of royal transportation and cargo vessels. His scope of responsibilities correlated well with the operating range of a Hrj-Xny.t discussed above, who, on a lower level, commanded war as well as trade or cargo ships. Admirals were in close contact with the royal court and sometimes occupied high positions in the royal administration, as some careers show: Nebamun, Admiral of the Royal Fleet under Thutmose III, bore the title of a Royal Butler, wdpw-nzw, and held the offices of a Director of the King's Bureau, jmj-rA xA nj nzw, and of an Intendant of the Queen's Estate, jmj-rA pr nj Hm.t nzw. ${ }^{22}$ According to "The Duties of the Vizier", the highest official of the state was also in control of the entire fleet: ${ }^{53}$

It is he who assigns ships to everyone to whom a ship needs to be assigned. It is he who dispatches every messenger of the King's House to $[\ldots \ldots \ldots . . . . . .$.$] when the Lord is on campaign ( \mathrm{mSa}$ ).

There has to be reported to him by any council of the vanguard and of the rearguard (=from bow to stern) of the fleet. ${ }^{54}$ It is he who seals every order of $\left[\begin{array}{lllll}\ldots & \ldots & \ldots & \ldots\end{array}\right]$

These remarks imply that the admiralty was a most powerful state function. The man in charge controlled all the royal ships heading to or leaving the Residence or Egypt, decided which vessel was to be entrusted to which state representative or institution and was kept informed about all the activities of the navy. Constant circulation of information between the admiralty, a branch of the royal administration, and the King's House was guaranteed, providing detailed records on the mobilisation of ships, their assignment, destination, manpower, cargo, and on the outcome of their mission. Since the assignment of ships mostly satisfied economic (deliveries of domestic and foreign taxes, exchange of trade goods abroad) and military (transport of troops and armament) interests, besides serving the king and other high state representatives as a fast means of transportation, it seems quite comprehensible that

\footnotetext{
${ }^{50}$ Gnirs, Militär und Gesellschaft, 57-64.

${ }^{51}$ Officials bearing this title are subsumed by Jones, Nautical Titles, 54 Nos. 20-22. The term jmj-rA can be substituted by Hrj, see again Jones, Nautical Titles, 85 Nos. 154-155.

52 Stela with biographical inscription in the tomb of Nebamun, TT 24, 1. 19, Urk. IV, 151:1.

${ }^{53}$ G.P.F. van den Boorn, The Duties of the Vizier. Civil Administration in the Early New Kingdom (London, New York: Studies in Egyptology, 1988), 11.34-35 according to N. de Garis Davies' publication of the inscription in the tomb of Rekhmire, TT 100, The Tomb of Rekh-mi-Re' at Thebes (New York, 1973), pl. XXVI-XXVIII; Urk. IV, 1116:7-12, cf. also Säve-Söderbergh, Navy, 90f.

${ }^{54}$ Related phrases are given in pAnastasi IV 3,6 and 8,7, Gardiner, LEM, 37:15 and 43:7, Caminos, LEM, 138

and 160, although they do not include the term aHaw(.t), ,fleet“, cf. the comments by Glanville, Z̈̈S 68 (1932), 18f., and van den Boorn, Duties of the Vizier, 289 n.1.
} 
it was usually the Vizier as the highest official who filled this important function. ${ }^{55}$ This practice may also suggest that the deployment of ships for military operations was rather limited in comparison to their use for cargo and transportation. In fact, relations between the military organization and the royal fleet were, at times, tensed. Royal decrees from the end of the $18^{\text {th }}$ and the beginning of the $19^{\text {th }}$ Dynasty inform about frequent abuse of power by army officers of different ranks. It seems that it was a common practice among those sent out on royal missions to claim private and public property-including ships and their personnel-for their own purposes, insisting on their special rights as royal agents (see below $\S 4.2$ ). In the so-called Nauri-Decree, Sethy I states: ${ }^{56}$

\author{
His Majesty has decreed that regulation be made for the Temple of \\ Millions of Years (of) the King of Upper- and Lower-Egypt, Menmare, \\ Happy in Abydos, on water and on land, throughout the provinces of \\ the south and north: \\ To prevent interference with anyone belonging to the Memorial \\ Temple of Menmare Happy in Abydos, who is (anywhere) in the whole \\ land, whether man or woman; \\ To prevent interference with any property belonging to this \\ House, which is (anywhere) in the whole land; \\ To pre[vent any per]son belonging to this House being [taken \\ away]: by requisition, by (transfer) from one district to another, by \\ hire-contract, (or) by corvée for ploughing or for harvesting, \\ by any Viceroy, any Troop-Commander, any Mayor, any \\ Agent, or anyone (else) [sent on] a mission to [Ku]sh; \\ to prevent their boat being detained on the water, by any \\ police-check ....
}

Unauthorized detaining of temple transport ships is thematized again in $\S 11$ of the same decree, while $\S \S 25-30$ treat the confiscation of Nubian boats and of their cargo, the "tribute of Kush", as well as the removal of crew members. ${ }^{57}$ Beside the Viceroy of Kush and his military and administrative personnel, largely Fortress-Commanders are addressed as potential offenders of the royal enactment.

The main naval base of the $18^{\text {th }}$ Dynasty was located at Perunefer. It was founded by Thutmose III in the northeastern part of the delta next to the ancient Hyksos capital of Avaris/ Tell el-Dab'a, which was still in use as a royal residence at this time. The site comprised a harbour, storage facilities, a military camp including a military cemetery from the early $18^{\text {th }}$ Dynasty (graves of soldiers and horse burials) ${ }^{58}$ as well as a royal estate. ${ }^{59}$ This was the place from where the Egyptian army departed to Asia and where it landed upon its return back

\footnotetext{
${ }^{55}$ Cf. also A. Graham, „Some Thoughts on the Social Organisation of Dockyards During the New Kingdom“, in: Current Research in Egyptology III. December 2001, R. Ives et al. eds. (Oxford: BAR International Series 1192, 2003), 29f., who points out that similar functions were also carried out by the vizier during the $12^{\text {th }}$ Dynasty. ${ }^{56}$ L1. 29-33, KRI I, 50:12-51:8; RITA Translations I, 44, and RITA Notes and Comments I, 48-55. Cf. $\S \S 1-2$ of the Haremhab-Decree, J.-M. Kruchten, Le décret d'Horemheb. Traduction, commentaire épigraphique, philologique et institutionnel (Brussels: 1981), 28-56. Cf. Säve-Söderbergh, Navy, 91-93, and below. ${ }^{57} \S$ 11: L1. 47-50, KRI I, 53:10-16; §§ 25-30: 11. 82-97, KRI I, 56:6-57:6.

${ }^{58}$ M. Bietak. „The Thutmoside stronghold of Perunefer“, EA 26 (2005), 13-17; id., "Perunefer: The Principal New Kingdom Naval Base”, EA 34 (2009),15-17, and id., „Perunefer: An Update“, EA 35 (2009), 16-17. Until the archaeological investigations by the Austrian Mission at Tell el-Daba, the exact location of Perunefer was debated; some scholars assumed the site close to Memphis, others argued for a place in the Delta, cf. D. G. Jeffreys, "Perunefer: At Memphis or Avaris?", EA 28 (2006), 36-37. The dockyard of Perunefer is mentioned in the records of pBM 10056 vso. 9,11-12, Glanville, Z̈̈S 66 (1931), 120, 7*, see in the following.

${ }^{59}$ Indirect reference to a royal estate at Perunefer is, for instance, given by the title of Superintendant of the King's Estate at Perunefer born by Qenamun, the owner of TT 90, see below pp. 41-42. Glanville, Z̈̈S 68 (1932), 29f., stresses the development of the site from a royal estate including a dockyard and administrative as well as military institutions to a town with its own centre of worship.
} 
home. From Perunefer, triumphal processions of spoils and captives headed southwards to the ancient capital of Memphis. ${ }^{60}$ Linked with this location are some administrative records from the earlier $18^{\text {th }}$ Dynasty: pErmitage 1116 A and B "verso", both mentioning the prenomen of Amenhotep II, Aakheperure, ${ }^{61}$ and pBM 10056, ${ }^{62}$ which refers to a prince Amenhotep, very probably a son of Amenhotep II, ${ }^{63}$ under whose reign Perunefer became an important military and administrative center. From pBM 10056, royal timber accounts, it becomes evident that prince Amenhotep was in charge of timber deliveries for the royal dockyard. ${ }^{64}$

At the very beginning of the $19^{\text {th }}$ Dynasty, Memphis was still the secular capital of Egypt. ${ }^{65}$ Palace accounts from the $2^{\text {nd }}$ and $3^{\text {rd }}$ year of Sethy I suggest that the south quarters of the city were inhabited by middle- and high-rank state servants and officers, among them some high representatives such as the Vizier, ${ }^{66}$ the King's Speaker, ${ }^{67}$ a Lieutenant of the Army (jdnw n $\mathrm{mSa}$ ) in charge of army logistics ${ }^{68}$ or the Troop-Commander of Kush (Hrj-pD.t n KS) ${ }^{69}$. According to the palace timber accounts, many mid-rank military and paramilitary officers, army scribes as well as chariot officers and soldiers of royal ships resided in the southern quarters of Memphis. ${ }^{70}$ In the lists, even the Captain of a Troop-Commander appears. ${ }^{71}$

\footnotetext{
${ }^{60}$ Great Karnak Stela of Amenhotep II, Karnak, $8^{\text {th }}$ pylon, 11.33-35: "Departing of His Majesty from Perunefer, moving down to Mennefer in peace. List of booty ... And the entire land saw the victories of His Majesty ...", Urk. IV, 1315:11-18, and Klug, Königliche Stelen, 260-270 and 502f. (bibliography). See also A. el H. Zayed, „Perou-Nefer: Port de guerre d'Amenophis II“, ASAE 66 (1987), 75-109.

${ }^{61}$ (pErmitage 1116 A vs. 42) W. Golenischeff, Les papyrus hiératiques No. No. 1115, 1116 A et 1116 B de l'Ermitage imperial à St. -Pétersbourg (Petersburg: 1913), pl. 16, and cf. W. Helck, Materialien zur Wirtschaftsgeschichte des Neuen Reiches, part IV. Eigentum und Besitz an verschiedenen Dingen des täglichen Lebens (Wiesbaden: Abhandlungen der geistes- und sozialwissenschaftlichen Klasse der Akademie der Wissenschaften und der Literatur Jahrgang 1963 Nr. 3, 1963), 620-633. (pErmitage 1116 B vs. 56) Golenischeff, Papyrus hiératiques, pl. 27, and cf. W. Helck, Materialien zur Wirtschaftsgeschichte des Neuen Reiches, part V. Eigentum und Besitz an verschiedenen Dingen des täglichen Lebens (Wiesbaden: Abhandlungen der geistes- und sozialwissenschaftlichen Klasse der Akademie der Wissenschaften und der Literatur Jahrgang 1964 Nr. 4, 1965), 890-893. The date of the accounts is also discussed by Glanville, Z̈̈S 66 (1931), 108.

62 (pBM 10056) Glanville, Z̈̈S 66 (1931), 105-121, $1^{*}-8^{*}$, and id., Z̈̈S 68 (1932), 7-41, and cf. W. Helck, Materialien zur Wirtschaftsgeschichte des Neuen Reiches. Part V (Mainz: 1963), 874-890.

${ }^{63}$ For the date of these documents, see Redford, JEA 51 (1965), 108-115.

${ }^{64}$ Cf. Glanville, ZÄS 66 (1931), 106, and Säve-Söderbergh, Navy, 37.
}

${ }^{65}$ Cf. pBN 206 col. I,3 (KRI I, 244:13), pBN 204 col. III,1 (KRI I, 250:12). Cf. also the Abydos Decree of Sethy I at Nauri from his forth year, mentioning Memphis as the place where the king dwelled, 1. 2 of the main text, $\mathrm{K} R I \mathrm{I}, 46: 5$.

${ }^{66}$ Nebamun: pBN 213 vs. I,2 (KRI I, 280:7, and RITA I. Translations, 230). He left a statue at Abydos, now Cairo Museum CGC 1140, and a statue-base at Karnak-North (Karnak TCC.1.), KRI I, 283-284; RITA I. Translations, 231f.; RITA I. Notes and Comments, 186-189. The vizier was already in office at the end of the 18 th Dynasty, as he is mentioned in the tomb of a priest of Sobek, Hatiay, TT 324, from the same period, PM I.12, 395 [7]; N. de Garis Davies, A.H. Gardiner, Seven Private Tombs at Qurnah (London: Mond Excavations at Thebes 2, 1948), 46f., Taf. XXXIII-XXXIV, however, date the tomb into the $20^{\text {th }}$ Dynasty, followed by Kitchen in RITA I. Notes and Comments, 188. For the early date see now E. Hofmann, Bilder im Wandel. Die Kunst der ramessidischen Privatgräber (Mainz: Theben 17, 2004), 18-20.

${ }^{67}$ Nedjem: pBN 210 vso. frag. A,2 (KRI I, 272:5).

${ }^{68} \mathrm{Wa}: \mathrm{pBN} 209$ rto. II,5 (KRI I, 263:6).

${ }^{69}$ Khay: pBN 210 vso. frag. B,4 (KRI I, 272:12), pBN 211 rto. II, 18 (KRI I, 275:8).

${ }^{70} \mathrm{pBN} 209$, passim.

${ }^{71}$ jdnw n mSa, Hrj-pD.t n KS, Hrj-pD.t n pA mSa, pBN 211 rto. I,22 (KRI I, 274:10), pBN 211 rto. II,5 (KRI I, 274:15); wr-nj-mDAj.w, pBN 211 rto. II,16 (KRI I, 275:6), pBN 211 vso. I,6 (KRI I, 276:14); TAj-zry.t, pBN 209 rto. II,13 (KRI I, 263:15), pBN 209 rto. III,5 (KRI I, 264:13), pBN 209 rto. IV,15 (KRI I, 266:15), pBN 209 rto. IV,18 (KRI I, 267:1), pBN 210 rto. frag. A, 1(KRI I, 271:7), pBN 211 rto. I,3 (KRI I, 273:5-6), pBN 211 rto. II,21 (KRI I, 275:13), pBN 211 vso. I,14 (KRI I, 277:4), pBN 211 vso. I,17 (KRI I, 277:6), pBN 211 vso. II,3 (KRI I, 277:13), pBN 213 rto. I,x+3-4 (KRI I, 279:13-14); zS-mSa, pBN 211 rto. I,15 (KRI I, 274:2), pBN 2134 rto. II, $\mathrm{x}+2$ (KRI I, 280:11); Hrj-jHw n jHw n ZtXy a.w.z., pBN 211 vso. III,5 (KRI I, 278:6); znnj, pBN 
Of a slightly later date is the ship's log from pLeiden I 350 verso, which mentions two princes of Ramesses II and a king's daughter. ${ }^{72}$ The papyrus records the distribution of food rations to the ship crew carried out by the Memphite royal administration. Beside the two captains (nfw) and 9-10 temple servants (zmd.t Hw.t-nTr), who probably worked for the temple of Ptah, the crew included eight to nine so-called "trainees/men of the regiment", zDmw-aS/rmT (nj pA) zA, ${ }^{73}$ in other texts referred to as "soldiers", waw (see above $\S$ 3.1). In general, it seems that all of them received the same provisions, i.e., loaves of kyllestisbread ${ }^{74}$ although in one instance "white [triangular] loaves" were given to the soldiers, while the rest of the crew including the two captains was supplied with the regular soldiers' (kyllestis) bread. ${ }^{75}$ In contrast, the rations distributed among the passengers and messengers on board could differ considerably. ${ }^{76}$ The papyrus, listing both jnw-deliveries in aliment by members of the royal court or by military officers and the recipients of these payments, gives an interesting insight into the interplay between the court, the administration and the army: Among the passengers were people from the house of Prince Ramesse, an offspring of Ramesses II, as well as dispatch carriers sent to the King's Son and High-Priest of Ptah at Memphis Khaemwaset (col. III,1; III, 26, col. IV,4). In addition, payments were turned in by Princess Isisnofret, daughter of Merenptah, who, again, might have been the grandson of Ramesses II and the son of the later king Merenptah (col. II,7; IV, 20), ${ }^{77}$ a LieutenantCommander of the Chariotry, jdnw nj tj-n.t Htrj (col. II,3) and two Charioteers, kDn.w (col. II,9 and II,30). They all seem to have been closely linked to the Royal Residence. The identity of some further women and men bringing or receiving provisions must have been well known to the administration, as neither their titles nor their family background were explicitly given. ${ }^{78}$ Part of the group was also a certain pA jmj-rA mSa, "The General": He was father of a Charioteer ${ }^{79}$ and provided as well as received food according to the registers. ${ }^{80}$ In accordance with Janssen, $\mathrm{pA}$ jmj-rA $\mathrm{mSa}$ should be taken as a title rather than as a personal name ${ }^{81}$ given the fact that the phrase is not written with the determinative of the sitting-man otherwise used in all the male names in the text. ${ }^{82}$ In a group of contemporary

209 rto. II,21 (KRI I, 264:7), pBN 209 rto. III,1 (KRI I, 264:9); kDn, pBN 210 rto. frag. A, $\mathrm{x}+3$ (KRI I, 271:9), pBN 211 rto. III,x+2 (KRI I, 276:2), pBN 211 vso. I,19 (KRI I, 277:8), pBN 211 vso. III,7 (KRI I, 278:9); waw, pBN 209 rto. III,18 (KRI I, 265:10), pBN 209 rto. III,20 (KRI I, 265:12); nfw nj Hrj-pD.t n pA mSa, pBN 210 rto. frag. $\mathrm{B}, \mathrm{x}+2$ (KRI I, 271:12).

72 The princes Khaemwaset and Ramesse as well as the princess Isisnofret, J.J. Janssen, Two Ancient Egyptian Ship's Logs. Papyrus Leiden I 350 verso and Papyrus Turin 2008+2016 (Leiden: 1961), 6 .

${ }^{73}$ See the comment by Janssen, Ship's Logs, 6-8. zDmw/rmT (n pA) zA are listed in pLeiden 350 vso. III,17; IV,13; IV, 30; V,4; V,15. This composite term is overtly discussed by Janssen, Ship's Logs, 36f. ad III 17.

Janssen, Ship's Logs, 23f. ad II 1, however, takes the temple servants as the biggest group of the crew to be those obliged to row the ship.

${ }^{74}$ For this kind of bread see again below $\S$ 4.4.3.

${ }^{75}$ See also Janssen, Ship's Logs, 7f.

${ }^{76}$ See, for instance, col. III,10-12, where a scribe receives 50 loaves of big white bread, whereas three imprisoned scribes only got three loaves „to eat"; this shows that some rations were meant, in fact, as payment, others, in contrast, were daily provisions.

${ }^{77}$ For this interpretation see Gnirs, Militär und Gesellschaft, 84f., and cf. H. Sourouzian, Les monuments du roi Merenptah (Mainz: SDAIK 22, 1989), 27f. with n. 128.

${ }^{78}$ A lady Tashuit, col. III,25; Ptahemmenu and Isyra ol. III,29, and a lady Heteri(?), col. IV,17.

${ }^{79} \mathrm{Col}$. I, $\mathrm{x}+15$, where the context is lost, and col. II,9.

${ }^{80}$ Col. III, 8 ; col. IV,33.

${ }^{81}$ Cf. H. Ranke, Die ägyptischen Personennamen, vol. I. Verzeichnis der Namen (Glückstadt: 1935), 100, no. 18.

${ }^{82}$ Janssen, Ship's Logs, 19f. ad col. Ix+15. He also points out that the same expression occurs in letters from the period of Ramesses II, pLeiden I 360 and pLeiden I 368 (J.J. Janssen, „Nine Letters from the Time of Ramses 
letters which might have come from the same archive at Memphis, where also the ship's log must have been filed, pA jmj-rA $\mathrm{mSa}$ is mentioned again as are Prince Khaemwaset, Prince Ramses and Princess Isisnofret. ${ }^{83}$ Since in one of these letters, pLeiden I 368, "the General" is presented as an outstanding authority, we may assume that he was of royal blood. Due to prosopographical evidence, it is not unlikely that he was identical with Prince Merenptah, designated successor to the throne, who was Commander-in-Chief of the Egyptian forces later during the reign of Ramesses II. ${ }^{84}$ Thus, the persons involved in the deliveries to the ships were high members and connexions of the royal family as well as important representatives of the army, and they had direct access to royal administrative and economic institutions. Their base of operation must have been Piramesse (modern Qantir), the new Residence, which was founded early in the $19^{\text {th }}$ Dynasty in the north eastern Delta, where the royal chariotry and other important units of the army were located, ${ }^{85}$ while Memphis was still the administrative center, well linked to the King's House and the palace administration by family ties, as the ship's log and other administrative documents of the period show. According to archaeological evidence, the royal palace was situated in the northern zone of Piramesse as were stables, troop accommodations, and workshops. ${ }^{86}$

\section{$\S 4$ State bureaucracy and army}

\section{$\S$ 4.1 The Royal Guard}

In matters of state security, beside police forces army units were deployed for preparing and securing royal appearances and visits as well as for guaranteeing order throughout the country when royal power was unstable, e.g. during and after the Amarna Period. ${ }^{87}$ From the late $18^{\text {th }}$ Dynasty, a royal decree by king Haremhab reveals interesting insights into political measures aiming at restrictions and patterns of abuse established during the Amarna Period to the detriment of ordinary people. In the context, the army is presented ambiguously, since on the one hand some of its members are accused of wrongfully confiscating resources from the broad population (see below $\S 4.2$ ), on the other hand former soldiers are appointed as priests when temples closed down during the Amarna Period are reopened: ${ }^{88}$

$$
\begin{aligned}
& \text { He (i.e., the king) equipped them (i.e., the temples) with wab-priests } \\
& \text { and lector-priests from the choicest of the army (stp nj mnfy.t), } \\
& \text { assigning to them fields and herds supplied with all (their) equipment. }
\end{aligned}
$$

\footnotetext{
II“, in: OMRO 41 (1960), 40 and 46), where he suggests to interpret it as a designation of the king himself, which, as he admits, cannot be proven by the ship's log, where „The General“" appears as father of a charioteer Ramesnakht.

${ }^{83}$ Janssen, Ship's Logs, 6 and 19f. ad 1x+15.

${ }^{84}$ Gnirs, Militär und Gesellschaft, 84f.

85 J. Dorner, "Zur Lage des Palastes und des Haupttempels der Ramsesstadt", in: Haus und Palast im Alten Ägypten. Internationales Symposium 8. bis 11. April 1992 in Kairo (Wien: Untersuchungen der Zweigstelle Kairo des Österreichischen Archäologischen Institutes 14, 1996), 69-71; E.B. Pusch, „Pi-Ramesse-geliebt-vonAmun, Hauptquartier Deiner Streitwagentruppen": Ägypter und Hethither in der Delta-Residenz der Ramessiden“, in: Pelizaeus-Museum Hildesheim. Die Ägyptische Sammlung (Mainz: Zaberns Bildbände zur Archäologie 12, 1993), 126-143, and id., "Piramesse-Qantir. Residenz, Waffenschmiede und Drehscheibe internationaler Beziehungen", in: Pharao siegt immer. Krieg und Frieden im Alten Ägypten, S. Petschel and M. von Falck eds. (Bönen: 2004), 240-263.

${ }^{86}$ See volume 9 (1999) of Ägypten \& Levante dedicated to different aspects of recent archaeological work at Piramesse, and E.B. Pusch, ,Towards a Map of Piramesse“, EA 14 (1999), 13-15.

${ }^{87}$ R.J. Leprohon, „A Vision Collapsed. Akhenaten's Reforms Viewed through Decrees of Later Reigns“, Amarna Letters 1 (1991), 66-73.

${ }^{88}$ Coronation inscription of Haremhab 1. 25 (Urk. IV, 2120:9-11), cf. Leprohon, Amarna Letters 1 (1991), $71 \mathrm{f}$.
} 
Already earlier in the $18^{\text {th }}$ Dynasty the military was involved in the management of temple personnel, as can be inferred from a wall scene in the tomb of Tjanuni, a Head of Royal Army Scribes and Scribe of Recruits, jmj-rA sS.w-mSa (wr) nj nsw and zS-nfr.w, where the tomb-owner is shown supervising a census of

the army, the wab-priests, the King's labourers and the female servants of the entire country as well as of all the cattle, poultry and small livestock. ${ }^{89}$

Thus, recruit officers were not only responsible for drafting and registering soldiers, but also for administering the lower priestly service and other temple work. In another tomb scene, Tjanuni inspects the recruitment and parades of troops only. ${ }^{90}$ It turns out that Tjanuni also acted as a sS-nfr.w n tA pD.t Pr-aA, "Scribe of Recruits of Pharaoh's Bowmen Troops"which suggests that he conscribed and assembled the Royal Guard at the Residence. ${ }^{91}$

Haremhab's Decree provides some detailed information on the management of the Royal Guard. According to this source, the king temporarily summons up army units at court and installs them as his personal guard. Focussing little on the specific tasks connected with this function, the text emphasizes the recompenses awaiting the officers and soldiers in return for their special duty: ${ }^{92}$

\section{"I (i.e., the king) will maintain the custom of guard[ing] (mk.t) My}

Majesty along every [fi]rst [day] they encircle (pXr) My [Majesty], three times a month: It will be to them like a feast, every man sitting by (his) share of every good thing, consisting of good bread, meat and cakes, (all of it) being from the property of the King. [.........], their voices, in that respect, reaching up to the sky, while praising all good things [......], the commanders of the army (Hrj.w-tp n.w mnfy.t), every leader of the army ( $\mathrm{aA} \mathrm{nb} \mathrm{n}(\mathrm{j}) \mathrm{mSa})$, every soldier, $[\ldots \ldots$ ...] action by throwing (gifts) to them from the window (of appearance) and by calling everybody by his name by the King himself. They will emerge with exaltations and provisions from the property of the King's House. But they will also access (regular) rations account of the (state) granary, every single one of them coming off [loaded with?] barley and emmer. There has not been one

\footnotetext{
${ }^{89}$ An. Brack and Ar. Brack, Das Grab des Tjanuni. Theben Nr. 74 (Mainz: AV 19, 1977), 43f. scene 15, text 34, and pls. 29b, 37. For his titles and epithets see the summary by Brack and Brack, op.cit., 97-99.

${ }^{90}$ Broad Hall, west wall, south, Brack and Brack, Grab des Tjanuni, 37-39, 40-43, scenes 12 and 14, pls. 28a, 29a, 30a, 32-34, 35b.

${ }^{91}$ This unusual title is only documented on funerary equipment from the coffin chamber of Tjanuni's tomb, i.e., on some polychromously painted pottery vessels imitating red granite, Brack and Brack, Grab des Tjanuni, $63 \mathrm{f}$. and 78, find-nos. 1/24-27 and 5/13, texts 77-78, pls. 14b, 46a-c, 64 .

${ }^{2}$ Haremhab's Decree, right side of stela, 11. 8-10, Urk. IV, 2158:3-2159:8, and Kruchten, Le décret d'Horemheb, 162-177. The decree seems to have been published in monumental writing at different important sites of Egypt, the most well-known and -preserved monument being the Karnak stela, but a fragment of the decree was also found at Abydos, now Cairo Museum CG 34162, M.P. Lacau, Stèles du Nouvel Empire, vol. I.2. Catalogue Général des Antiquités Égyptiennes du Musée du Caire Nos 34065-34186 (Cairo: 1926), 203f., and Kruchten, Le décret d'Horemheb, pl. II. The attribution of the stela to Haremhab is based on fragments of the double scene in its upper part, each time showing the king performing an offering before Amun-Re and reproducing Haremhab's royal names, cf. Kruchten, Le décret d'Horemheb, 1f. In his article „Probleme der Zeit Haremhebs“", $C d E 96$ (1973), 265, W. Helck considered the possibility that the stela had originally been erected by Tutanchamun and was later ursurped by Haremhab, like the famous Restauration Stela. In U. Bouriant's tracing of the fragments ("A Thèbes", RecTrav 6 (1885), pl. between p.40 and p. 41), which are today lost, there is, however, no sign of an usurpation, cf. Kruchten, Le décret d'Horemheb, $212 \mathrm{f}$.
} 
who has not had [his] share. [... ...] a DA-wA-tj, ${ }^{93}$ who does for him

the rest. $\left[\begin{array}{llllll}\ldots & \ldots & \ldots & \ldots & \ldots & \ldots\end{array}\right]$ [They will return?] to their towns, without accomplishing the term thereof in days sweating (lit.: giving heat), ${ }^{94}$

as their conscripts $(\mathrm{Xtt})^{95}$ hurry up behind them towards their place, carrying all that they had found there ...".

By taking up the routine of calling officers and soldiers for service at the residence in decades, the king keeps close contact with his troops all over the country and reassures himself of their loyalty, remunerating them with luxury goods at the palace ${ }^{96}$ and granting them a regular income of grain in their home-towns paid by the state granary. The narrative part of the Teaching of King Amenemhet I, which refers to the king's murder by palace guardians, shows how precarious the king's relationship with his guard could be. ${ }^{97}$ Among the conspirers plotting the death of Ramesses III were also high-ranking officers: a TroopCommander of Kush (see also below $\S 4.4 .1$ ) and an Army General, both guaranteeing military support for the planned putsch. The usurpator to the throne seems to have been a Prince Pentawere, backed by his mother; he might as well have held a high military position. ${ }^{98}$

A visual counterpart of the reward scene in the royal decree is found in Haremhab's Memphite tomb. It shows the preparation of a banquet, with the participants feasting on heaps of bread, vegetables, meat, poultry or fish and wine. In another relief, an elderly official is honoured by Haremhab, who is acting as a deputy of the king, bestowing the "gold of honour", ${ }^{99}$ a ceremony usually performed by the king only. ${ }^{100}$ Both these scenes and the

\footnotetext{
${ }^{93}$ This term, followed by the determinative of the landing bird instead of the sitting woman, is attested only one more time in Egyptian sources, pAnastasi IV 12,9, where it is identified with one of the stinging insects that bother an officer of the border-police abroad, cf. J.E. Hoch, Semitic Words in Egyptian Texts of the New Kingdom and Third Intermediate Period (Princeton: 1994), 381f. No. 572. Kruchten, Le décret d'Horemheb, presupposes that in the royal decree, the term characterizes a foreign servant.

${ }^{94}$ Kruchten, Le décret d'Horemheb, 164, translates this passage ,ayant achevé, quant à eux, le(ur) temps complet de garde là-bas sans (s'accorder) (le moindre) repos", disregarding the determinative of the flame in the writing of the term srf.

${ }^{95}$ For this term see the discussion by Kruchten, Le décret d'Horemheb, 172f. ad N).

${ }^{96}$ On this practice see also below $\S$ 4.4.3.

${ }^{97}$ Latest text edition: F. Adrom, Die Lehre des Amenemhet (Brepols: BAeg 19, 2006); translations: R.B.

Parkinson, The Tale of Sinuhe and Other Ancient Egyptian Poems 1940-1640 BC (Oxford, New York: Oxford World's Classics, 1997), 203-211, or G. Burkard, "'Als Gott erschienen spricht er': Die Lehre des Amenemhet als postumes Vermächtnis", in: Literatur und Politik im pharaonischen und ptolemäischen Ägypten (Cairo: BdE 127, 1999), 153-173.

${ }^{98}$ Turin Judicial Papyrus col. IV, 2 (mentions Ty, the mother of the prince, who was accused herself), KRI V, 352:3, RITA Translations V, 298; Pentawere appears in col. V,4, among other delinquents who killed themselves after the verdict of the court, KRI V, 357:12, RITA Translations V, 300, and again in col V,7: "Pentawere, who was the one to whom was given the other name (as usurpator probably his throne-name). He was brought in because of his having made alliance $<$ with $>$ Ty, his mother, when she had plotted these matters together with the women of the harim, raising rebellion against his Lord," KRI V, 358:9-12, RITA Translations V, 301. Cf. P. Vernus, Affaires et scandales sous les Ramsès. La crise des valeurs dans l'Égypte du Nouvel Empire (Paris: 1993), 147-150, and G. Meurer, "'Wer etwas Schlechtes sagen wird, indem er ihre Majestät lästert, der wird sterben'. Wie verwundbar waren das ägyptische Königtum bzw. der einzelne Herrscher?”, in: Jerusalem Studies in Egyptology, I. Shirun-Grumach eds (Wiesbaden: ÄAT 40, 1998), 307-321. For a presumed identification of Pentawere with Sethherkhepeshef I depicted in the princely processions in the the temple of Ramesses III at Medinet Habu see C. Leblanc, "La véritable identité de Pentaouret, le prince "maudit"”, RdE 52 (2001), 151-170. According to inscriptions in his tomb, QV 43, his full military rank was kDn tpj $\mathrm{nj} \mathrm{Hm=f} \mathrm{n}$
}

pA jHw aA nj «sr-MAa.t-Ra mrj-Jmn n Xnw Raw-mss HkA-Jwnw, First Royal Charioteer of the Great Stable of Ramesses III in the Residence of Ramesses III, he was, thus, officer of the Royal Chariotry at the Residence, cf. Gnirs, Militär und Gesellschaft, 89.

${ }^{99}$ G. Th. Martin, The Memphite Tomb of Horemheb Commander-in-Chief of Tut'ankhamun. Part I. The Reliefs, Inscriptions, and Commentary (London: EES 55, 1989), 38-43 Scenes [18-21], pls. 30 above, 31, 32 above and 
mentioned paragraph in Haremhab's Decree can be interpreted as expressions of a deep alliance between the monarchy and the army after the Amarna age.

According to tomb scenes from El-Amarna, ${ }^{101}$ Akhenaten's palace guard accompanied the king and royal relatives whenever they left the palace. Scenes in the tomb of Panehsy show that the guard consisted of soldiers and of mDAj.w-police troops: While policemen are next to the royal chariots and their escort, standard-bearers and foreign mercenaries are at the head and at each side of the parade (tomb of Panehsy). ${ }^{102}$ Another Amarna tomb scene suggests that the police was, in fact, subject to military administration, whose head was called a "Commander of the Army, who is present in front of His Majesty" (HA.wtj nj mSa ntj $\mathrm{aHa}(\mathrm{w}) \mathrm{m}-\mathrm{bAH} \mathrm{Hm=f)} \mathrm{and} \mathrm{ranked} \mathrm{among} \mathrm{the} \mathrm{palace} \mathrm{officials} \mathrm{(sr.w} \mathrm{aA.w} \mathrm{n(.w)} \mathrm{Pr-aA}$

a.w.s.), following the Vizier. ${ }^{103}$ This subordination is also thematized in the Duties of the Vizier: ${ }^{104}$

It is he who assembles the army contingent that escorts the Lord, when [sailing downstream] and upstream. It is he who organizes the remainder (of the guard) in the Southern City and in the Residence

33, from blocks found in the first courtyard of the tomb. Banquets were also catered for the army and the chariotry returning back home from a campaign abroad, see pAnastasi IV 13,8-17,9, Gardiner, LEM, 49-54; Caminos, LEM, 198-219, cf. also Gnirs and Loprieno, in: Militärgeschichte des pharaonischen Ägypten, $284 \mathrm{f}$. ${ }^{100}$ Cf. P. Vomberg, Das Erscheinungsfenster innerhalb der amarnazeitlichen Palastarchitektur. HerkunftEntwicklung - Fortleben (Wiesbaden: Philippika 4, 2004), 218-240, 243-245, figs. 126-141, 147-148. Textual references are given in the fictional letter of pAnastasi I 14,1-2; 15,1, H.W. Fischer-Elfert, Die Satirische Streitschrift des Papyrus Anastasi I. Textzusammenstellung (Wiesbaden: KÄT, 1992²), 108f., 113; H.W. FischerElfert, Die Satirische Streitschrift des Papyrus Anastasi I. Übersetzung und Kommentar (Wiesbaden: ÄA 44, 1986), 122-124 and 134.

${ }^{101}$ See, above all, the scenes from the tomb of Mahu, commander of the mDAj.w-police in Amarna $(\mathrm{Hrj}-$ mDAj.w n Ax.t-Jtn), tomb No. 9, N. de Garis Davies, The Rock Tombs of El Amarna. Part IV. Tombs of Penthu, Mahu, and Others (London: ArchSurv 16, 1906), 12-18, pls. 16-29, esp. 20-22 (escorting the royal chariotry towards the gate of the city or palace fortification wall), 24 (surveying trade at a military tower and income of goods), 25-26 (handing over of emprisoned foreigners to the Vizier, other high officials and an army commander at the entrance of a monumental building); the tomb of Panehsy, First Servant of Aten, first hall, N. de Garis Davies, The Rock Tombs of El Amarna. Part II. The Tombs of Panehesy and Meryra II (London: ArchSurv 14, 1905), 17-19, pls. 13-18 (royal drive out on east wall and visit to the temple on west wall), and the tomb of Merira, Great of Seers of Aten in the temple of Aten at Amarna, tomb No. 4, first hall, N. de Garis Davies, The Rock Tombs of El Amarna. Part I. The Tomb of Meryra (London: ArchSurv 13, 1903), 23-28, pls. 10, 15-20 (royal excursion to the temple on west wall) and p. 32f., pls. 25-26 (royal visit at the temple with excort waiting outside the temple gate consisting of standard- and fan-bearers, soldiers and charioteers as well as police, on east wall).

102 Davies, El Amarna II, pl. 13. The army as royal guard screening the king on journeys from the rest of the world is also described in the so-called Tempest Stela of king Ahmose from the early $18^{\text {th }}$ Dynasty: „His Majesty descended to his ship, followed by his council, [his] army screening (him) [on the] east and west side, as there was no cover (left) on it after god's might had appeared“", Ll. 10-12 on verso, 11. 12-14 on recto, W. Helck, Historisch-biographische Texte der 2. Zwischenzeit und neue Texte der 18. Dynastie (Wiesbaden: KÄT, 1983²), 107; M.H. Wiener and James P. Allen, „Separate Lives: The Ahmose Tempest Stela and the Theran Eruption“, JNES 57 (1998), 1-28, Fig. 1a-b, and Barbotin, Ahmosis, 215-220. For the composition of the palace guard in the late Middle Kingdom see S. Quirke, The Administration of Egypt in the Late Middle Kingdom. The Hieratic Documents (Malden: 1990), 81-84, where the function of security police was filled in by imy.w-xt sA.w-pr.w, and the highest military commanders close to the king were, besides a general, jmj-rA mSa, the ATw.w nj T.t-HqA, „Commanders of the Ruler's Crew“ opposed to those related to Egyptian towns, the ATw.w aA.w nj nw.t.

${ }^{103}$ Davies, Rock Tombs IV, pl. 26, inferior register, see the previous note.

${ }^{104}$ Van den Boorn, Duties of the Vizier, 218-228, and Urk. IV, 1112:12-16. 
according to what have been said in the King's House. To him are brought the Captain of the Ruler $<$ 's Crew $>$ set at his office ${ }^{105}$ and the headquarters of the army in order that they be given the instruction of the army.

This hierarchical structure reflected in the Amarna tomb scene is echoed in the mourning procession on the famous Berlin Trauerrelief from the time of Tutankhamun, where the "Royal Scribe, Regent and Army General", i.e., the Commander-in-Chief of the Army and designee to the throne (see above $\S 2$ ), comes first, followed by the two Viziers, while the rest of the group consisted of other high state representatives, among them the Intendant of the King's Estate, the Royal Treasurer and the Director of the Treasury, a further Army General, the Governor of Memphis and the highest local priests. It has been suggested that the prominent figure of the Regent and Commander-in-Chief of the Army be identified with Haremhab, as he held this extraordinary position at the court of Tutankhamun. ${ }^{106}$ These references again support the suggestion $(\S 2)$ that the supreme command of the army was located at the center of the state, i.e., at court, and that it was closely related to other departments of the royal administration.

Since Horemhab's Decree focuses on change rather than on continuity of practices, it seems likely that the royal guard at Amarna had served on a permanent basis, in contrast to the rotation system reintroduced by Haremhab, according to which officers and soldiers were drafted from different locations for a limited period of time. ${ }^{107}$ This rotation might have been routine already during the earlier $18^{\text {th }}$ Dynasty, ${ }^{108}$ as J.-M. Kruchten pointed out, referring to an inscription of the Lieutenant of the Army Amenemheb from the time of Amenhotep II: ${ }^{109}$

Ushering the heads of the army and the soldiers of the forces to the Palace, L.P.H., to let them feed on bread, beer, beef, wine, cakes, all kinds of good vegetables and all the good things which delight the heart in [front] of [th] is good god.

\section{§ 4.2 Abuse of military authority}

Abuse of authority by members of the army against the broader population and economic institutions must have been a constant nuisance in Ancient Egypt. In Haremhab's Decree, the two Lieutenants of the Army (see again below $\S 4.3$ ) are once accused of confiscating private boats for the use of the royal production center (wab.wt s.wt Pr-aA), in another case, the two "army regiments" located on the countryside in the north and in the south are criticized for wrongfully taking cattle skins from the population, which, instead, ought to be collected

${ }^{105}$ Van den Boorn, Duties of the Vizier, 218 b) and 224-226, understands the verb-form Htp as a corrupt writing for Tt, „naval crew“, in the title Atw nj Tt HqA, a high military rank of the Late Middle Kingdom, see Berlev, $R d E 23$ (1971), 31-48, and already above $\S 1$.

${ }^{106}$ Relief Berlin No. 12411, A. Erman, Z̈̈S 33 (1895), 18-24, pls. I-II, and A.R. Schulman, „The ,Berlin Trauerrelief' (No 12411) and Some Officials of Tutankhamun and Ay“, JARCE 4 (1965), 55-68, pl. XXX. Cf. also J. Berlandini-Keller, „Cortège funéraire de la fin XVIII ${ }^{\mathrm{e}}$ dynastie à Saqqara. Staatliche Museen Munich ÄS 7127“, BSFE 134 (1995), 30-49.

${ }^{107}$ During the Middle Kingdom, the Royal Guard was part of the king's entourage, cf. O. Berlev, Obščestvennye Otnošenija v Egipte epochi Srednego Carstva (Moscow: 1978), 206f., and Chevereau, RdE 42 (1991), 71.

${ }^{108}$ Kruchten, Le décret d'Horemheb, 177.

109 Tomb of Amenemheb, TT 85, registration and provisioning of troops on southern east wall of broad hall, PM I. $^{2} 1$, 170f. (2), Urk. IV , 911:5-9; there is a copy of the scene and text in TT 88, the tomb of Pehsuher, who was a successor of Amenemheb: PM I. ${ }^{2} 1,180$ (1); Urk. IV, 1459:19-1460:3; on the correspondences of the scenes and their location in each respective tomb see S. Eisermann, "Die Gräber des Imenemheb und des Pehsucher Vorbild und Kopie?”, in: Thebanische Beamtennekropolen. Neue Perspektiven archäologischer Forschung. Internationales Symposion Heidelberg 9.-13.6.1993, J. Assmann et al. eds. (Heidelberg: SAGA 12, 1995), 7477. For the contents of the scenes see also below pp.21-22. 
only by the Overseer of Cattle. ${ }^{110}$ On the one hand, the royal resolution was meant to protect ordinary people from abuse of power; on the other hand, it defended the official interest of collecting taxes in full and in due time. A short time later, Sethy I enacted the Nauri-Decree to the benefit of the domain of his "Mansion of Millions of Years" at Abydos"111 in order to prevent state representatives from interfering with any kind of personnel and property attached to the royal temple, which apparently owned fields, cattle, cargo ships, fish pools and marshes in the south and was one of the main benefitters of the so-called Nubian tribute (see also above $\S 3.2$ and below $\S 4.4 .1$ ). Besides officials on missions to Nubia, the target group of the verdict was imperial authorities such as the Viceroy of Kush, Commanders of Troops and Fortresses, Stablemasters or Charioteers. ${ }^{12}$ It was strictly forbidden to draft people belonging to the temple to any kind of state labour

by requisition from one district to another, by (hire-)contract, by corvée for ploughing or by corvée for harvesting, ${ }^{113}$

frequently practised by royal agents and military executive personnel used to organize and control man-power and other resources. To be in charge of a royal mission seems to have been a good excuse for administrative or economic interventions such as the confiscation of temple ships. According to the inscription, the boilerplate was then:

I will take it (i.e., the ship) compulsorily from it (i.e., the temple) for any mission of Pharaoh, L.P.H.! ${ }^{114}$

In administrative documents, abuse of military power is often an issue. In an official letter from the early $19^{\text {th }}$ Dynasty, pCairo 58054, the Standard-Bearer of the Squad "The-Bull-is-inNubia" reprimands one of his inferiors, a soldier and Chief of Impressment, aA nj Stt, ${ }^{115}$ for having ignored written orders and unlawfully apprehended service personnel. ${ }^{116}$ In another letter, the same Standard-Bearer ${ }^{117}$ opposes Garrison Captains, Hrj.w-jway.t, for having prevented people ${ }^{118}$ from doing their labour for "the god of Tell el-Balamun (Jw nj Jmn)" and attracting criticism by the high royal administration (nA nj sr.w nj Pr-aA a.w.s.). Offences of that kind could be severely punished, as a Ramesside model letter suggests. It stigmatizes the unauthorized recruitment of corvée workers by a scribe of the High-Priest of

\footnotetext{
${ }^{110} \S 1$ of the decree, 11. 13-16, Urk. 2143:15-2144:17, and $\S 4,11.24-27$, Urk. IV, 2147:16-2149:13, see also Kruchten, Le décret d'Horemheb, 28-47 and 80-95.

${ }^{111}$ KRI I, 45:6-58:15; RITA Translations I, 38-50, and RITA Notes and Comments I, 48-55 with bibliography, see also the translation by B.G. Davies, Egyptian Historical Inscriptions of the Nineteenth Dynasty (Jonsered: DMA 2, 1997), 277-308. Cf. Leprohon, Amarna Letters 1 (1991), 73; D.A. Warburton, State and Economy in Ancient Egypt. Fiscal Vocabulary of the New Kingdom (Freiburg, Göttingen: OBO 151, 1997), 190-193.

${ }^{112}$ R. Morkot, „The Economy of Nubia in the New Kingdom“, in: Actes de la VIIIe conférence internationale des études Nubiennes Lille 11-17 Septembre 1994, vol. I. Communications principales (Lille: CRIPEL 17, 1995), 177. See also below $\S 4.4 .1$.

${ }^{113}$ L.32, KRI I, 51:5-7: ... r tm [rdj.t j.TAj.tw rm]T nb nj pr pn m kfaw m w n w m bA-rA-tj m bHw nj skA m bHw n awAy ....

${ }^{114}$ L. 49: KRI I, 53:13-14.

${ }^{115} \mathrm{Cf}$. the addressee of letter pCairo 58055 1.1, A. el-M. Bakir, Egyptian Epistolography from the Eighteenth to the Twenty-First Dynasty (Cairo: BdE 48, 1970), pls.3-4, and cf. E. Wente, Letters from Ancient Egypt, edited by E.S. Meltzer (Atlanta: Writings from the Ancient World, 1990), 115 No. 135.

${ }^{116}$ Bakir, Egyptian Epistolography, pl. 2, and Wente, Letters, 115 No. 134.

${ }^{117}$ pCairo 58053, Bakir, Egyptian Epistolography, pl. 1, and Wente, Letters, 114f.

118 The term appears twice, in 1.2 and 1.8 , both times the determinative is the sitting woman omitting the sitting man; if the writing is correct, this might suggest that the people involved were actually women.
} 
Ptah, which, according to the text, could trigger the death penalty, and accuses the addressee of having overestimated his own humble position in project management: ${ }^{119}$
As for a Chariot Shield-Bearer (qraj) of His Majesty L.P.H., a Stable-
Master (Hrj-jHw) (or) a Retainer (Smsw) of Pharaoh L.P.H., he
moves (thm) the masses of corvée-workers who are at Memphis. It is
not you who gives orders to them <in> the house of Thot, your god.
….....
But you are a miserable little man, whose actions are all examined- how happy you are when only your eye saw them!

Other documents suggest that recruiting manpower from temple and royal estates in order to serve the interests of the army must have been a constant annoyance. ${ }^{120}$ Breaches of authority could, however, also strike the military organization: A letter by the Head of the RecordKeepers of the King's Treasury from the time of Ramesses II objects that the Steward of the royal temple at Western Thebes (ie., the Ramesseum) had seized fields initially awarded to the Stable-Master (Hrj-jHw) of the Great Royal Stable at Piramesse and orders the latter's immediate reimbursement. The text also shows that the transaction should be reported to the (Royal) Granary and implies that this institution worked side by side with the Royal Treasury and that both offices maintained close relationships with the military organization. ${ }^{121}$

In general, it seems that at the management level economic institutions and army were well connected. Both sides profited from this relationship: while the army received supplies and arable land from the state departments, these, in return, had access to military manpower for public projects and relied on army contingents and military expertise on missions abroad. Close cooperation could, however, also trigger problems of management, as competences and hierarchies were not clearly defined according to professional domains. Abuse of authority was, thus, a systemic disease, deeply rooted in the fabric of ancient Egyptian bureaucracy.

\section{§ 4.3 Military management, workforces, and army logistics}

Due to its relatively free access to manpower, the military organization played an important role in public projects ${ }^{122}$ such as monumental constructions, transportation of stone or field labour during the summer period ${ }^{123}$. The regular term for troops of workmen was "army", $\mathrm{mSa} ;{ }^{124}$ by analogy, their commander was an Army General, jmj-rA mSa, sometimes also

\footnotetext{
119 pTurin A vso. 4,1-3 and 4,5, Gardiner, LEM, 123f., Caminos, LEM, 454-456 and 508-510. For this passage see also A.M. Gnirs, „In the King's House: Audiences and Receptions at Court“, in: Egyptian Royal Residences - Fourth Symposium on Egyptian Royal Ideology, The British Museum, 1-5 June 2004, R. Gundlach and J.H. Taylor eds. (Wiesbaden: KSG 4.1, 2009), 40f., and Gnirs and Loprieno, in: Ägyptische Militärgeschichte, 283. ${ }^{120}$ In a letter of complaint from pAnastasi VI (7-50, Gardiner, LEM, 73-76, Caminos, LEM, 280-293), an Overseer of the Estate of a sanctuary is said to „have fled“ his working place for fear of being recruited by those „seizing soldiers (j.TAj.w waw.w, 1. 41-42)“. A letter dispatched to a Scribe of the Armoury of Pharao L.P.H. by an inferior on pBologna 1094 4,9-5,8, Gardiner, $L E M$, 5, Caminos, LEM, 16f., refers to the recruitment of three boys passed over by the vizier to the temple of king Merenptah at Memphis to become wab-priests, but who were, instead, brought north - to the fortress of Tjaru, where the armoury was located? - to become soldiers (1. 5,2-5,4); the Scribe of the Armoury was, therefore, asked to investigate the case.

121 pSallier I 11. 9,1-9,9, Gardiner, LEM, 87, Caminos, LEM, 326-328.

122 cf. also Gnirs and Loprieno, in: Ägyptische Militärgeschichte, 282-282.

${ }^{123}$ Cf. pAnastasi V, 7,5-6 (=pChester Beatty V rto. 6,7sq.), Gardiner, LEM, 59, Caminos, LEM, 230, a text from the genre of the so-called satire of trades, where it is said that retainers (Smsw.w) of the army were branded when emitted to the fields.

${ }^{124}$ Cf. L.-A. Christophe, „La stèle de l'an III de Ramsès IV au Ouadi Hammamat (No. 12)“, BIFAO 48 (1948), 32-34, and C. Vandersleyen, Les guerres d'Amosis. Fondateur de la XVIII Dynastie (Brussels: 1971), $180-182$.
} 
called "Army General of Royal Monuments", jmj-rA mSa m mnw nj nb-tA.wj. ${ }^{125}$ Scribes of Recruits (sS.w-nfr.w) or Captains of the Desert Police (wr.w-mDAj.w) often carried out this function in combination with that of a Supervisor of Constructions, jmj-r kA.wt. ${ }^{126}$ In a long biographical inscription, the Scribe of Recruits Amenhotep Sa Hapu recounts a challenging building project under his control, the manufacturing and erecting of a colossal statue in one of the Theban temples built by his king, Amenhotep III: ${ }^{127}$

My Lord appointed me Supervisor of Constructions, And I made the name of the King endure eternally, not by imitating what was achieved before, but by providing for him a sandstone quarry -(for) he is Atum's heir.

I did (it) according to my heart's wish, convoying his effigy to that huge temple of his, (built of) all (kind) of hard stone like heaven. …....

I directed works on his statue, big and wide, and high to its pillar, its splendor outshines the pylon, its length is 40 cubits, from the precious sandstone quarry to both sides of Atum.

I manufactured (for it) ships of eight and brought it down the river, being (now) installed in his great temple, firm as heaven - those among you who will follow us, will be my witnesses!

The entire army as one man followed my command, they did (their duty) joyously, their hearts happy, while praising and venerating the Good God. When they moored at Thebes rejoicing, the monument was erected on its place for the time after eternity.

According to his biography, Amenhotep Sa Hapu was responsible for each step of the building process: finding the proper sandstone quarry, directing the stonemasons work, organizing and supervising the transport of the monument on the river and to the temple where it should be erected as well as installing the statue at its place of final destination. For the enterprise, a large workforce was necessary. In a second biographical inscription, Amenhotep speaks even of two colossal statues that he had moved from a quarry in the North to Western Thebes. ${ }^{128}$

\footnotetext{
${ }^{125}$ The title is, for instance, held by Hapy, an officer of the Royal Guard, under Sethy I, rock stela at East Silsila, KRI I, 61:12-13, RITA Translations I, 53.

${ }^{126}$ See Gnirs, Militär und Gesellschaft, 37, 141-159.

127 Statue from Karnak, now Cairo Museum CGC 583, L. Borchardt, Statuen und Statuetten von Königen und Privatleuten im Museum von Kairo Nr. 1-1294, part II. Text und Tafeln zu Nr. 381-653. Catalogue Général des Antiquités Égyptiennes du Musée du Caire Nos 1-1294 (Berlin: 1925), 134-139, pl. 100 (below), 101-104, 11. 15-17; Urk. IV, 1822:10-1823:12, and see the translation by A. Varille, Inscriptions concernant l'architecte Amenhotep fils de Hapou (Cairo: BdE 44: 1968), texte No. 11; cf. also Gnirs, Militär und Gesellschaft, 142-144. ${ }^{128}$ Statue from the $10^{\text {th }}$ pylon at Karnak, now Cairo Museum JdE 44681, 11. 3-12, M.G. Legrain, “Au Pylône d'Harmhabi à Karnak (X Pylône)”, ASAE 14 (1914), 17f., pl. III (JdE 44861); Die Hauptwerke im Ägyptischen Museum Kairo (Mainz: 1986), No. 148, fig. 148, and Urk. IV, 1833:1-6. Among others, R. Stadelmann, "Die Herkunft der Memnon-Kolosse: Heliopolis oder Aswan?", MDAIK 40 (1984), 291-296, identifies the two mentioned statues with the so-called Memnon's colossi still in situ in front of the great temple of Amenhotep III on the west bank of Thebes; differently D.D. Klemm, R. Klemm and L. Steclaci, "Die pharaonischen
} 
Some tombs of the earlier $18^{\text {th }}$ Dynasty at Thebes depict the provisioning of soldiers and officers (see also below $\S 4.4 .3$ ). Most often, the scene is set in the broader military context of recruitment and exercises. ${ }^{129}$ According to the Decree of King Haremhab, army provisions were distributed and portioned by a logistics office headed by two Lieutenants of the Army (jdnw 2 nj pA mSa), ${ }^{130}$ after supplies had been granted by the Royal Granaries and related economic institutions. The catering scene in the tomb of Userhat, a Scribe of Bread Accounts, ${ }^{131}$ shows soldiers standing in line and receiving their rations of bread, as well as the higher charges of the army squatting on the floor or, depending on their rank, sitting on mats and having food and drinks. ${ }^{132}$ Thus, as a subordinate to the Royal Granary, the tomb-owner was involved in the process of food distribution at garrisons and military bases. A catering scene in the tomb of the jdnw nj pA mSa Amenemheb (TT 85) suggests that his office must have closely cooperated with that of army logistics: the tomb-owner, assisted by a personal scribe, supervises the distribution of food in company of the Director of the Royal Granaries and Accountant of (the ingredients) of Brewing and Baking, Hsb pfsw, ${ }^{133}$ who was responsible for delivering the exact quantities of grain to the bakery and brewery, where bread and beer for the soldiers were produced. ${ }^{134}$ Both tombs display close ties between the Royal Granary and the army.

According to his biography, Djehutimose, Royal Herald under Thutmose III, was deployed as a wp.wtj-nsw on a military mission to Nubia at a time, when he held the office of the Director of the Royal Granaries, in order to

nourish (snm) the [...] of the king, the [a]rmy, the entourage (lit.:

"friends") and the magistrate, to levy the army (sHwj) and to conscript the recruits (snhj DAm.w), and in order to do what is to be done in the whole land and to render every man satisfied with his payment (Sb.w).

${ }^{135}$

\footnotetext{
Steinbrüche des silifizierten Sandsteins in Ägypten und die Herkunft der Memnon-Kolosse”, MDAIK 40 (1984), 207-220.

${ }^{129}$ TT 85, tomb of the Lieutenant of the Army Amenemheb from the time of Thutmose III/Amenhotep II, broad hall, east wall, south, W. Wreszinksi, Atlas zur altägyptischen Kulturgeschichte, vol. I. Privatgräber des Neuen Reiches (Leipzig: 1923), 94a-b; TT 88, tomb of the Lieutenant of the Army Pehsuher from the time of Amenhotep II, broad hall, east wall, south, Wreszinksi, Atlas I, 279; TT 78, tomb of the Royal Scribe of Recruits Horemheb from the time of Thutmose IV/Amenhotep III, An. Brack and Ar. Brack, Das Grab des Haremheb. Theben Nr. 78 (Mainz: AV 35, 1980), 30-36, pls. 38-43, figs. 14-18).

${ }^{130}$ Ll. 15 and 20, Urk. IV, 2144:11 and 2146:10, cf. Kruchten, Le Décret d'Horemheb, 45f.

${ }^{131}$ TT 56, the tomb of the Scribe of Bread Accounts of Upper- and Lower-Egypt Userhat from the time of Amenhotep II, C. Beinlich-Seeber and A.Gh. Shedid, Das Grab des Userhat (TT 56) (Mainz: AV50, 1987), 6469 , pls. 4, 5, 29, figs. 24-26. To the depiction of provisioning a genre scene is added, showing soldiers being treated by barbers. As the tomb-owner was a Bread Accountant, his tomb decoration does not include any recruitment scenes.

${ }^{132}$ A similar composition characterizes the catering scene in the tomb of Horemheb, TT 78 (see above n. 129), showing ordinary soldiers approaching a gate where they receive their bread rations, while army commanders take their meals seated, forming groups and feasting on different sorts of food according to their ranks.

${ }^{133}$ Urk. IV, 911:13-14, 912:6.

${ }^{134}$ Cf. Beinlich-Seeber and Shedid, Grab des Userhat, 104f., who take the Director of Granaries as the one who calculates the rations of bread and beer to be delivered.

${ }^{135}$ H. Selim, „Two Unpublished Eighteenth Dynasty Stelae from the Reign of Thutmoses III at Cairo Museum TN. 20.3.25.3 and TN. 21.3.25.14 (Plates I-II)“, in: Studies in Honor of Ali Radwan vol. II (Cairo: Supplément aux Annales du Service des Antiquités de 1'Égypte. Cahier No. 34, 2005), 333-337, fig. 2, pl. II.
} 
In this inscription, a former Director of the Royal Granaries claims of having been responsible for supplying a campaigning army abroad, but also for functions usually assigned to the Lieutenants of the Army, such as the recruting and inspecting of the troops.

A Ramesside model letter on pSallier IV may offer further insight on the relational hierarchies between the state department and the military, as it explicitly mentions a Royal Scribe and Overseer of the Royal Granaries as the superior (ntj r-HA.t) of a Lieutenant of the Army entrusted with the sending of good quality grain to a state institution, probably the "Mansion of Millions of Years" of king Merenptah at Western Thebes. ${ }^{136}$ The author of the letter, an Intendant of the Estate of this temple, appears as a Lieutenant's supervisor reminding him of the orders he had to carry out. Two facts can be concluded from this document: 1) The Lieutenant was subordinated to both offices of the same establishment, the granary and the estate of the temple, while the first seems to be subordinated to the second. 2) Since the temple administration acted by order of the king himself, its representatives were in a position that could overrule hierarchies at work in other institutions such as the army. In this case, the channels of communication might have run directly from the King's House to the administration of the Theban temple of Merenptah and from their to the office of army logistics.

pAnastasi I, a long fictive letter from the $19^{\text {th }}$ Dynasty presenting a rhetorical dispute between two military men, also dwells on the qualifications needed by a Scribe of Recruits in charge of building projects, e.g. the competence to determine the exact number of men needed to erect a colossal statue on its spot and the right quantity of provisions for the workers. ${ }^{137}$ This is also a topic treated in an inscription of Sethy I, who is said to have sent out "soldiers of the army, one thousand men", to the sandstone quarries of Gebel es-Silsila in order to transport royal monuments down the river to Thebes, having provided them satisfactorily with

ointment, beef, onions(?), and plenty of vegetables. Each man
amongst them (received) 20 Deben (about 1'800 g) of bread twice a
day, bundles of vegetables, roasted meat, and two sacks of grain each
month. ${ }^{138}$

In general, work forces were supplied by representatives of the Royal Granary and the Treasury as well as by local authorities of the city or district where a construction project took place. In a letter on pTurin B, orders were given to move three large barges full of corn and ointment, the provisions for a big workforce of an unspecified number, at a temple construction site. Workmen were supervised by three companies of soldiers (i.e., $600 \mathrm{men}$ ), which indicates that armed control was necessary to keep the work going and prevent desertion. ${ }^{139}$ In pSallier I, a scribe of the Head of Record-Keepers of the Royal Treasury reports to his superior on having correctly paid the seasonal labourers who were bringing in the harvest of the King's fields in bread (akk) on a daily basis and ointment three times a month. ${ }^{140}$

From the time of Ramesses IV, some precise workforce sizes are known: the rock inscription in the Wadi Hammamat dating to the king's first year lists 10 sculptors, 20

\footnotetext{
${ }^{136}$ pSallier IV vso. 9,1-4, Gardiner, LEM, 93f., Caminos, LEM, 355f.

137 pAnastasi I 16,5-17,2, Fischer-Elfert, Satirische Streitschrift. Textzusammenstellung, 117-119, and id., Satirische Streitschrift. Übersetzung, 143-147.

${ }^{138}$ Rock stela by Sethy I at Gebel es-Silsila, 11. 6-10, KRI I, 60:10-61:1, RITA Translations I, 52, and RITA Notes and Comments I, 56f., as well as Davies, Egyptian Historical Inscriptions, 203, see also below $\S ~ 4.4 .3$. Cf. also the stela Cairo CGC 34504 by Ramesses II from the area of Heliopolis, focussing on the king's role as the good shepherd of his workforce, KRI II, 361:2-362:12.

139 pTurin B vso. 2,3-11, Gardiner, LEM, 126f., Caminos, LEM, 469-471.

140 pSallier I 5,2-4, Gardiner, LEM, 81f.; Caminos, LEM, 307-312.
} 
stonemasons, 20 desert policemen, 50 stone carriers, 100 quarrymen, and 200 carriers; these were headed by middle-ranking paramilitary (desert police), administrative and temple personnel. ${ }^{141}$ Later, in regnal year 3, the executive staff of a much bigger expedition ${ }^{142}$ consisted of 2 Royal Butlers, 1 Lieutenant of the Army, 1 Overseer of the Treasury, 2 Tax Administrators, 1 Charioteer of the Royal Residence, 1 Register Scribe and 1 Allocation Scribe of the Army, 1 Head of the Army-Accountants(?) (Hrj-ATw.w n(.w) mSa) ${ }^{143}$ and 1 Overseer of Craftsmen. All of them were mentioned by name. They controlled, with the aid of 20 Scribes of the Army, 20 Stablemasters of the Royal Residence, 20 Army-Accountants, and 50 Charioteers of the Chariotry a workforce of 5'000 men, joined by 200 rowers from the fishermen's units of the Royal Residence, 800 Apiru as well as 2'000 workers from royal temples. In addition, a Deputy of the Head of the Desert Police commanding 50 policemen and familiar with the geography and geology of the region, watched over 130 quarrymen, their 3 overseers, and 6 artists. The list finally includes a Director of Priests and Overseer of Cattle as well as 50 priests, scribes and lower-ranking administrators. The assignment of executive personnel from different state departments such as the Royal Palace, the Treasury, the Cattle Ministry, the Royal Chariotry, Desert Police, the army, and temple administration shows that these branches worked together and that cooperation worked very well. This was of paramount importance when it came to concerted public projects. During the mission to the Wadi Hammamat, the mentioned 20 stablemasters attended and fed the horses of the deployed chariotry. Charioteers and Army District-Officers must have been in charge of protecting the expedition from assaults by desert people, but also of controlling the large workforce, preventing corvée workers and prisoners from running off. ${ }^{144}$ Provisions were commissioned by the Director of the Treasury, tax administrators and the Overseer of Cattle, while the Army Scribes calculated the amounts of rations to be distributed among the workmen, craftspeople

\footnotetext{
${ }^{141}$ Rock stela 1l. 4-6, G. Goyon, Nouvelles inscriptions rupestres du Wadi Hammamat (Paris: 1957), 24f., 103106 No. 89 (KRI VI, 1:9-15), see also T. Hikade, Das Expeditionswesen im ägyptischen Neuen Reich. Ein Beitrag zu Rohstoffversorgung und Außenhandel (Heidelberg: SAGA 21, 2001), 38-40, 199-201, Kat.Nr. 113. ${ }^{142}$ Rock stela 1l. 13-18, J. Couyat, P. Montet, Les inscriptions hiéroglyphiques et hiératiques du Ouadi Hammamat (Cairo: MIFAO 34: 1912), 34-39 No. 12, pl. 4 (KRI VI, 12-14); see also L.-A. Christophe, „La stèle de l'an III de Ramsès IV au Ouadi Hammamat (No. 12)“, BIFAO 48 (1948), 1-38; M. Valloggia, Recherche sur les „Messagers“ (wpwtyw) dans les sources égyptiennes profanes (Geneva, Paris: Hautes Études Orientales 6, 1976), No. 133, 172-174 No. 133, and Hikade, Exepditionswesen, 41-44, 205-209 Kat.Nr. 120.

${ }^{143}$ In his translation of pLouvre 3171 from the $18^{\text {th }}$ Dynasty A.H. Gardiner, ,Ramesside Texts Relating to the Taxation and Transport of Corn“, JEA 27 (1941), 57, renders the title given in 1. 2,6, as ,Quartermaster of the Army"; since deliveries of grain to the Granary at Memphis by ship are concerned and the mentioned military officer takes care of payments, a relation of his function with army provisions and logistics seems plausible; cf. the documentation of the title presented in Cheverau, Prosopographie, 229 No. 35.01-06. In Haremhab's speos at Gebel es-Silsila, the Regent and designated successor to the throne takes orders from the king to make the
} ATw $n$ mSa "know counting better than the Lord of Writings (i.e., Thot) and be apter than the Lord of Hermopolis (i.e., again Thot) <in?> his recording of booty (kfa) that every man made in his (i.e., the king's) name among the swordsmen (xpSy.w) of the naval regiments" involved in an expedition by Haremhab to Nubia: broad hall, west wall, depiction of the co-regent of Haremhab (Paramessu(?)) with text, A.-C. Thiem, Speos von Gebel es-Silsileh. Analyse der architektonischen und ikonographischen Konzeption im Rahmen des politischen und legitimatorischen Programmes der Nachamarnazeit (Wiesbaden: ÄAT 47.1, 2000), scene no. 90, 142, 145-149, 321, pl. 61, on the title in question see 145 (p); cf. C.R. Lepsius, Denkmaeler aus Aegypten und Aethiopien (Genève: 1972 [reprint]), 3rd part vol. V-VI, pl. 120 b. Since in both sources, the title-holder is connected with the fleet, he might be an army accountant of the navy.

${ }^{144}$ In a fictional letter, pBologna 1094 rto. 11,9-vso. 1,6, a high military administrator addresses a charioteer, under whose management an old soldier seems to have been made a cultivator, Gardiner, LEM, 11, and Caminos, $L E M$, 31-33. See also the model letter on pTurin A vso. 4,1-3 contrasting the power of high military officers with the poor freedom of action low and middle administrators had (above $\S 4.2$ ). pTurin B vso. 3,1-9 addresses among other issues the desertation by corvée workers, some of which were prisoners, Gardiner, $L E M$, 127, and Caminos, LEM, 470-472. 
and military. The project was conducted by two Royal Butlers and a Lieutenant of the Army, guaranteeing direct royal contact and control and a smooth access to supplies and professional handling of quarried blocks or other stone monuments on their way to Egypt.

A model letter from the late $19^{\text {th }}$ Dynasty presents a project management as consisting of a high palace official, again a Royal Butler, and army commissaries of stores, i.e., two Lieutenants of the Army. As the latter were obliged to report to the Royal Butler, having been entrusted with the transporting and erecting of three royal stelae, it is evident that the military officers were subordinated to the palace official. ${ }^{145}$ It can be inferred that royal projects could be directed by authorized royal agents recruited from the king's close entourage, even though another professional context than that of the palace was in demand.

The role of army scribes engaged in building projects is also discussed in pAnastasi I: a Royal Scribe of Recruits (sS nfr.w nj nb.tAwj) and Royal Scribe of Orders to the Army

(sS-nsw sHn.t $\mathrm{n} \mathrm{mSa}$ ) had to calculate rations for an army at work, ${ }^{146}$ the quantity of mud bricks to be used for building a construction ramp, ${ }^{147}$ the size of the work force employed to drag an obelisk, also assessing the latter's weight and size, ${ }^{148}$ or to erect a royal colossal statue. ${ }^{149}$

According to a Ramesside model letter, soldiers as well as corvée-workers of Westsemitic descent, the so-called Apiru, were drafted to drag stones for a temple pylon under the supervision of a Head of the Police. ${ }^{150}$ In the same text, a jdnw $n$ pA mSa is again responsible for the transport of a royal statue and its erection in the temple precinct of Ptah at Memphis. ${ }^{151}$ Construction enterprises, and thus, workforces, including companies of soldiers, were sometimes monitored by the local administration of the city or district where a project took place, as a letter from a Steward and Mayor of Thebes suggests. ${ }^{152}$ The Police Commander Amenemone mentioned in pLeiden 348 is also known from historical records of the time of Ramesses II: In a biographical inscription, he sums up his career, which he started as a King's Retainer (Smsw-nsw); later on, he became a Charioteer (kDn) and Commander of Troops of the Army (Hrj-pD.t n pA mSa), an executive rank that qualified him to operate as Head of the Police (according to pLeiden 348) and Overseer of all Works at the King's Mansion of Millions of Years at Thebes (Luxor statue) at the end of his professional lifetime. ${ }^{153}$

It is difficult to determine which military rank was considered suitable for supervising a construction project under which circumstances. Certainly individual aspects such as a close relationship to the king and personal achievements and qualities prompting royal favour were determining factors in the nomination of a Director of Constructions as in any kind of promotion that took place in the higher echelons of bureaucracy. This routine was deeply rooted in the Egyptian social network system fostering individual success and merits granted by the king as well as absolute loyalty and obedience to the crown. As mentioned above, the military organization strongly interacted with economic institutions, in particular the State

\footnotetext{
145 pAnastasi V 23,7-25,2, Gardiner, LEM, 69f.; Caminos, LEM, 265-269.

146 pAnastasi I 13,6-7, Fischer-Elfert, Satirische Streitschrift.. Textzusammenstellung, 107, and id., Satirische Streitschrift. Übersetzung, 119.

${ }^{147}$ pAnastasi I 13,8-14,8, Fischer-Elfert, Satirische Streitschrift. Textzusammenstellung, 107-112, and id., Satirische Streitschrift. Übersetzung, 121-132.

${ }^{148}$ pAnastasi I 14,8-16,5, Fischer-Elfert, Satirische Streitschrift. Textzusammenstellung, 112-117, and id., Satirische Streitschrift. Übersetzung, 133-142.

${ }^{149}$ See already above.

${ }^{150}$ pLeiden 348 vso. 6,5-8, Gardiner, LEM, 134, Caminos, LEM, 491, 493f.

151 pLeiden 348 vso. 7,6-8, 1, Gardiner, LEM, 134f., Caminos, LEM, 492, 495f.

152 pTurin B vso. 2,3-4,1, Gardiner, LEM, 126f., Caminos, LEM, 469-473.

${ }^{153}$ Statue Luxor J 141, ride sight, 11. 3-11 (KRI III, 274:16-275:6).
} 
Granaries, the Treasury, the Royal Estates, the King's House itself, but also with local city governments. It is not always clear which side exerted more authority on the other. Sources rather suggest that orders from different offices or departments cooperating with each other were at times inconsistent.

\section{§ 4.4. Military administration abroad}

Egyptian foreign policy had a strong impact on both administration and military organization. After a long war against the Kushite kingdom, the Southern Nile valley and desert areas became part of the Egyptian empire, whose interests were represented by a provincial government. Its claim for hegemony in Western Asia made her a global player in a complex political system of kingdoms, petty princedoms and city-states, the balance of which was kept on the basis of diplomatic liaisons, economic agreements, and military dominance. In contrast to the situation in Nubia, Egypt's role in the Levant was not pursued by imposing a tight bureaucratic apparatus upon vassal kinglets and cities, but rather by exploiting local structures, at the head of which were vassal rulers and governors, and a loose network of administrative, military and diplomatic institutions and facilities relying on exchange between the residence and the Egyptian bases and subsidiaries abroad. ${ }^{154}$

\section{§ 4.4.1. Nubian provincial administration and the military}

From the beginning of the New Kingdom on, the highest authority of the administration of Nubia was the Viceroy (of Kush), bearing the double title sA-nsw (n KS) jmj-rA xAs.wt rsj.wt, “King's Son (in/of Kush) and Director of Southern Foreign Countries". Already during the Second Intermediate Period, the executive title ZA-nsw was used as a marker of direct subordination to the king in the titulatures of commanders, Tsw.w, of fortresses and fortified towns in Nubia. ${ }^{155}$ With the establishment of the governor's position, the combination sA-nsw (n KS) jmj-rA xAs.wt rsj.wt became the official designation of the

\footnotetext{
${ }^{154}$ See, among the huge variety of publications on the topic, D.A. Warburton, Egypt and the Near East. Politics in the Bronze Age (Neuchâtel: Civilisations du Proch-Orient. Série IV.1, 2001); R. Morkot, "Egypt and Nubia", in: Empires. Perspectives from Archaeology and History, S.E. Alcock et al. eds. (Cambridge: 2001), 226-251; M. Liverani, International Relations in the Ancient Near East. 1660-1100 BC (Houndmills: 2001); J.K. Hoffmeier, "Aspects of Egyptian Foreign Policy in the $18^{\text {th }}$ Dynasty in Western Asia and Nubia", in: Egypt, Israel, and the Ancient Mediterranean World. Studies in Honor of Donald B. Redford, G.N. Knoppers and A. Hirsch, eds. (Leiden, Boston: PdÄ 20, 2004), 121-141; D.B. Redford, From Slave to Pharaoh. The Black Experience of Ancient Egypt (Baltimore and London: 2004), 38-57; Spalinger, War in Ancient Egypt, 46-69, or E.F. Morris, The Architecture of Imperialism. Military Bases and the Evolution of Foreign Policy in Egypt's New Kingdom (Leiden and Boston: PdÄ 22, 2005). Cf. now also M. Müller, “A View to a Kill: Egypt’s Grand Strategy in her Northern Empire", in: Egypt, Canaan and Israel: History, Imperialism, Ideology and Literature. Proceedings of a Conference at the University of Haifa, 3-7 May 2009, S. Bar, D. Kahn and JJ Shirley eds. (Leiden, Boston: Culture and History of the Ancient Near East 52, 2011), 236-251.

${ }^{155}$ One of the first Viceroys was Ahmose-Turi, who acted as a Commander of the fortress of Buhen under king Ahmose and was later on promoted into the function of the provincial governor combining the titles of zA-nsw and jmj-rA xAs.wt rsj.wt, see now in greater detail JJ Shirley, "Viceroys, Viziers \& the Amun Precinct: The Power of Heredity and Strategic Marriage in the Early $18^{\text {th }}$ Dynasty", JEgH 3.1 (2010), 75-82; on his inscriptions see D. Randall-Maciver and C.L. Woolley, Buhen. Text (Philadelphia: Eckley B. Coxe Junior Expedition to Nubia 7, 1911), 87-89, as well as L. Habachi, "The First Two Viceroys of Kush and their Family", Kush 7 (1959), 45-62; id., "Four Objects Belonging to Viceroys of Kush and Officials Associated with Them", Kush 9 (19619, 210-214, figs. 1-2, pl. XXVII, and Urk. IV, 79:5-81:8 (announcement of enthronement of Thutmose I published on three stelae from different locations, Wadi Halfa, Kuban, and the region of the First Cataract, cf. B. Bryan, "The Eighteenth Dynasty before the Amarna Period (c.1550-1352 BC)", in: The Oxford History of Ancient Egypt, I. Shaw ed. (Oxford, New York, 2000), 231). See also Spalinger, War in Ancient Egypt, 47f., 50, and Redford, From Slave to Pharaoh, 40f.
} 
Viceroys. The expanded version sA-nsw n KS, "King's Son of/in Kush", appears as the standard form of the rank from the middle of the $18^{\text {th }}$ Dynasty. ${ }^{156}$ Those who were selected for the position were, in general, senior military commanders who enjoyed the king's confidence. Ramesside Viceroys often included military ranks in their titulatures and emphasized their origins as officers of the specialized forces of the army, bearing titles such as Commander of Troops, Hrj-pD.t, Stablemaster, Hrj-jHw (nj nsw), Charioteer of the King, kDn tpj nj $\mathrm{Hm}=\mathrm{f}$ or even those of a Marshal, jmj-rA ssm.wt, and of His Majesty's LieutenantCommander of the Chariotry, jdnw nj $\mathrm{Hm}=\mathrm{f} n \mathrm{tj}$ n.t-Htrj, the highest positions in the royal chariotry. ${ }^{157}$ Although in the early New Kingdom Viceroys barely mention military ranks in their historical records, biographical sentences or epithets provide information on their respective careers as experienced combat soldiers in the royal entourage. Usersatet, governor of Nubia under Amenhotep II, was one of them. In rock inscriptions at the Southern border of Egypt he is called "the brave [of the King]" 158 or "the one concerned with booty, the brave in vile Kush", ${ }^{159}$ epithets that clearly refer to his military expertise. In very similar terms he is addressed by Amenhotep II as "the brave one who made booty in all the foreign countries, chariot warrior who fought for his Majesty [Amenhotep]" on a stela found at the fortress of Semna. ${ }^{160}$ Earlier in the $18^{\text {th }}$ Dynasty, during the reign of Hatshepsut and Thutmose III, the Viceroy Inebny-Amenemnekhu, in contrast, did not withhold his military ranks. In the same inscription that characterizes him as "the beloved of his Lord owing to his excellency, who followed his Lord on his steps in the southern and northern foreign country", he is qualified as Hrj-pD.t, Troop Commander, and Overseer of the King's Weapons, jmj-rA xa.w $\mathrm{n}(\mathrm{j}) \mathrm{nsw} .{ }^{161}$ At the dawn of the $18^{\text {th }}$ Dynasty, main operational areas for the Egyptian army were Upper and Lower Nubia, then under the control of the king of Kush, who resided in Kerma to the south of the third Nile cataract. This was also the sphere of action of the early Viceroys, some of whom report on successful attacks against the Nubian enemy. ${ }^{162}$ It can be

\footnotetext{
156 The first Viceroy to be known as a "King's Son of Kush" was Amenhotep under Thutmose IV, J. de Morgan et al., Catalogue des monuments et inscriptions de l'Égypte antique. Première série. Haute Égypte, vol. 1. De la frontière de Nubie à Kom Ombos (Vienna: 1894), 92 no 108, and now A. Gasse and V. Rondot, „The Egyptian Conquest and Administration of Nubia During the New Kingdom: The Testimony of the Sehel RockInscriptions“, Sudan \& Nubia 7 (2003), 44 with pl. 5. Ibid., 42 table 1 is a list of all known Viceroys of Nubia during the New Kingdom.

157 Gnirs, Militär und Gesellschaft, 135f.

158 de Morgan et al., Catalogue, 91 No. 100, and cf. Gasse and Rondot, Sudan \& Nubia 7 (2003), 43 No 3.

159 de Morgan et al., Catalogue, 91 No. 103, and cf. Gasse and Rondot, Sudan \& Nubia 7 (2003), 43 No 4. According to B. Bryan, The Reign of Thutmose IV (Baltimore: 1991, 89 n. 184, the inscription may have been Khaemwaset's, another important title-holder in the Nubian military administration.

${ }^{160}$ Stela Boston MFA 25.632, 1. 5, W. Helck, "Eine Stele des Vizekönigs «sr-Òt.t”, JNES 14 (1955), 22-31; Urk. IV, 1343:20-1344:1, for further translations see Wente, Letters, 27; G. Moers, “'Unter den Sohlen Pharaos'. Fremdheit und Alterität im pharaonischen Ägypten”, in: Abgrenzung - Eingrenzung. Komparatistische Studien zur Dialektik kultureller Identitätsbildung, F. Lauterbach, F. Paul and U.-C. Sander, eds. (Göttingen: 2004),133, and M. Müller, "Ägyptische Briefe aus der Zeit der 18. Dynastie", in: Texte aus der Umwelt des Alten Testaments. Neue Folge, vol. 3. Briefe (Gütersloh: 2006), 321-323. On Usersatet's military career see also JJ Shirley, "What's in a Title? Military and Civil Officials in the Egyptian $18^{\text {th }}$ Dynasty Military Sphere", in: Egypt, Canaan and Israel: History, Imperialism, Ideology and Literature. Proceedings of a Conference at the University of Haifa, 3-7 May 2009, S. Bar, D. Kahn and JJ Shirley eds. (Leiden, Boston: Culture and History of the Ancient Near East 52, 2011), 292 n.6.

${ }^{161}$ Block statue BM EA 1131, 1l. 9-12, Hieroglyphic Texts from Egyptian Stelae, \&c., in the British Museum, part V (London: 1914), 10 No. 374, pl. 34, and W.V. Davies, „Tombos and the Viceroy Inebny/Amenemnekhu“, Sudan \& Nubia 12 (2008), 28 and pls. 9-10.

${ }^{162}$ See e.g. the inscription left by the viceroy Turoy on Sehel island in year 3 of Thutmose I, Gasse and Rondot, Sudan \& Nubia 7 (2003), 41 pl. 3, or the inscription of year 20 of Thutmose III on the island of Tombos,
} 
followed that a SA-nsw in Nubia was originally a military function delegated by the king to qualified army commanders. After the conquest of Nubia and the establishment of a provincial government, the rank emphasized the administrative rather than the military aspect of the executive function. This semantic shift may explain why Viceroys of the early New Kingdom rarely refered to military ranks in contrast to their Ramesside fellow colleagues, whose military expertise was mandatory for the position of the provincial governor, but no longer inherent in the title of a SA-nsw n KS. ${ }^{163}$ Among later Viceroys, it was therefore quite common to add former army ranks to their administrative titles in order to prove their military specialization as commanders of elite troops and/or the chariotry.

Similar to the rank of the Commander-in-Chief of the Egyptian army, which was most often held by the designated crown prince, the Viceroy was the highest authority of the forces deployed in Nubia. Once Wawat (Lower Nubia) and Kush in the south were conquered and Kerma's political power smashed, the viceroy concentrated on the development of economic and administrative control of the new province. ${ }^{164}$ After the establishment of Egyptian control in Nubia, encroachments by the local population could occur, provoking military intervention on behalf of the provincial government. According to a stela erected by the Viceroy Merimose for Amenhotep III at Semna East, conscription for military interventions in Nubia heavily relied on local manpower: ${ }^{165}$

...Then an [arm]y of Pharaoh, L.P.H., was levied, which the Viceroy
headed,
consisting of ships' crews equipped with commanders, each man vis-
à-vis his village,
from the fortress town of Baki (Kuban) to the fortress town of †A-rA-
$\mathrm{y}$,
what makes navigating 52 jtr.w (about $546 \mathrm{~km}$ ).
...

The inscription suggests that the levy of an army in times of strife or upheaval was based on local conscripts. Relying on the transport of troops by ship, the levy could be accomplished at a rapid pace. Although the Viceroy decided upon military operations and strategies, these were often delegated to a deputy or a military officer of the governor. ${ }^{166}$ Necessity could, however, also lead a high civil title-holder like the Memphite Amenhotep Son of Heby to be appointed $a d$ hoc as commander of a Nubian campaign. Under certain

\footnotetext{
reporting on a punitive expedition by the king and on the Viceroy's effectiveness in delivering luxury Nubian goods, Davies, Nubia \& Sudan 12 (2008), 25-28, figs. 1-2, pls. 1-2, with further bibliography.

${ }^{163}$ Cf. C. Raedler, „Zur Prosopographie von altägyptischen Militärangehörigen“, in: Militärgeschichte des Pharaonischen Ägypten, 329-336, on the careers of two Viceroys under Ramesses II, Huy (see also below) and Setau.

${ }^{164}$ For the controversial discussion of the expansion of the province consisting of two regions see Morkot, in: Empires, 234-238, with further bibliography. On the administration of Nubia during the New Kingdom see I. Müller, Die Verwaltung der nubischen Provinz im Neuen Reich (Berlin: 1976).

${ }^{165}$ Stela BM EA138, 11. 2-5, Hieroglyphic Texts from Egyptian Stelae, etc. British Museum, part VIII, I.E.S. Edwards ed. (London: 1939), 21f. No. 657, pl. 20, Urk. IV, 1659:13-17, cf. T. Säve-Söderbergh, Ägypten und Nubien. Ein Beitrag zur Geschichte altägyptischer Aussenpolitik (Lund: 1941) 228, and Z. Topozada, „Les deux campagnes d'Amenhotep III en Nubie“, BIFAO 88 (1988), 154 and 164. Cf. also above the biography of Djehutimose (§ 4.3).

${ }^{166}$ In the $20^{\text {th }}$ Dynasty, for instance, Penniut, Deputy of Wawat, was mandated to handle local riots, G. Steindorff, Aniba, vol. 2 (Glückstadt, Hamburg, New York: 1937), pl. 102, and M. Fitzenreiter, "Identität als Bekenntnis und Anspruch - Notizen zum Grab des Pennut (Teil IV)", Der Antike Sudan. Mitteilungen der Sudanarchäologischen Gesellschaft zu Berlin E.V. 15 (2004), $178 \mathrm{f}$.
} 
circumstances, forces deployed in Nubia may have been, at least in parts, conscribed in Egypt. ${ }^{167}$

According to R. Morkot, the reorganization of the Egyptian administration of Nubia took place sometime during the reign of Amenhotep II or Thutmose IV, i.e., quite closely upon the territorial occupation. ${ }^{168}$ The office of the governor incorporated military personnel and scribes, while a Deputy of the Viceroy took over functions on the executive level. ${ }^{169}$ The military rank of a Commander of Troops of Kush, Hrj-pD.t n KS, a direct report of the Viceroy with close ties to the Residence (see below), was introduced during the late $18^{\text {th }}$ Dynasty. ${ }^{170}$ At that time, the sphere of viceroyal control reached from Hierakonpolis in Upper Egypt down to the $4^{\text {th }}$ cataract in Upper Nubia. ${ }^{171}$ An area of this size required a higher differentiation within the provincial government. The introduction of some new middleranking administrative positions seems to support this thesis. At that time, the Nubian province was divided into two zones, Lower (Wawat) and Upper Nubia (Kush), ${ }^{172}$

${ }^{167}$ Graffito at Biggeh, mentioning the King's Superintendant at Memphis Amenhotep Son of Heby in the function of a jmj-rA mSa nj nb-tA.wj, L. Habachi, „Aménophis III et Amenhotep, Fils de Hapou, à Athribis“, RdE 26, 30-33, pl. 2, and cf. Topozada, BIFAO 88 (1988), 156f. and 164.

${ }_{168}$ Morkot, in: Empires, 235f., and Redford, From Slave to Pharaoh, 41-43.

${ }^{169}$ For a general introduction see Säve-Söderbergh, Ägypten und Nubien, 175-195. See e.g. the inscriptions on the island of Sehel left by subordinates of the Viceroy Usersatet: a „Deputy of the King's Son“, jdnw nj zA-

nsw, a „Charioteer of the King’s Son“, kDn nj sA-nsw, and a „Scribe of the King's Son“, sS nj sA-nsw, L. Habachi, „The Graffiti and Work of the Viceroys of Kush in the Region of Aswan“, Kush 5 (1957), 13-36, and Gasse and Rondot, Nubia \& Sudan 7 (2003), 43f.; cf. de Morgan et al., Catalogue, 91 No. 106; 92 No. 112,100 No. 207.

${ }^{170}$ In the 18th Dynasty, the rank is held by two individuals: Intef(?)nakht and Khaemwaset. Intef(?)nakht left a rock inscription at Sehel, de Morgan et al., Catalogue, 102 No. 228bis; since the writing of the name is not absolutely clear, it cannot be excluded that the mentioned Troop-Commander of Kush is identical with another individual of the same rank, Onurisnakht (Jnj-Hr.t-nxt), from the reign of Ramesses II, Graffiti on Sehel, KRI III, 116:3, 5, 7, RITA Translations 80, and L. Habachi, "The owner of Tomb No. 282 in the Theban Necropolis", JEA 54 (1968), 109 figs. 2a-2c, and KRI III 250:4-5, RITA Translations 178, and Habachi, loc.cit., 110, fig. 3, pl. $17 \mathrm{a}$, in the latter text he is mentioned together with his colleague, the Stablemaster of the Residence Amenemope. According to I. Pomorska's analysis, Les flabellifères à la droite du roi en Égypte ancienne (Warsaw: 1987) 40f., the high palatine title of a "Fan-Bearer to the Right of the King" was held by Viceroys of Nubia from Thutmose IV onwards, whereas Troop Commanders of Kush did not make use of it before the $19^{\text {th }}$ Dynasty: ibid., 41 with references to sources Nos. 72, 82 (Onurisnakht), 98 and 117. The court title appears, however, already in the late $18^{\text {th }}$ Dynasty, i.e., in the titulary of a Troop Commander of Kush: Khaemwaset. A statue of his (Khartoum Museum No. 2690) was found in „Temple T“ at Kawa, M.F.L. Macadam, The Temples of Kawa. Vol. I. The Inscriptions (Oxford and London: 1949), Text, xii and 3f. Inscription No. II; Plates, pl. 4. It originally showed Khaemwaset together with his wife, whose name is lost, if she is not identical with the donor of the statue (mentioned in the main dorsal inscription), „Great One of the Harim of (king) Nebkheperure (Tutankhamun) Taemwadjsi“. This royal harim was located at „Sehetepnetjeru”, i.e., Faras, as we know from the fragments of a sandstone basin (Khartoum Museum No. 4449) that belonged to the same lady. The basin, in contrast, was found in the sanctuary of the so-called Hathor Rock at Faras, J. Karkowski, Faras V. The

Pharaonic Inscriptions from Faras (Warsaw: 1981), 89f. No. 8, pl. V. Taemwadjsi appears once more on a lintel from the same period, dedicated to the Viceroy of Nubia Hui, of whom she is said to be "his sister who makes his name live", fragment of a lintel from the temple of Tutankhamun at Faras, now Khartoum Museum No. 3745, Karkowski, Faras V, 130f. No. 74, pl. XV.

${ }^{171}$ According to two inscriptions in the Theban tomb of Huy, TT 40, broad hall, east wall, north side, N. de Garis Davies, The Tomb of Huy, Viceroy of Nubia in the Reign of Tut ankhamun (No. 40) (London: The Theban Tomb Series 4, 1926), 10-11, pl. VI, cf. D. Valbelle, "Formes et expressions de l'État Égyptien en Nubie au Nouvel Empire”, in: Actes de la VIII conférence internationale des études nubiennes Lille 11-17 Septembre 1994. Part 1. Communications principales (Lille: CRIPEL 17, 1995), 169.

${ }^{172}$ Wawat consisted of three key regions, Kush of up to six, see Spalinger, War in Ancient Egypt, 63. 
administratively reflected in the dual office of an jdnw nj «AwA.t, "Deputy of Wawat", and an jdnw nj KS, "Deputy of Kush". ${ }^{173}$

While in the time of Amenhotep II, the incorporation of locals into the imperial administration was not always positively approved by the King's House, ${ }^{174}$ later on, an Egyptianized Nubian elite became politically important and was integrated into the colonial networks. The key regions of the Nubian subprovinces, Wawat and Kush, were controlled by Nubian princes, wr.w n.w WAwA.t/Mjam and wr.w n.w KS. As revealed by their tombs and funerary equipments in Egyptian style, they maintained close relations with the Egyptian elite and the court. ${ }^{175}$ There must have indeed been a large number of acculturated natives who entered the Egyptian administration over time. After having become part of the Egyptian elite, they kept very often an Egyptian name and cannot be distinguished from native Egyptians by ethnical markers in the historical records. ${ }^{176}$ As an example, the Deputy of Wawat Penniut, who left his tomb at Aniba in the reign of Ramesses VI, was of Nubian origin. ${ }^{177}$

From the perspective of the residence, the most important aspect of the viceroyal administration was economical in nature: biographical inscriptions and tomb decorations refer to the exploitation of natural resources, especially the quarrying of gold in Lower Nubia, and the delivery of exotic goods and animals. ${ }^{178}$ The Treasury maintained close relations with the provincial administration, and it was its highest authority, the Director of the Treasury, who played an important role during the installation ceremonies of the Viceroy at the Residence, following from a scene in the tomb of Amenhotep/Huy, zA-nsw $n$ KS under Tutankhamun.

\footnotetext{
${ }^{173}$ Morkot, in: Empires, 235f. Cf. also representations of provincial administrators in the Theban tomb of the Viceroy Huy under Tutankhamun, TT 40, broad hall, east wall, south side, N. de Garis Davies, The Tomb of Huy, Viceroy of Nubia in the Reign of Tut ankhamun (No. 40) (London: The Theban Tomb Series 4, 1926), 16f., pls. XIII (upper register) and XXXIX.6.

${ }^{174}$ Stela Boston MFA 25.632, 11. 9-14 (Urk. IV, 1344:10-20), and see above n. 159. During the 2nd Intermediate Period and the early $18^{\text {th }}$ Dynasty Fortress Commanders in Nubia called themselves „officials, magistrates“, sr.w, see Redford, From Slaves to Pharaoh, 40 with further bibliography. The term used by Amenhotep II in his letter to Usersatet reproduced on the stela, may intentionally be chosen to allude to this specific socio-cultural context of the term and its political implications from the Egyptian prospective. For this section of the inscription and its interpretation see S. Morschauser, „Approbation or Disapproval? The Conclusion of the Letter of Amenophis II to User-Satet, Viceroy of Kush (Urk. IV, 1344.10-20)“, SAK 24 (1997), 203-222, who, however, reads wr, ,chief“, instead of sr, ibid., $210 f$.

${ }^{175}$ For iconographical evidence see a depiction of the children of Nubian princes in the tomb of Huy, TT 40, broad hall, west wall, south side, Ni. De Garis Davies, Tomb of Huy, pls. XXIII, XXVII-XXVIII, or the representation of a Nubian Royal Fanbearer, Mayherpery, with black flesh tones on his funerary papyrus, pCairo CGC 24095, Hauptwerke im Ägyptischen Museum, No. 142 fig. 142c. For decorated tombs of Nubian princes see E.S. Cohen, Egyptianization and the Acculturation Hypothesis: An Investigation of the Pan-Grave, Kerma and C-Group Material Cultures in Egypt and the Sudan during the Second Intermediate Period and Eighteenth Dynasty (Ann Arbor: 1993), 130-155, and in more general terms, T. Säve-Söderbergh, "The Cultural and Sociopolitical Structure of a Nubian Princedom in Tuthmoside Times", in: Egypt and Africa, 186-194; Valbelle, in: Actes de la VIII conférence, 1. Communications principales, 170, and Fitzenreiter, Der Antike Sudan 15 (2004), 180-183 with further bibliographical references.

${ }^{176} \mathrm{Cf}$. the theoretical approach to the problem by T. Schneider., „Akkulturation - Identität - Elitekultur. Eine Positionsbestimmung zur Frage der Existenz und des Status von Ausländern in der Elite des Neuen Reiches“, in: Der ägyptische Hof, 201-216, esp. 209, 211-212.

${ }^{177}$ Fitzenreiter, Der Antike Sudan 15 (2004), 169-193, and see again below.

${ }^{178}$ See e.g. the rock inscription by Amenemnekhu/Inebny of year 20 of Thutmose III at Tombos, 11. 6-8, above n. 161; the list of Nubian commodities in the shrine of Usersatjet at Qasr Ibrim (shrine No. 4, south wall), Urk. IV, 1345:1-15, and R.A. Caminos, The Shrines and Rock Inscriptions of Ibrim (London: ASE 32, 1968), 65-71, pls. 28-32, or the depiction of gold and foreign goods and animals in the tomb of Huy, TT 40, broad hall, east wall, south side, Ni. de Garis Davies, Tomb of Huy, 19, 21-28, pls. XVI-XVII, XXIII-XXX. Cf. the general approach by R.G. Morkot, „Nubia in the New Kingdom: The Limits of Egyptain Control“, in: Egypt and Africa, 294-301.
} 
Huy is depicted receiving the paraphernalia of his office, a wound-up sash or belt and the official golden seal of viceroyalty (xtm nj jAw.t sA-nsw). ${ }^{179}$ The tomb walls also show the collection of taxes and tribute and their transportation to Thebes, where they are turned over to the central institutions. ${ }^{180}$ Besides the two Deputies, further members of Huy's administrative staff-his personal scribe, a "Scribe of Gold Accounts", sS Hsb nbw, and a Commander of Rowmen, Hrj-Xny.t nj sA-nsw-were at his personal disposal. Also involved in the collection of gold were two Stablemasters, perhaps the two sons of Huy, who are mentioned with this rank in other inscriptions of the tomb. Under the authority of the Viceroy were also a Director of Cattle and Deputies respectively Governors, HA.tj.w-a.w, of Nubian towns and forts. ${ }^{181}$ This suggests that the forts had become more or less civic centers, endowed with temples, some of which were quite large. As the forts controled the flow of precious resources and products to Egypt or were located at important trade routes, a fortified enclosure wall guaranteed safe storage. ${ }^{182}$ Between the two Deputies of Nubia, the one controlling Wawat must have occupied the economically more important position, as most gold mining took place in the Eastern Desert. This seems to be confirmed by the titularies of the Deputies. While Deputies of Kush rarely mention additional functions, some of their counterparts in Wawat could be also distinguished as a Commander-in-Chief of the royal army in Nubia, ${ }^{183}$ a zS pr-HD, "Scribe of the Treasury" 184 being responsible for the accounting of gold in Nubia, ${ }^{185}$ or of a Governor of Aniba (Miam). ${ }^{186}$ A Deputy of Wawat maintained, like his superior, direct business relations with the Royal Treasury. This can be followed from a wall scene in the tomb of Penniut at Aniba, where the Viceroy honors his subordinate together with the Director of the Treasury. ${ }^{187}$ If the jdnw $n<A w A . t$ Hornakht from the time of Ramesses II known from a rock inscription at Abu Simbel ${ }^{188}$ is the same person as the jdnw $\mathrm{n}$ KS mentioned on door jambs at various Nubian sites ${ }^{189}$, we may conclude that either both offices could occasionally be held by one person or a Deputy of Kush could move up to the higher position of a Deputy of Wawat.

\footnotetext{
${ }^{179}$ Ni. de Garis Davies, Tomb of Huy, 10f., pls. V-VI.

${ }^{180}$ Valbelle, in: Actes de la VIII conférence, 1. Communications principales, 169.

${ }^{181}$ Ni. de Garis Davies, Tomb of Huy, 17-20, pls. XIII-XVIII. Cf. also J.K. Hoffmeier, “Aspects of Egyptian

Foreign Policy in the $18^{\text {th }}$ Dynasty in Western Asia and Nubia", in: Egypt, Israel and the Ancient Mediterranean World. Studies in Honor of Donald. B. Redford, G.N. Knoppers and A. Hirsch eds. (Leiden: Probleme der Ägyptologie 20, 2004), 126f.

182 Morris, Architecture of Imperialism, 810-812.

${ }^{183}$ Graffito of Mery at Abu Simbel from the time of Sethy II, KRI IV, 282:11, RITA Translations IV, 202: jrj.n

zS pr-HD jmj-rA mSa nj nb-tA.wj m †A-stj jdnw Mry n «AwA.t, ,made by the Scribe of the Treasury, the Army-Commander of the Lord of the Two Lands in Nubia, the Deputy of Wawat Mery“.

${ }^{184}$ Rock inscription of Hornakht at Abu Simbel from the time of Ramesses II, showing the title sequence: $z S$

sHnw n mSa zS pr-HD Hsb nbw n nb-tA.wj m †A-stj HA.tj-a n Mjat jdnw n «AwA.t, ,Scribe of Commands of the Army, Scribe of the Treasury, who reckons the gold for the Lord of the Two Lands in Nubia, Governor of Miam and Deputy of Wawat“, KRI III, 118:13-14, RITA Translations III, 81, and Mery's graffito in loco, see n. 182.

${ }^{185}$ See again the rock inscription left by Hornacht at Abu Simbel, n. 183.

${ }^{186}$ Again Hornacht, see n. 183.

187 G. Steindorff, Aniba, vol. 2 (Glückstadt, Hamburg, New York: 1937), pl. 102, cf. also Fitzenreiter, Der Antike Sudan 15 (2004), 178.

188 See n. 183.

${ }^{189}$ Door-jamb from Amara-West, now Khartum Museum 2-R-A/2, KRI III, 117:9, RITA Translations III, 80; and door-jamb from Abri, now Khartum Museum 14412, KRI III, 117:12, RITA Translations III, 80, and doorjamb from Sai, now Khartum Museum 446, KRI III, 117:14, RITA Translations III, 81, see also A. Fouquet, „,Deux hauts fonctionnaires du Nouvel Empire en Haute-Nubie“, CRIPEL 3 (1975), 133-136, Doc. 6-8, fig. 5.
} 
Troop Commanders of Kush were often distinguished as members of the royal court by the title of a Fan-Bearer to the Right of the King, TAj-xw Hr wnmj-nsw. ${ }^{190}$ An entry in pBibliothèque Nationale 211, a timber account referring to institutions and houses at Memphis from the time of Sethy I, suggests that they dwelled, at least partly, at the capital, since it mentions among others the "house of Khay, Troop-Commander of Kush". ${ }^{191}$ The Turin Judicial Papyrus, which gives insight into the legal proceedings against members of the court who had planned to commit regicide, bears indirect witness to this practice during the early $20^{\text {th }}$ Dynasty, as one of the convicted from the royal entourage was a Troop Commander of Kush. ${ }^{192}$ When Troop Commanders of Kush acted as official executives abroad, they were granted, like the Viceroys of Kush, the title of an Overseer of the Southern Countries, jmj-rA XAs.wt rsj.wt. ${ }^{193}$ This mandate oscillated between logistical, military and administrative tasks at the border or abroad, distinguishing members of the provincial government who were in charge of tax and tribute collection. The Golénischeff Onomasticon seems to confirm this, as it lists the hybrid form jmj-rA xAs.wt n.w FArw KS, "Overseer of Foreign Countries of the Levant and of Kush", ${ }^{194}$ after the title combination jdnw jmj-rA xtm.w n.w $p<A>$ ২AD-wr, "Deputy and Commander of the fortresses of the Sea", and those of tax retrieving personnel such as "Scribe of Assemblage", sS sHwj, "Overseer of Entrances to the Rearland", jmj-rA HA.w<t>y n.w pHw.w, or "Head of Taxes in the Entire Country", aA nj St $n$ tA <r>-Dr=f. ${ }^{195}$ Some Troop Commanders of Kush were also sent on specific missions as royal messengers, wp.wtj.w-nsw. ${ }^{196}$ The Abydos Decree of Sethi I at Nauri, a rock formation north of the Third Nile Cataract in Nubia, suggests that the imperial administration of Nubia intervened on its own terms in transactions and other kinds of

\footnotetext{
${ }^{190}$ Pomorska, Les flabellifères, 41 with references to sources Nos. 72, 82, 98 and 117.

${ }^{191}$ pBN 210 rto. Fragment B vso. 1. 4, KRI I, 272:12, and RITA Translations I, 225, and RITA Notes and Comments I, 181 (b), and see also above $\S 3.2$.

${ }^{192}$ For reasons of ostracism, the papyrus does not render the proper name of the Commander, but echoes it in a

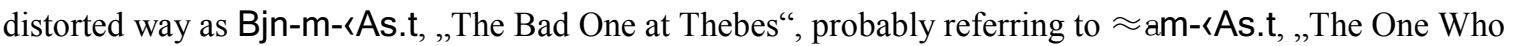
Appeared at Thebes“, Turin Judicial Papyrus 5,3, KRI V, 357:5-10, RITA Translations V, 300. For the pejorative renaming see G. Posener, „Les criminels débaptisés et les morts sans noms“, RdE 5 (1946), 51-56. Cf. aussi Vernus, Affaires, 153-156, et Y. Koenig, „À propos de la conspiration du harem“, BIFAO 101 (2001), 300f. „Binemwase“ got involved in the conspiracy at the instigation of his sister, a member of the royal harim. ${ }^{193}$ For instance, documented for Pyay, an associate of the famous Bay from the time of Siptah/Tausret, graffito in the hall of the temple of Ramesses II at Abu Simbel, KRI IV, 366:13-14, RITA Translations IV, 265, or for Nebmaatranakht from the reign of Ramesses VI, graffito at the temple of Amenhotep III at Kawa, KRI VI, 358:4-6, M.F.L. Macadam, The Temples of Kawa, vol. 1 (London: 1949), 84-86, pls. XXIV-XXVII. According to W.J. Murnane, „Overseer of the Northern Foreign Countries“": Reflections on the Upper Administration of Egypt's Empire in Western Asia“, in: Essays on Ancient Egypt in Honour of Herman te Velde, J. van Dijk ed. (Groningen: Egyptological Memoires 1, 1997), the title expresses a more generic military responsibility most often assigned to the Viceroy of Kush.

${ }^{194}$ Cf. the title jmj-rA xAs.wt n.w $\approx$ A rw, „Overseer of the Foreign Countries of the Levant“ born by the Chief of the Police and Royal Charioteer Penre under Ramesses II, funerary cone, KRI III, 270:9, RITA Translations III, 192, and N. de Garis Davies - M.F.L. MacAdam, A Corpus of Inscribed Egyptian Funerary Cones (Oxford: 1957), No. 524; E. Hirsch, "Die Beziehungen der ägyptischen Residenz im Neuen Reich zu den vorderasiatischen Vasallen. Die Vorsteher der nördlichen Fremdländer und ihre Stellung bei Hofe”, in: Der ägyptische Hof des Neuen Reiches. Seine Gesellschaft und Kultur im Spannungsfeld zwischen Innen- und Außenpolitik. Akten des Internationalen Kolloquiums vom 27.-29. Mai 2002 an der Johannes GutenbergUniversität Mainz, R. Gundlach and A. Klug, eds. (Wiesbaden: KSG 2, 2006), 141f. with fig. 11.

195 A.H. Gardiner, Ancient Egyptian Onomastica, vol. 1. Text (Oxford: 1947), 33*f.

${ }^{196}$ Nakhtmin, a Troop Commander of Kush under Ramesses II, is called „,Royal Messenger to Every Foreign Country“ in a graffito at Aswan, KRI III, 115:10, RITA Translations III, 79; Habachi, JEA 54 (1968), 112 fig. 4.
} 
economic procedures related to state institutions: Composed to the benefit of personnel and property of the King's Mansion of Millions of Years at Abydos, the firman was principally directed against representatives of the Nubian viceroyalty, among them no less than the Viceroy himself, any Troop Commander, and other high military personnel related to them such as Fortress Commanders, Charioteers, Stablemasters, Standard-Bearers, and lower ranks. ${ }^{197}$ Among the provincial cadres, an uncommon rank is mentioned: Head of Nubians (of the land of Kush), Hrj nHsy.w (n pA tA nj KS). ${ }^{198}$ As the term nHsy.w is written with the determinatives of people and of foreign land, the title does not refer to a military unit consisting of Nubian mercenaries, but to Nubian ethnicity and, therefore, designates Nubian princes actively involved in the imperial government (see above).

Sources show that the integration of Nubia as part of the Egyptian state during the New Kingdom was based on a continuous and tight administrative system with its own hierarchy and strong ties to the Palace. As the provincial government in Nubia was based on military control, the viceroyalty always maintained close relations to the army. At the same time, due to Egypt's economic interests in Nubia, it was administratively affiliated to royal departments such as the Offices of the Treasury, of the Granary, and of Cattle.

\section{§ 4.4.2. Foreign administration and the military in Asia}

Political and economic control of Egypt's northern sphere of influence worked in different ways, except for "the Way of Horus", the desert path leading from the fortress of Sile (ancient Tjaru) to Gaza (ancient Gadjati) in the Levant, as it was, in fact, Egyptian territory.

Maintenance and control of the strongholds (nxtw, m-k-d-r) ${ }^{199}$ and secured wells or water reservoirs along this way might have been comparable to that of the forts in Nubia, allowing state institutions equally fast access. As E.D. Oren pointed out, this administrative and military network along the Sinai corridor was already established during the reign of Thutmoses III, its sites equipped with defense systems, industrial and storage facilities serving as military, administrative, and economic centers and, thus, permanently providing safe and rapid movements of armies and messengers as well as smooth transport of goods. ${ }^{200}$ The excerpt of a border-journal preserved on pAnastasi III vso. from the reign of Merenptah suggests how transit on the Sinai corridor might have worked. ${ }^{201}$ The journal recorded passing messengers and military personnel on their way in and out of Egypt within a decade. The term Tsj $r \approx$ \&w, "climbing up, mounting to the Levant", 202 used in the text for travellers heading north-east, ${ }^{203}$ implies that the route to the Levant meant crossing hill country, whereas the action of returning to Egypt is classified as "coming (back) (to the place) where One is (i.e., the King in the Royal Residence)", jj r pA ntj tw.tw jm. In one instance, the verb spr, "reaching, arriving", is linked with the location pA xtmw ntj $\mathrm{m}^{\text {TM} A r w, ~ " t h e ~ f o r t r e s s ~ o f ~ S i l e " ~}$

\footnotetext{
${ }^{197}$ KRI I, 45:6-58:15; RITA Translations I, 38-50, and RITA Notes and Comments I, 48-55 with bibliography. ${ }^{198}$ L. 36 and 1.88 of the inscription.

${ }^{199}$ Morris, The Architecture of Imperialism, 820 and 817-820.

200 The military network of the Ways of Horus is, to a great extent, known from battle reliefs by Sethi I at Karnak and from the topographical list of pAnastasi I; archaeological evidence confirms the textual references, see E.D. Oren, „, The Establishment of Egyptian Imperial Administration on the "Ways of Horus": An Archaeological Perspective from North Sinai“, in: Timelines. Studies in Honour of Manfred Bietak, E. Czerny ed., vol. 2 (Leuven, Paris, Dudley, MA: OLA 149/2, 2006), 279-293, and cf. G. Cavillier, „The Ancient Military Road Between Egypt and Palestine Reconsidered: A Reassessment“, GM 185 (2001), 23-33.

${ }^{201}$ pAnastasi III vso. 6,1-5,9, Gardiner, $L E M, 31: 4-32: 7$ (for the sequence of the text lines see Gardiner's comment on p. 31); Caminos, LEM, 108-113.

${ }^{202}$ At the end of the last, incomplete entry, pAnastasi III vso. 5,8-9, which uses again Tsj, the text breaks off abruptly without rendering the purpose of transit and its destination.

${ }^{203}$ Cf. already Caminos, LEM, 109.
} 
(see also below). ${ }^{204}$ The entry applies to a group of Troop Commanders descending from royal wells in hill land towards the fortress of Sile in order to investigate in a matter of unknown concern. Although opinions diverge, it seems likely that the fortified bordertown of Sile was the place where the observations took place and where transit records were carried out and filed before important informations were sent to the Residence in Egypt. ${ }^{205}$ This hypothesis is confirmed by dispatches of this kind sent from the fortress of Semna, the southern-most stronghold of Egypt's Nubian territories during the late $12^{\text {th }}$ Dynasty. ${ }^{206}$ Although they date to the Middle Kingdom and relate the movements of mDAj.w in the desert, they show that meticulous recording of events, sometimes even including the time of the day, at and near fortresses was a constant procedure by the military administration of Ancient Egypt. ${ }^{207}$ The New Kingdom border journal from Sile lists all the border transits within the given period of ten days, recording the exact date, the persons involved by title and name, the destination of the border crossers and the purpose of their mission. Beside one case of perhaps legal investigation (smtr) at the fortress of Sile already mentioned above, ${ }^{208}$ the most frequent reason for crossing the Egyptian border were errands between the Royal Residence and foreign princely courts or Egyptian administrative centers and garrisons. Within a decade, six messengers passed border clearance, most of whom bore the title of an ordinary "retainer", Smsw + place name, supplemented by the name of the institution or foreign city where they came from. ${ }^{209}$ According to their names or those of their fathers, they were of foreign descent. As native speakers of West-Semitic language and well acquainted with the topography of Canaan, they were the perfect couriers in the imperial communication network. Also, an Egyptian military officer stationed at a Syro-Palestinian royal settlement appears as an envoy of dispatches sent to the Royal Court by a Garrison-Commander and a Deputy of the mentioned town, the two highest authorities of the place and, thus, his superiors. ${ }^{210}$ The last entry relates to a Chariotreer of the Great Stable of Merenptah at the Residence "going up <to the Levant>". While no further details are given regarding the offices at the Residence where the dispatches were delivered, both the recipients as well as the senders of dispatches and, in one case, even "tribute" or gifts, ${ }^{211}$ were listed accurately with title and name.

Sile, modern Tell Heboua, was located on a narrow strip of land that marked the Mediterranean coastline during the $2^{\text {nd }}$ millennium BC. In its surroundings, the ancient Pelusiac Nile arm opened into a large lagoon or the open sea, in the near of which supposedly another fortress, xtm pA <AD-wr, was located. ${ }^{212}$ During the New Kingdom, Sile consisted

\footnotetext{
${ }^{204}$ pAnastasi III vso. 6,4-5.

${ }^{205}$ This was already suggested by R.A. Caminos, „Grenztagebuch“, in: Lexikon der Ägyptologie vol. II, 898. Cf., however, Morris, Architecture of Imperialism, 480, who argues for a localization in one of the fortresses along the Way of Horus, since, otherwise, the fort of Sile would not be mentioned.

206 The fort is mentioned in the texts (pBM EA 10752 and 10771), Despatch No. I 11. 7, 12, and No. VI 1. 9, , P.C. Smither, „The Semnah Despatches“, JEA 31 (1945), 3-10.

${ }^{207}$ Intelligence information was collected and recorded at Semna and later communicated to an administrative headquarter at Thebes, see S. Quirke, The Administration of Egypt in the Late Middle Kingdom. The Hieratic Documents (New Malden: 1990), 191-193, and R.B. Parkinson, Voices from Ancient Egypt. An Anthology of Middle Kingdom Writings (Norman: 1991), 93. Small papyrus fragments of records similar to the dispatches from Semna were found at the fortress of Buhen, H.S. Smith, The Fortress of Buhen. The Inscriptions (London: Excavations at Buhen 2, 1976), 31, 34 Nos. 66 and 76, pls. LXIII and LXIIIA.

${ }^{208}$ pAnastasi III vso. 6,4-5.

${ }^{209}$ pAnastasi III vso. 6,$1 ; 6,6 ; 5,1$.

${ }^{210} \mathrm{Cf}$. however the translation by Caminos, LEM, 109, where he suggests that the letters were sent to the two mentioned title-holders and not by them.

${ }^{211}$ pAnastasi III vso. 6,9.

212 Oren, in: Timelines II, 281 with further bibliography. For the Fortress of The Great Green (Sea), see Morris, Architecture of Imperialism, 710, 804,
} 
of a fortified structure surrounded by satellite settlements and cemeteries. ${ }^{213}$ As early as the reign of Thutmoses III, the fort was enclosed by a massive defense system and included huge granaries and magazines as well as buildings of some size that might have served administrative purposes. ${ }^{214}$ The term used for the Fortress of Tjaru is always xtm, not mnnw.

According to E.F. Morris, xtm denotes border and sealing forts "installed at locations at which entrance to the Nile Valley could be effectively controlled and monitored", while mnnw applied to fortress-towns with a denser population, following the model of an Egyptian town (see above). They are known from Nubia, but also along the Mediterranean coast, where they formed a protective network against Libyans and Sea People. ${ }^{215}$ Egyptian forts are not known from Western Asia. There was no need for them, as representatives and troops of the imperial government were stationed at subdued or allied Levantine towns and cities, which had their own defense systems and administrative quarters. Only in regions without preexisting infrastructure royal settlements (dmj.wt) were founded. The border diary of pAnastasi III, which lists a Stable-Master of the Settlement of Merenptah situated "in the district of (the Prince?) Pa-Irem", an unidentified location in Syria-Palestine, from where letters were expediated to Egypt by local authorities, one of whom was a GarrisonCommander (see above), ${ }^{216}$ shows that these sites were, in fact, Egyptian garrisons.

Living and serving at the Fortress of Sile was considered especially hard, as we learn from the Decree of Haremhab (see also § 4.2), in which the king takes actions against the abuse of power and the unlawful confiscation of private property, as punishment inflicted on lower representatives of the administration or the army included physical mutilation, i.e., the cutting off of the nose, and banishment to Sile. ${ }^{217}$ It remains unclear whether delinquents were imprisoned and condemned to hard labour at Sile or sent there to serve in military service, as proposed by J.-M. Kruchten. ${ }^{218}$

Beyond the Way of Horus, Egyptian territories in Western Asia were not "owned" by the state, as Nubia was to a certain degree, for at least two reasons: The countryside was much less easily accessible. Also, from a political point of view, the Levant was fragmented into numerous kingdoms, principalities, and city-states with their own political rulership, densely populated areas, a high degree of social stratification and a well-functioning infrastructure. To try to impose on them a "colonial" model of political control similar to the vizeroyalty of Kush, was never a realistic option and would have been counterproductive. In fact, it was much more feasible to profit from preexisting political and social systems. After a long history of strife for domination, submission and alliances in this part of the Ancient Near East, the Egyptian administration relied heavily on a network of loyal vassal kinglets and citystates. Their princes and governors maintained close contacts to the Residence in Egypt,;219

\footnotetext{
${ }^{213}$ On the cemeteries of the $18^{\text {th }}-19^{\text {th }}$ Dynasties see J. Dorner, „Vorbericht über die Grabunskampagnen 1993-94 auf Tell Hebwa IV-Süd am Nordsinai, $\ddot{A} \& L 6$ (1996), 167-177; D.A. Aston, „Tell Hebwa IV - Preliminary Report on the Pottery“, $\ddot{A} \& L 6$ (1996), 179-197; and J. Dorner and D. Aston, „Pottery from Hebwa IV/South. Preliminary Report", CCÉ 5 (1997), 41-45.

${ }^{214}$ M. Abd el-Maksoud, Tell Heboua (1981)-1991). Enquête archéologique sur la Deuxième Période Intermédiaire et le Nouvel Empire à l'extrémité orientale du Delta (Paris: 1998), 36f., 45-48, 128f. figs. 1-2. On the epigraphic evidence from the site, the earliest of which dates to the beginning of the 12th Dynasty, see M. Abde el-Maksoud and D. Valbelle, „Tell Héboua-Tjarou. L'apport de l'épigraphie“, RdE 56 (2005), 1-44. ${ }^{215}$ Morris, Architecture of Imperialism, 804-814.

${ }^{216}$ pAnastasi III vso. 5,4-5,7. Cf. Morris, Architecture of Imperialism, 826.

${ }^{217}$ Ll. 13-23 (§§1-3), Urk. IV, 2143:15-2147:15, and Kruchten, Le Décret d'Horemheb, 28-79.

${ }^{218}$ Kruchten, Le Décret d'Horemheb, 79, refers to a tomb robbery papyrus, pBM 10053 vso. 2,18 (KRI VI, 758:7-8.), where a defendant declares in an oath that he may be sent to the ,garrison of Kush“, if he later withdrew his confession.

${ }^{219}$ Cf. W.J. Murnane, „Imperial Egypt and the Limits of Power“, in: Amarna Diplomacy. The Beginnings of International Relations, R. Cohen and R. Westbrook eds. (Baltimore and London: 2000), 101-111; C.R.
} 
some of them were even raised and educated at Pharaoh's Court or, in some cases, kept at the Residence as hostages. ${ }^{220}$ In this respect, the most important sources are the Amarna correspondence and the diplomatic exchange between the Hittite king and Ramesses II. ${ }^{221}$ The Amarna letters show that vassals, who had taken an oath of allegiance with Egypt, were expected to support their overlord's foreign policy vis-à-vis neighboring states and observe his economic interests. In exchange, when the King's House deemed it proper, Egyptian forces intervened in order to keep local conflicts low, but also to avert expansionistic efforts by other Great Powers of the Near East. ${ }^{222}$ In Akkadian, the vassals are called „mayors“, hazannu, while their dialogue partners appear as rabisu, ,commissioners“, or rabî, „Great Men", surrogates for a whole range of bureaucratic and military functions and ranks according to Egyptian terminology. ${ }^{223}$ In fact, a network of middle class military (jmj-rA jway.t, Hrj-pD.t, Hrj-jHw) and administrative (jdnw) personnel was established abroad, accompanied by subordinates and army units with residence at foreign political centers or Egyptian bases. ${ }^{224}$ A constant flow of couriers and messengers between Egypt, her bases abroad and foreign residencies was meant to guarantee good diplomatic relations with Egypt's allies and to keep vassals on a short leash. According to M. Liverani, the letters exchanged with vassal states followed a seasonal pattern referring to the preparations of goods to be sent to Egypt in spring and their proper transfer in late summer. ${ }^{225}$ Mutual political commitments, at times reenforced by diplomatic marriages, and the exchange of luxury goods were part of the international traffic as was the transport of trade goods, tribute or taxes, partly stored at

Higginbotham, Egyptianization and Elite Emulation in Ramesside Palestine. Governance and Acommodation on the Imperial Periphery (Leiden, Boston, Köln: Culture and History of the Ancient Near East 2, 2000), 136-142; R. Gundlach, C. Raedler and S. Roth, „Der ägyptische Hof im Kontakt mit seinen vorderasiatischen Nachbarn. Gesandte und Gesandtschaftswesen in der Zeit Ramses' II., in: Prozesse des Wandels in historischen Spannungsfeldern Nordostafrikas/Westasiens. Akten zum 2. Symposium des SFB 295 Mainz 15.10.-17.10.2001 (Würzburg: 2005), 39-67; S. Roth, „Internationale Diplomatie am Hof Ramses’ II.“, in: Der ägyptische Hof, $92-$ 97; Hoffmeier, in: Egypt, Israel, and the Ancient Mediterranean World, 126-128, and Murnane, in: Essays on Ancient Egypt, 252.

${ }^{220}$ J. P. Cowie, „Guaranteeing the Pax Aegyptiaca? Reassessing the Role of Elite Offspring as Wards and Hostages within the New Kingdom Egyptian Empire in the Levant", BACE 19 (2008), 17-28.

${ }^{221}$ Translations of the correspondences: The Amarna Letters, W.L. Moran ed. (Baltimore, London, 1992); Die ägyptisch-hethitische Korrespondenz aus Boghazköi in babylonischer und hethitischer Sprache, E. Edel ed. (Opladen: Abhandlungen der Rheinisch-westfälischen Akademie der Wissenschaften 77, 1994).

${ }^{222}$ W.J. Murnane, The Road to Kadesh. A Historical Interpretation of the Battle Reliefs of King Sety I at Karnak (Chicago: SAOC 42, $\left.{ }^{2} 1990\right), 1-38$; Murnane, in: Amarna Diplomacy, 101-111; A. James, „Egypt and Her Vassals: The Geopolitical Dimension“, in: Amarna Diplomacy, 112-124, and C. Zaccagnini, „The Interdependence of the Great Powers", in: Amarna Diplomacy, 143f. In this context, a historizing text on a cuneiform tablet found at Ugarit (RS 20.33, the so-called „lettre du général“) is of interest, as it relates to an impending attack of the Egyptian army-probably headed by the king himself-from the perspective of a proHittite Commander-in-Chief in Amurru, who writes this letter to his lord, S. Izre'el and I. Singer, The General's Letter from Ugarit. A Linguistic and Historical Reevaluation of RS 20.33 (Tel Aviv: Ugaritica V, 1990), 128144, proposing a date of the text in the 14th century BCE (Amarna Period), followed by S. Lackenbacher, Textes akkadiens d'Ugarit. Textes provenant des vingt-cinq premières campagnes (Paris: Littératures Anciennes du Proche-Orient, 2002), 54, 66-69. In contrast, M. Dietrich, „Der Brief des Kommandeurs Šumiyanu an den ugaritischen König Niqmepa (RS 20.33). Ein Bericht über Aktivitäten nach der Schlacht bei Qadeš, 1275

v.Chr.“, UF 33, 2001, 118-183, argues in favour of a later date, i.e., the reign of Ramesses II. He is supported by J. Freu, Histoire politique du royaume d'Ugarit (Paris: Collection KUBABA Série Antiquité XI, 2006), 80-86.

${ }^{223}$ See D.B. Redford, Egypt, Canaan, and Israel in Ancient Times (Princeton: 1992), 201.

${ }^{224}$ Again Redford, Egypt, 201-207.

${ }^{225}$ M. Liverani, „A Seasonal Pattern for the Amarna Letters“, in: Lingering over Words: Studies in Ancient Near Eastern Literature in Honor of William L. Moran, T. Abusch, J. Huehnergard, and P. Steinkeller eds. (Atlanta: HSS 37, 1990), 337-348. 
the Egyptian headquarters abroad, or the transfer of traitors and delinquents. ${ }^{226}$ Besides diplomatic and trade expeditions, army and chariotry units were sent out and stationed at Egyptian garrisons, hosted by foreign governors or princes or by the Egyptian authorities of a royal foundation abroad. Caravansaries provided accommodations and facilities for imperial officials and traders on their journeys to and from Egypt. ${ }^{227}$ The Akkadian texts confirm that the diplomatic corps was multifaceted, ranging from ordinary runners delivering tablets and letters to royal ambassadors (wp.wtj.w-nsw) sent out on missions of high political impact. The latter often qualified as officers of the Chariotry and Commanders of Bowmen Troops, ${ }^{228}$ but could also be high courtiers and officials, who had become involved in the correspondences between vassal states and the King's House, receiving and commissioning diplomatic letters in the place of the king. Such a person was Huy: He acted as a Royal Ambassador for Ramesses II and was in charge of negotiating the contract terms of a diplomatic marriage, the so-called First Hittite Marriage, between the Hittite and the Egyptian court and, after the pact was settled, of excorting the foreign princess safe and sound to the Egyptian border. ${ }^{229}$ It seems that the same Huy communicated with other foreign allies such as the city-state of Ugarit. One of Ugarit's governors, Takuhlina, whose earlier career had led him to Karkemish and, later on, to the Hittite Court at Hattusha, sent a letter to ,the Great One Haya", concerning a transaction of wheat. The cuneiform tablet was found at Aphek, where a fortified structure was identified as an Egyptian residency with an adjacing caravansary, ${ }^{230}$ implying that Haya/Huy must have temporarily resided at the mentioned Egyptian headquarter. According to Y. Goren et al., Aphek was annexed to the territory of Jaffa, which was under Egyptian control in the $13^{\text {th }}$ century BCE, and provided a command center, from where the international road could be supervised. Other texts found at the site suggest that the base also served as a control post for messengers and transportation of merchandise. ${ }^{231}$ After a long career in the army as a senior commander (Huy was Troop-Commander and Marshal, Lieutnant-Commander of the Chariotry and Troop-Commander of Sile) and as a successful diplomat interacting with northern kingdoms and city-states, he finally took over the highest rank of Egypt's imperial administration, that of Viceroy of Kush.

Life abroad could have different faces according to function and rank. In one of the texts assembled on pBologna 1094, a Royal Scribe and Majordomo from Memphis is asked to take care of an ordinary stablemaster, an employee of his, who had just returned from the Levant after a five years term of active service as a Chariot Shield-Bearer. ${ }^{232}$ To avoid the

\footnotetext{
${ }^{226}$ Murnane, in: Amarna Diplomacy, 104; N. Mekawi, „Die Boten der Amarna-Briefe. Terminologie, Qualifikationen und Aufgabe“, in: The Realm of the Pharaohs. Essays in Honor of Tohfa Handoussa, vol. 1, Z.A. Hawass, Kh.A. Daoud and S.Abd El-Fattah eds. (Cairo: ASAE Supplément 37, 2008), 339-345.

227 This institution was identified by M. Kochavi at Aphek, situated on the strategic highway of the Via Maris between Egypt and Hatti, M. Kochavi, „The History and Archaeology of Aphek-Antipatris“, BA 44.2 (1981), 7780, and cf. Morris, Architecture of Imperialism, 577f. with n. 654.

${ }^{228}$ Mekawi, in: The Realm of the Pharaohs, 333-342.

${ }^{229}$ Cf. Habachi, Kush 9 (1961), 216-225, figs. 4-5, pls. XXVIII-XXIX; Gnirs, Militär und Gesellschaft, 74-79, and Raedler, in: Militärgeschichte des Pharaonischen Ägypten, 329-333.

${ }^{230}$ D.I. Owen, „An Akkadian Letter from Ugarit at Tel Aphek“, Tel Aviv 8 (1981), 1-17; I. Singer, ,Takuhlinu and Haya: Two Governors in the Ugarit Letter from Tel Aphek“, Tel Aviv 10 (1983), 3-25, and cf. Morris, Architecture of Imperialism, 577. Cf., in contrast, Higginbotham, Egyptianization, 289f., who takes the structures at Aphek not as a governor's residence, but as administrative building. For the archaeological evidence of residential architecture at Aphek see above n. 226.

${ }^{231}$ Y. Goren et al., „Provenance Study and Re-Evaluation of the Cuneiform Documents from the Egyptian Residency at Tel Aphek“, Ä\&L 16 (2006), 161-171.

${ }^{232}$ In pAnastasi V 13,6-7, the author of a letter speaks about „turning“ his son, who was ,,travelling to the Levant, $\approx A$ rw over to the fortress, $x t m$ “, which might have been the fortress of Tjaru, ,until his companions return to Egypt after six years“, meaning that 5-6 years of deployment abroad was probably a common practice in Ramesside times, Gardiner, LEM, 63; Caminos, LEM, 242f. The verb pna r, to turn over to, to reverse to,
} 
stablemaster being drafted a second time for deployment abroad, it is proposed to send his younger brother instead. From the letter, it can also be gathered that men levied as grooms (ma-ry-rw-jA) ${ }^{233}$ and sent to foreign countries were branded. ${ }^{234}$ The procedure may imply that desertion abroad was not uncommon. ${ }^{235}$

Many inscriptions provide evidence for the assignment of high officials and, in particular, officers, mostly of the chariotry, as royal ambassadors to Western Asia ${ }^{236}$ or bear witness to residencies or administrative headquarters occupied by Egyptian title-holders. From the time of Ramesses III, a Stablemaster of the Residence and Troop Commander(?), Djehutimose, left a model pen case at Megiddo, where he might have been accomodated as a Royal Envoy. ${ }^{237}$ He is perhaps identical with the Royal Fan-Bearer, Troop-Commander and Director of Foreign Countries Djehutimose, father of the Army-Commander and Superintendant Ramesses-user-khepesh, who must have resided at Beth Shan according to a decorated limestone door frame commissioned in his name. The frame was part of an impressive building erected in the neighborhood of the local temple, bearing similarities to Egyptian residential architecture. ${ }^{238}$ Beth Shan was not the only Asian city that served as an Egyptian headquarter secured by a military presence. Archaeological and textual evidence shows that also Deir el-Balah, Tell el-Ajjul, Gaza, Ashdod, Tel Mor and Jaffa along the Mediterranean coast had their own Egyptian bases in the late $18^{\text {th }}$ and $19^{\text {th }}$ Dynasties as well as Tell elFar'ah, Tel Sera', Gezer or Aphek in the Syro-Palestinian backland. ${ }^{239}$ Among the coastal sites, some could be considered twin towns: while one site was located at the Via Maris proper serving as a gate to land routes, its counterpart provided a harbor with access to the open sea. ${ }^{240}$ D.I. Owen speaks of a chain of Egyptian strongholds that ran along the Via Maris from Gaza to Beth Shan. ${ }^{241}$

may imply that the writer's son had intended to go to the Levant along with his companions, but that his father had spoiled this plan by letting him being stationed at the frontier fortress.

233 On this semitic loan-word see Hoch, Semitic Words, 132-134 No. 173.

${ }^{234}$ pBologna 9,1-9,6 (Gardiner, LEM, 8:9-9:1, and Caminos, LEM, 24-26), cf. also Gnirs and Loprieno, in: Ägyptische Militärgeschichte, 282.

${ }^{235} \mathrm{Cf}$. the negative picture of a soldier's life elaborated in the so-called Satire of Trades, S. Jäger, Altägyptische Berufstypologien (Göttingen: LingAeg Studia monographica 4, 2004), 258-293, and Gnirs and Loprieno, in: Militärische Kriegsgeschichte, 289-298.

${ }^{236}$ Cf. M. Valloggia, Recherche sur les ,,messagers“ (wpwtyw) dans les sources égyptiennes profanes (Geneva/Paris: Centre de Recherches d'Histoire et de Philologie de la IVe Section de l'École Pratique des Hautes Études II. Hautes Études Orientales 6, 1976), 239-271, esp. 265-268; H. El-Saady, „The External Royal Envoys of the Ramessides: A Study on the Egyptian Diplomats“, MDAIK 55 (1999), 411-425, and Gundlach, Raedler and Roth, in: Prozesse des Wandels, 39-67.

237 The rank of Troop-Commander is not completely preserved on the pen case. Like the military titles, wp.wtjnsw is part of the inscription, G. Loud, The Megiddo Ivories (Chicago: OIP 52, 1939), 11f., No. 377, pl. 62, and W.A. Ward, „The Egyptian Inscriptions of Level VI“, in: F.W. James, The Iron Age at Beth Shan. A Study of Levels VI-IV (Phaladelphia: 1966), 175.

${ }^{238}$ A. Mazar, „The Egyptian Garrison Town at Beth-Shean“, in: Egypt, Canaan and Israel, 167-168, 171-172; cf. Morris, Architecture of Imperialism, 755-758; Ward, in: The Iron Age at Beth Shan, 172-176, and Higginbotham, Egyptianization, 64f. According to Higginbotham, op.cit., 132-142, Egyptianizing architecture could, but must not per se be interpreted as truly Egyptian in origin, as Egyptian life-style was generally emulated by the Syro-Palestinian elites during the Late Bronze Age.

${ }^{239}$ E. Oren, ,'Governor's Residencies' in Canaan under the New Kingdom: A Case Study of Egyptian Administration“, JSSEA 14 (1984), 37-56, and again Morris, Architecture of Imperialism, fig. 29 on p. 397 and 514-583. Higginbotham, Egyptianization, 263-290, does not use the term governor's residence at all, but distinguishes different types of „Egyptian-style architecture“: center hall houses, three room houses, and administrative buildings (beside temples on pp. 290-301).

${ }^{240}$ Morris, Architecture of Imperialism, 577f., referring to Aphek and Jaffa on the one hand, and Ashdod and Tel Mor on the other.

${ }^{241}$ Owen, Tel Aviv 8 (1981), 12. 
How during military expansionism, foreign city-states were changed into Egyptian headquarters, may be gathered from the biography of Intef, a First Royal Herald under Thutmose III. According to his war records, Intef was in charge of the appropriation of rulers' residencies and their adaptation to Egyptian living and purification standards: ${ }^{242}$
Each palace (aH) on the back of a foreign country was
ins[pected](jp.w) [...]. ${ }^{243}$ I travelled at the head of the army, as the first of the troops. My Lord came to me in peace. I prepared them (i.e., the palaces for the arrival of the king) and provided them with everything desirable from the foreign land, making $<$ them $>$ more beautiful than the palaces of Egypt $(\mathrm{aH}<. \mathrm{w}>$ n.w Km.t) by purifying (swab), [clea]ning (twrj) and rendering impenetrable (sStAw) and holy (sDsr) their quarters (Hw.wt=sn) and each room (a.t) according to its purpose ( $\mathrm{r}$ jrj.w=s). I made the heart of the King happy about [everything], that was done [... ......], calculating the tribute (jn.w) of the rulers from every foreign country (consisting) of silver, gold, olive oil, incense, and wine.

Intef was entrusted with the preparation of adequate living conditions for the king as long as he resided in conquered land. ${ }^{244}$ It is probable that these palaces later on served as centers of the imperial administration. If they were, however, truly Egyptian property is another question. Amarna letter EA 292 (11. 29-38), e.g. confirms the presence of an Egyptian administrator and his troops in the city of Gezer, but, at the same time, stresses that the residency was, in fact, property of the local ruler and that only due to the latter's goodwill the Egyptians were comfortably accommodated there. ${ }^{245}$

Those who served or had served the imperial administration abroad on a more permanent basis and as executives with direct access to economic and military ressources of the vassal states were often distinguished as „Director of (Northern) Foreign Countries“, jmj-rA xAs.wt (mHt.wt). Sources do not support the idea that holders of this title acted as governors or heads presiding and controlling Asian territory ${ }^{246}$ similar to the position of a Viceroy of Kush in Nubia, whose rank was often linked to the title jmj-rA xAs.wt rsj.wt. ${ }^{247}$ As was already discussed further up, the title of a "Director of Foreign Countries" seems to apply, in general, to executive members of the imperial administration on missions abroad, aiming at strategic and/or economic benefits for the state. Following D.B. Redford's approach on Egypt's

\footnotetext{
${ }^{242}$ Stela Louvre C 26 from TT 155, 1l. 25-27, Urk. IV, 975:2-11, and cf. the translation by Redford, The Wars in Syria, 180f.; cf. E. Martin Pardey, "Der sog. Sprecher des Königs in der 1. Hälfte der 18. Dynastie", in: Essays in Honour of Prof. Dr. Jadwiga Lipinska (Warsaw: Egyptological Studies I 1997), 377-397, esp. 387-389. On his professional biography see also Shirley, in: Egypt, Canaan and Israel, 300-302.

${ }^{243}$ Redford, The Wars in Syria, 180f., translates ,was assessed for [supplies]“.

${ }^{244}$ Cf. Gnirs, in: Egyptian Royal Residences, 34f.

${ }^{245}$ The Amarna Letters, 335f., and Morris, Architecture of Imperialism, 563.

${ }^{246}$ Some scholars speak for up to four Egyptian provinces in the Levant, cf. Murnane, in: Essays on Ancient Egypt, 257. See, in contrast, the thoroughful analysis of Egyptian foreign policy in the Levant by Redford, Egypt, 199-203.

${ }^{247}$ Cf. e.g. O'Connor, in: Ancient Egypt, 208f. with fig. 3.4, or S. Israelit-Groll, „The Egyptian Administrative System in Syria and Palestine in the $18^{\text {th }}$ Dynasty“, in: Fontes atque pontes. Eine Festgabe für Hellmut Brunner, M. Görg ed. (Wiesbaden: ÄAT 5, 1983), 234-242, or Hirsch, in: Der ägyptische Hof, 136-139, who tries to identify a possible Director of the Northern Foreign Countries in the Amarna letters, and generally 151-155.
} 
imperial administration in the Levant, C.R. Higginbotham calls them, as well as the Royal Messengers, "circuit officials", whose permanent residence was in Egypt, not abroad. ${ }^{248}$ In Western Asia as in Nubia, these were often Troop Commanders, but they also ranked as Garrison Commanders (jmj-rA jway.t), Commanders of a Fortress (jmj-rA xtmw), Royal Stablemasters (Hrj-jHw), or Heads of the Desert Police (wr nj mDAj.w). ${ }^{249}$ Thus, Directors of the Northern Foreign Countries represented the middle level and not the highest echelons of the military organization, almost exactly corresponding to military ranks characterizing the commanders of Egyptian bases and garrisons in Syria and Palestine. ${ }^{250}$ Some biographical sources from the $18^{\text {th }}$ Dynasty shed light on the scope of a jmj-rA XAs.wt mHt.wt.

In the case of Djehuti, Garrison Commander under Thutmose III, the function was linked to administrative rather than military tasks. This can be inferred from the combination of the title with (Royal) Scribe, zS (-nsw), which occurs quite frequently in his sequences. ${ }^{251}$ Further information is provided by an inscription on a scribal statue of Djehuti from Byblos: 252

\begin{abstract}
Assessing the bAk.w-taxes and accepting the jn.w-deliveries, which, owing to the power of His Majesty, were brought as annual payment by the Princes [of] Retjenu. Shipping (them) southwards to Egypt b[y] the Director of the Entryway to the Northern Country, the Royal Scribe Djehuti, justified.
\end{abstract}

According to this biographical note, a Director of Foreign Countries in Western Asia was largely engaged in collecting tribute and all kinds of deliveries and transferring them to the Egyptian court. In this context Djehuti calls himself a "Director of the Entryway to the Northern Country", jmj-rA aA n xAs.t mHt.t, an exclusive title that presents him as having authority over all which went in and out of Western Asia, a function that must have been linked to a specific locality at the border of Egypt (Sile?) or, more likely, at the border of Egyptian territory in Western Asia (Gaza?). E. Hirsch proposes to identify this place with Byblos, where his statue was found. ${ }^{253}$

\footnotetext{
248 Redford, Egypt, 201f., Higginbotham, Egyptianization, 136f.

${ }^{249}$ See the compilation of title-holders by Hirsch, in: Der ägyptische Hof, 123-150 (chapter 2), and cf. Murnane, in: Essays on Ancient Egypt, 253f.

${ }^{250}$ Cf. again Murnane, in: Essays on Ancient Egypt, loc.cit. The famous Director of Northern Foreign Countries Djehuti from the reign of Thutmose III, who might have been identical with the besieger and conqueror of the city of Joppa according to a Ramesside narrative on pHarris 500 (A.H. Gardiner, Late-Egyptian Stories (Brussels: BAeg 1, 1932), 82-85; H. Goedicke, „The Capture of Joppa“, CdE 43 (1968), 219-233, and F. Junge, „Die Eroberung von Joppe“, in: Texte aus der Umwelt des Alten Testaments. Ergänzungslieferung (Güthersloh: 2001), 143-146), is distinguished as jmj-rA mSa on his gold bowl, now Paris Louvre N. 713 (Hirsch, in: Der ägyptische Hof, 156 No. 1 (with bibliography), which, however, might have been a modern forgery according to C. Lilyquist, „The Gold Bowl Naming General Djehuty: A Study of Objects and Early Egyptology“,

Metropolitan Museum Journal 23 (1988), 22-40. Once, Djehuti is mentioned as a Head of the Army, Tsw-pD.t, indicating a leadership role in a military operation, onguent vessel Leiden Rijksmuseum van Oudheden $\mathrm{H}$ 229/AAL 37 (again Hirsch, op.cit., 157 No. 6 (with bibliography).

${ }^{251}$ For the sources in question see Hirsch, in: Der ägyptische Hof, 126.

${ }^{252}$ Hirsch, in: Der ägyptische Hof, 124f., figs. 1-3, and 156 No. 3 (with further bibliography).

${ }^{253}$ Hirsch, in: Der ägyptische Hof, 125.
} 
Another title holder from the time of Thutmose III, Minmose, appears in his biography as an experienced officer and tax collector, responsible for the revenues of the Egyptian Treasury from West-Asian subdued cities and regions: ${ }^{254}$

I followed the Good God, the King of Upper- and Lower-Egypt (Menkheperre), bestowed with life, transversing every country that he crossed .........

[I crossed] Upper [Retjenu], following my Lord, imposing taxes on [Upper] Retjenu [in silver], [...], all kind of semi-precious stones, chariot $<s>$ and horses without number (as well as) uncountable cattle and flocks. I instructed the Princes of Retjenu (to pay) their annual bAk.w-payments, I imposed on the Princes of Nubia a tax of electrum ...?, gold, ivory, ebony (as well as) numerous ships (made of) palm-trees as annual payment like the servants of his palace. His Majesty has committed it to my care. Concerning these foreign countries, which I have mentioned, My Lord conquered them by virtue of his strength, his bow, his arrow, and his battle axe. I knew them, I taxed them, when they were assigned to the Treasury. I saw how the steadfastness of His Majesty's arm performed in combat, capturing 30 sites within Takhsi. Carried away were their princes, people and cattle, when I led the brave army of the king, being a Royal Cup-Bearer, ${ }^{255}$ who accomplished what was said.

This biography, like many others of the early $18^{\text {th }}$ Dynasty, does not bother with exact military ranking titles of the tomb owner and detailed accounts of his personal battle experiences. While the king was the only celebrated agent in the war report, the owner's fame was based on his individual relationship with the king as well as on his performances as tax collector and, above all, architect and Director of Works. In his records, the titles of Troop or Army Commander and Director of Northern Foreign Countries are missing, ${ }^{256}$ although there can be no doubt that he had occupied these positions.

Iconographic evidence is provided by the tomb of Amenmose at Thebes, who bore, beside the title jmj-rA xAs.wt mHt.wt, the military ranks of a Troop Commander and Stablemaster. While one scene shows the tomb owner in front of the king, presenting to him tribute and gifts delivered by Syro-Palestinian delegations, an adjacing wall depicts a scene of quite unconventional content: Amenmose escorted by an army division and administrative personnel on a trip abroad receives the goods a Levantine prince offers him in front of the city walls, such as precious metal work, raw material, cloth, cattle as well as wine or unguent. ${ }^{257}$ The depiction of armed troops suggests that transportation of tribute and/or diplomatic gifts from Western Asia to Egypt required protection, but also that at times, military pressure proved necessary when it came to collect foreign payments. This again explains why most

\footnotetext{
${ }^{254}$ Statue from Medamud, 11. 4, 7-17, Urk. 1441:15, 1442:3-20, see on his career H. Kees, Das Priestertum im ägyptischen Staat vom Neuen Reich bis zur Spätzeit (Leiden, Köln: PdÄ 1, 1953), 33-35, and de Meulenaere, MDAIK 37 (1981), 315-319.

255 Shirley, in: Egypt, Canaan and Israel, 310 with n. 91, reads jdnw instead of wdpw.

256 This corresponds with the missing title of a royal tutor, a function he must have temporarily held according to a cuboid statue showing the heads of two princes protruding from the cubus of the sculpture, see above n. 21 . According to Shirley, in: Egypt, Canaan and Israel, 308-311, however, Minmose's activities abroad were entirely administrative in nature.

${ }^{257}$ TT 42, tribute scene on the west part of the north wall, west side, N. de Garis Davies, The Tombs of Menkheperrasonb, Amenmose, and Another (Nos. 86, 112, 42, 226) (London: TTS 5, 1933), 27-30, pls. XXXIIIXXXV; west wall: collecting payments and gifts abroad, Davies, Tombs of Menkheperrasonb, 30f., pl.XXXVI; see again Hirsch, in: Der ägyptische Hof, 128f.
} 
Directors of the Northern Foreign Countries were Troop or Garrison Commanders, skilled in military logistics and acquainted with foreign territories and their local elite. Under Amenhotep II, Qenamun, owner of Theban Tomb No. 93, was Director of all the Northern Foreign Countries, Fortress-Commander, Standard-Bearer, and Royal Stablemaster, before he was promoted into the position of the Superintendant of the King's Estate at Perunefer (see above $\S 3.2$ ). Although his tomb inscriptions and scenes provide abundant information on his life as a high court official, little would be known of his military career, had he not left shabti depots at two different sites outside of Thebes, one at Zawiet Abu Mesallam near Giza, the other at Abydos. On a shabti from Zawiet Abu Mesallam he is called „Director of all the Northern Foreign Countries and Fortress-Commander"،, ${ }^{258}$ whereas the biographical inscription on a model coffin from Abydos referring to Qenamun's military career elaborates on various aspects of his activities as jmj-rA xAs.wt mHt.wt: ${ }^{259}$

$\ldots$

He (i.e., the king) made me Standard-Bearer (TAj-sry.t) of his great ones, and I was appointed to (the position of) a leader (HA.wtj).

I was the speaker of the men of his army (mdw.j sj.w/rmT $\mathrm{n}$

mnfy.t=f) in everything that was said. ${ }^{260}$

He made many kftj.w-ships ${ }^{261}$ thanks to me, ${ }^{262}$ equipped with golden

fans at the stern, when I followed His Majesty as companion of the

king, being his attendant.

He made many chariots thanks to me, worked in gold with (inlays of)

lapis lazuli, when I was in his following in Retjenu.

I became elevated and advanced, when I reached the Princes of the

Levant, all (of them) carrying their tribute.

Like Djehuty or Amenmose, Qenamun visited Syria in order to collect payments from the local rulers once they had pledged allegiance to the Egyptian crown. This activity was probably connected with his function as a Director of Foreign Countries. In his Theban tomb, built at the time when he was already appointed Superintendant of the King's Estate, his former military career is referred to only vaguely, i.e. by noting that he served the king as a

\footnotetext{
${ }^{258}$ H. Wild, „Contributions à l'iconographie et à la titulature de Qen-amon“, BIFAO 56 (1957),222-233, fig. 2 (C12), and cf. Hirsch, in: Der ägyptische Hof, 131f. with fig. 6.

${ }^{259}$ Rectangular model coffin from Umm el-Qaab, near the tomb of Den, excavation No. K 1042, inner sides 11. 715, F. Pumpenmeier, Eine Gunstgabe von seiten des Königs. Ein extrasepulkrales Schabtidepot Qen-Amuns in Abydos (Heidelberg: SAGA 19, 1998), 5-27, figs. 3-6, pls. 3-4, here: fig. 6 and pl. 4 center, left. The rank of a Royal Stable-Master is inscribed on the inner side of one of the short panels, Pumpenmeier, op.cit., fig. 61.28 (which is, in fact, line 27 of the inscription), and pl. 4 center right. The final part of the biography will be discussed below in $\S 4.5$.

${ }^{260}$ Pumpenmeier, Schabtidepot, 17 and 21 (k), reads jnk mdw.j n mnfy.t=f m Dd.t nb(.t), ,ich bin die

Autorität seines Heeres in allem, das gesagt wird“. For mdw.j see the term mdw.tj, „Redner, Demagog“, with a negative connotation in the Teaching for King Merikare, pPetersburg 1116 A vso., 1. 23, cf $W b$ II, 182: 6, and J.F. Quack, Studien zur Lehre für Merikare (Wiesbaden: GOF IV.23, 1992), 20-21, 166.

${ }^{261}$ For this Syrian type of seagoing ships see Pumpenmeier, Schabtidepot, 89-93.

${ }^{262}$ Pumpenmeier, Schabtidepot, 17 and 24, translates the two jrj.n=f $n=j$ phrases „He made for me“, which, however, implies that the king provided Qenamun with items that in other historigraphical contexts are exclusive royal goods. For the gold of honor and specific military decoration granted by the king to trustful soldiers see K. Butterweck-AbdelRahim, Untersuchungen zur Ehrung verdienter Beamter (Aachen: AegMon 3, 2002), 66-69, and her catalogue on New Kingdom documentation of this practice, ibid., 70-203.
} 
retainer and campaign companion. ${ }^{263}$ Again, on his tomb stela, which presents a résumé of his professional achievements, Qenamun's military past is summarized in two phrases: "Retainer of the King on his departures to the foreign land of the wretched Retjenu, who hovered over (tS) the Lord of the Two Lands on the battlefield in the hour of fighting off millions". ${ }^{264}$

\section{§ 4.4.3 Supplies of troops, fortresses and garrisons abroad}

In pAnastasi V, a model letter sent by a scribe to his father, the Troop Commander Bakenptah speaks of a delivery of kyllestis-bread and herbs to the officer and his servants. If this Bakenptah is identical with one of the two addressees in the preceding letter on the same papyrus, bearing the same title and name, it would be reasonable to assume that Bakenptah, along with another Troop Commander, was based at the stronghold (migdol) of SethyMerenptah-Beloved-of-Seth, which, according to the text, must have been located in the desert adjacing the Egyptian border in the east. ${ }^{265}$ E.F. Morris even proposes to identify the same fortification with the migdol depicted in the war reliefs of Sethy I, bearing this king's name ${ }^{266}$ which would be part of the chain of fortresses along the Way of Horus. At any rate, it seems that Bakenptah's location was secluded from civilization and that his living conditions did not offer a balanced diet. This would explain the sorrowful tone of his son's enquiry. From the 50 loaves he had intended to send together with the herbs, his deliveryman took only 30 loaves, leaving the rest behind, as the entire load would have been too heavy. Instead, 2 bricks of ointment were also part of the package. ${ }^{267}$ The fact that the author of the letter refers to the deliveryman only by name, which implies that the addressee must have known the person as well, and that the mentioned herbs came from "the garden", probably family property, suggests that the provisions were sent on a private basis and not on account of a state office. It can be followed that it was a common practice for families to supply relatives in the army if they could afford it, in addition to their official payments and food rations (see also above $\S 4.3$ ).

According to the Annals of Thutmose III, fields taken in possession by the Egyptian state in subjugated territories became royal property administered by Royal Agents, rwD.w n.w pr-nsw. After the battle of Megiddo, the crops from the enemy's fields were harvested and confiscated by the crown. It is also mentioned that some grain had already been cut during the assault by the Egyptian forces. ${ }^{268}$ The text does not say, however, where the wheat was brought. That, for instance, an Egyptian granary was located at Jaffa (ancient Joppa) during the early $19^{\text {th }}$ Dynasty, can be concluded from the letter sent by the Ugaritian governor Takuhlina to Haya/Huy discussed above (see $\S 4.4 .2$ ). ${ }^{269}$ According to this communication, Takuhlina has shipped 15 tons of wheat to the granary at Jaffa. From around the same time, a massive building containing a grain repository was found at Beth Shan. ${ }^{270}$ Huge storehouses

${ }^{263}$ H. Guksch, Königsdienst. Zur Selbstdarstellung der Beamten in der 18. Dynastie (Heidelberg: SAGA 11, 1994), 186 cat. No. (072)01, 187 cat.No. (072)03, and 187f. cat.No. (072)5.

${ }^{264}$ L. 5 of Qenamun's stela in TT 93, N. de Garis Davies, The Tomb of Ken-Amun at Thebes (New York: 1930) pl. 44, and cf. Hirsch, in: Der ägyptische Hof, 131. Cf. also the combat epithets alluding to the military missions of the Royal Herald Djehutimose, owner of TT 342, fragment of a stela in the Cairo Museum, TN. 21.3.25.14, perhaps originally from his Theban Tomb dating to the period of Thutmose III, 11. +2-3, Selim, in: Studies in Honor of Ali Radwan II, 333-337, fig. 2, pl. II, see already above $\S 4.3$.

${ }^{265}$ pAnastasi V 19,2-20,6, Gardiner, LEM, 66f., Caminos, LEM, 254-258.

266 Morris, Architecture of Imperialism, 415-424.

${ }^{267}$ pAnastasi V 20,6-21,8, Gardiner, LEM, 67f.; Caminos, LEM, 258-260.

268 Annals of Thutmose III on his Megiddo battle, 11. 102-103, Urk. IV, 667:10-15, and see Redford, Wars in Syria, 42f., and cf. ibid., 219.

${ }^{269}$ See above $37 \mathrm{f}$.

${ }^{270}$ A. Mazar, „Four Thousand Years of History at Tel Beth-Shean: An Account of the Renewed Excavations“, Biblical Archaeologist 60.2 (1997), 68f.; Mazar, in: Egypt, Canaan and Israel, 165-166 and fig. 6, 178-179, and Morris, Architecture of Imperialism, 609. 
are archaeologically documented for the $19^{\text {th }}$ Dynasty residencies at Deir el-Balah, Tel Mor, Aphek, and perhaps also at Beth Shan. ${ }^{271}$ Olive oil production seems to have been an important industry in the region of Beth Shan. ${ }^{272}$ Vineyards in the northeastern Delta were exploited by the occupants of the frontier fortress of Sile from the reign of Amenhotep III. ${ }^{273}$ The wine was sent to the Residence as part of the Egyptian tax collections. Other products shipped from Sile were moringa-oil, ${ }^{274}$ honey, ${ }^{275}$ but also Levantine wine (jrp nj 7 Arw) ${ }^{276}$ and Qedy-beer. ${ }^{277}$ While honey and oil might have been locally produced, the mentioned foreign place-names show that the fortress of Sile also served as a storage place of foreign products to be shipped to Egypt. ${ }^{278}$ Storehouses at the fortress are already documented for the early $18^{\text {th }}$ Dynasty. The products were either part of the taxes imposed on vassal rulers, who transferred them to Egypt, or supplies produced under imperial control at Egyptian bases: Situated directly adjacent to the $19^{\text {th }}$ Dynasty "palace" of Aphek were two wine presses, each of which had a collection basin to hold a capacity of 3,500 liters of liquid. ${ }^{279}$ The location of the processing area may suggest a direct exploitation of the local viticulture by the Egyptians. ${ }^{280}$ At Sile, a series of granaries already existing during the early $18^{\text {th }}$ Dynasty and fit to store about 180 metric tons of grain are consistent with the use of the fort as point of departure of the Egyptian army leaving for campaigns up north. Numerous kilns for baking bread were built next to them, indicating that industrial food production took place at the side. ${ }^{281} \mathrm{On}$ pKoller, a list of equipment for chariots leaving on a military campaign comprises, beside the weaponry, fodder and finely chopped straw in containers for the horses, while the soldiers' bread (kyllestis) was carried in haversacks. For this purpose, donkeys were brought along, each of them supervised by two drivers. The horses, by contrast, were watched and fed by stablemasters and grooms. ${ }^{282}$

Provisioning more than 8'000 men including 5'000 soldiers, 200 sailors, 50 charioteers with their horses (a contingent of at least 50 teams), 50 desert-policemen, and some military administrators and controllers, the big quarrying expedition to the Wadi Hammamat early in the reign of Ramesses IV was accompanied by 10 large carts full of supplies, each pulled by 6 teams of oxen, and by carriers laden with "bread, meat, and cakes" beside a great variety of offerings to the gods. ${ }^{283}$ While Ramesses IV's stela does not relate precise quantities of food

\footnotetext{
${ }^{271}$ Morris, Architecture of Imperialism, 559f., 578, 607.

272 See again Mazar, in: Egypt, Canaan and Israel, 178.

${ }^{273}$ See W.C. Hayes, „Inscriptions from the Palace of Amenhotep III“, JNES 10 (1951), 88f., and the detailed discussion of wine dockets from the late $18^{\text {th }}$ Dynasty by Morris, Architecture of Imperialism, 276-285.

${ }^{274}$ Hayes, JNES 10 (1951), 159 No. EE, fig. 27 EE.

${ }^{275}$ Hayes, JNES 10 (1951), 159 No. CC fig. 27 DD.

${ }^{276}$ Hayes, JNES 10 (1951), 89 no. 77 fig. 7 No. 77.

${ }^{277}$ Hayes, JNES 10 (1951), fig. 9 No. 118, and C. Hope, Malkata and the Birket Habu 1971-74, No. 2 vol. 5. Jar Sealings and Amphorae (Warminster: Egyptology Today, 1977), 75 with reference to an inscribed jar fragment

K 346, mentioning srm.t-bear from Qedy. Cf. also M. Peters-Destéract, Pain, bière et toutes bonnes choses...

L'alimentation dans l'Égypte ancienne (Lonrai: 2005), 176.

278 The mentioned products also appear in a lexicographical list that specifies the diversity of products to be held ready for remunerating an army returning from a military campaign, see pAnastasi IV 14,11 (honey); 15,4, where it is said that moringa-oil was brought from Naharina in Syria, 16,1 (Levantine wine and Qdy-beer) and 16,4 (beer from Qedy). From the latter passage, we know, however, that Qdy-beer was also produced in Egypt, Gardiner, LEM, 52, and Caminos, LEM, 200, and see also below.

${ }^{279}$ P. Beck, M. Kochavi, „A Dated Assemblage of the Late 13th Century B.C.E. from the Egyptian Residency at Aphek“, Tel Aviv 12 (1985), 32.

${ }^{280}$ Morris, Architecture of Imperialism, 582.

${ }^{281}$ Abd el-Maksoud, Tell Heboua 36, 48f., 114-120 and 122, and Morris, Architecture of Imperialism, 59f.

282 pKoller 1,1-2,2, Gardiner, LEM, 116f., Caminos, LEM, 431-436.

${ }^{283}$ Ll. 19-22 of the inscription, J. Couyat and P. Montet, Les inscriptions hiéroglyphiques et hiératiques du Ouâdi Hammâmât (Cairo: MIFAO 34, 1912), 34-39 No. 12, pl. 4 (KRI VI, 14:9-15), and see above n. 141.
} 
and other supplies, a quarrying inscription by Sethy I in Gebel es-Silsila is more detailed. The king states that for a workforce of an army of 1'000 men and the crews of the transport ships, he spent per capita "20 Deben (about 1' $800 \mathrm{~g}$ ) of bread twice a day, bundles of vegetables, roasted meat, and two sacks of grain each month". The royal messenger, who was in charge of the enterprise, received "best bread, beef, wine, sweet moringa-oil and sesame-oil, pomegranate-wine, honey, figs, grapes, fish, and vegetables each day, and likewise the great flower-bouquet of His Majesty, L.P.H., daily" from the temple of Sobek Lord of Gebel esSilsila. The Standard-Bearers of his army, in contrast, received "6 sacks of grain delivered from the granaries". ${ }^{284}$

In the $19^{\text {th }}$ Dynasty fortress of Umm el-Rakham situated at the Libyan border, grain was supplied by local agriculture, but also by import on ships. So far, there is archaeological evidence for four granaries of about $14 \mathrm{~m}^{3}$ each, which corresponds to a maximal storage capacity of about 56,000 litres. In order to provide occupants and animals at the fort with water, wells had been dug. ${ }^{285}$ At other sites, which were set at the major military route of the Way of Horus like Bir el-'Abd or Deir el-Balah, water reservoirs were maintained. Bir el'Abd also supplied grain silos, which could store up to 40 tons of grain. Since the area around the base was rather barren, the grain must have been imported from Egypt or from the Levant. 286

In Tel Sera', one of the two southern Canaanite bases still occupied in the $20^{\text {th }}$ Dynasty (the other is Tell el-Far'ah further south), some bowls and pottery sherds inscribed with hieratic dockets have been found at the so-called residency, an administrative building, giving insight into grain transactions in Canaan around the time of Ramesses III. ${ }^{287}$ The inscriptions are notations of payments measuring 460 up to 2,000 hekat (i.e., about 33,500-145,652 liters) of grain. ${ }^{288} \mathrm{O}$. Goldwasser points out that the same Egyptian-style type of bowls was found in large quantities in contemporary sanctuaries at Lachish and Beth Shan, ${ }^{289}$ which would strengthen the thesis that also the bowls from Tel Sera' were used as a kind of votive gift to a local or an imported Egyptian deity. In the latter case, one could also imagine that part of the grain was transferred to the main temple in Egypt. One of the bowls mentions the source of the provisions, a pr-domain. ${ }^{290}$ The large amounts of grain noted in the dockets would suggest a public institution rather than private donators. In analogy with the prosopographical evidence of Egyptian officials in the Levant, a royal domain seems most likely, run by a Superintendant of the kind of the Army-Commander Ramesses-user-khepesh from Beth Shan mentioned above. He was constrained to "provide for every granary", which might have been related to the royal residency at Beth Shan. ${ }^{291}$

Agriculturally, the Nubian province was much less productive than the northern regions. ${ }^{292}$ Some of the residential centers served as production centers for the state and the elite and/or as depots for the supply of Egyptian residents and military installations. The most important

\footnotetext{
${ }^{284}$ Rock inscription at East Silsila, 1. 9, 11. 10-12, 11. 12-13, KRI I, 60:13-14; 61:2-3, and 61:5; RITA Translations I, 52f., Davies, Egyptian Historical Inscriptions, 202f., and cf. Hikade, Expeditionswesen, 48f., 227f. Cat.No. 194.

285 S. Snape, "Vor der Kaserne: External Supply and Self-Sufficiency at Zawiyet Umm el-Rakham", in: Cities and Urbanism in Ancient Egypt. Papers from a Workshop in November 2006 at the Austrian Academy of Sciences, M. Bietak, E. Czerny, and I. Forstner-Müller eds. (Vienna: UZKÖAI 35: 2010), $283 f$.

${ }^{286}$ Morris, Architecture of Imperialism, 297-299, 302-305.

${ }^{287}$ Morris, Architecture of Imperialism, 752-754.

${ }^{288}$ O. Goldwasser, „Hieratic Inscriptions from Tel Sera’ in Southern Canaan“, Tel Aviv 11 (1984), 77-93, pls. 47, and Morris, Architecture of Imperialism, 753.

${ }^{289}$ Goldwasser, Tel Aviv 11 (1984), 85f.

${ }^{290}$ Bowl No. 2, Goldwasser, Tel Aviv 11 (1984), 80, fig. 2, pl. 5:2.

${ }^{291}$ Ward, in: James, The Iron Age at Beth Shan, fig. 96:1, 3.

${ }^{292}$ Information presented here are largely drawn from Morkot, in: Actes de la VIIIe conférence internationale des études Nubiennes, 175-189.
} 
stakeholders of land and agricultural production were state offices and temples. According to the Nauri Decree left by Sethy I, this king's temple at Abydos profited from Nubian fish pools, cattle, goats, birds and other animals. Among its employees were beekeepers, gardeners, and vintners, even though most of the wine allocated to the higher-ranking officials in the fortress-towns was imported from Egypt. ${ }^{293}$ The Nauri Decree also suggests that there was a certain practice by the Nubian government and its representatives, including high military personnel, to claim manpower, ships, their loads, fields or cattle belonging to a temple such as Sethy's Mansion of Millions of Years at Abydos for their own purposes (see also above $\S \S 3.2$ and 4.2). Thus, it seems that military commanders in Nubia were used to draw from state resources at hand whenever they were in need and they felt entitled to.

Keeping chariot-horses afforded arable land to produce enough fodder for the animals. Again a fictive letter on pSallier I can give some insight into animal husbandry connected with the most expensive and prestigious branch of the military, the chariotry: ${ }^{294}$ The model letter suggests that the head of the stable (in this case the Stable-Master of the Great Stable of the King at the Residence) administered the fields on which fodder for the horses was grown. As horses from the Royal Stable were concerned, the fields were situated on Pharaoh's property. Once assigned to the Stable, they should be recorded and filed at the Royal Granary, while another copy should be kept under wraps. ${ }^{295}$ The title-holder who authorized the allotments of land was the Chief-Keeper of Documents at the Royal Treasury. This shows again the close relationship between the administration of the King's House and the military. While many other documents contain complaints against the abuse of power by the army ( $\S$ 4.2), in this letter criticism goes the other way around as a Royal Stable-Master complains about the unauthorized confiscation of land assigned to the stable by an Intendant of the King's Mansion of Millions of Years (i.e., of Ramesses II) at Thebes.

According to the Amarna correspondence, troops and horses stationed in the north in one of the Egyptian bases or crossing the Levant on a military campaign were housed and fed by native rulers allied with Egypt. Supplies for men and animals included beer, wine, cattle, poultry, and small cattle, honey, oil, grain, water and straw. Vassals were also obliged to dispatch military units and ships in order to assist the Egyptians in military campaigns, to provide horses, donkeys, cattle, all kinds of food, and tents for the soldiers or to cultivate the lands under Egyptian administration around garrison cities. ${ }^{296}$ Also, pAnastasi I refers to this common practice during the period of Egyptian imperialism in the Levant: ${ }^{297}$ Provisions prepared by a Syro-Palestinian ally for an army counting 5,000 men, for which the Semitic term SImt "peace gift" was used, comprised two bread-types, small cattle and wine. The quantity of rations that was charged to the local ruler had to be accurately calculated by the army scribe, who again was responsible to the commander of the campaign.

A text from the Late Egyptian Miscellanies instructs in provisions to be prepared for the arrival of Pharaoh on his way back home from a military campaign. ${ }^{298}$ Neither the sender nor

\footnotetext{
${ }^{293}$ Cf. Säve-Söderbergh, Ägypten und Nubien, 199f.; jar sealings found at Buhen point to wine import from Egypt as well as from local (Nubian) production, Smith, Buhen, 162-179, on imports to Buhen during the New Kingdom ibid., 180-189.

${ }^{294}$ pSallier I 9,1-9, Gardiner, LEM, 87f., Caminos, LEM, 325-329.

295 The terminus technicus used here is snn jp.w Xr jnb.t, pSallier I 9,8.

296 See A.R. Schulman, „Some Observations on the Military Background of the Amarna Period“, JARCE 3 (1964), 63f. with a list of letters in $\mathrm{n} .99$, which contain or answer to royal orders to prepare supplies or troops before the arrival of an Egyptian army. Cf., on more general terms, N. Na'aman, „Economic Aspects of the Egyptian Occupation of Canaan“, Israel Exploration Journal 31 (1981), 172-185; id., „The Egyptian-Canaanite Correspondence“, in: Amarna Diplomacy, 132, and Fischer-Elfert, Satirische Streitschrift. Übersetzung, 155. ${ }^{297}$ pAnastasi I 17,2-18,2, Fischer-Elfert, Satirische Streitschrift. Textzusammenstellung, 119-122; id., Satirische Streitschrift. Übersetzung, 148-157.

${ }^{298}$ pAnastasi IV 13,8-17,9 (in parts also copied on pKoller 5,5-8, and pAnastasi IIIA 1-8), Gardiner, LEM, 4954, Caminos, LEM, 198-219.
} 
the addressee of the letter are mentioned, but from a passage that lists different kinds of ointments to be allocated at the arrival it can be inferred that the main recipients were the king's "army and chariotry". ${ }^{299}$ Although the sheer diversity of the mentioned items, nicely grouped according to product types, characterizes the letter as a didactic text, exploring the lexicon connected with state logistics and provisioning, it gives an idea about the victuals and allowances in kind awaiting an army returning from the battle field. These consisted of various kinds of breads, among them one thousand loaves of kemeh-kyllestis-bread ${ }^{300}$ intended as provisions for the army, while high-quality bread was meant for high-ranking persons: ${ }^{301}$

\section{"The big, good baked bread is meant as provisions for the great ones, while kemeh-bread and mixed bread of the Asiatics (Sbn<.w> $\mathrm{n}$ aAm.w) will be the provisions of the army. They will be in trays below the window of appearance of the right sight".}

According to this passage, the listed supplies were, in fact, part of the recompensation of the army, which took place in public and was carried out by the king himself, who rewarded soldiers and commanders personally by receiving and honoring them below the window of appearance. ${ }^{302}$ Beside the bread rations, the full range of victuals comprised cakes, dried meat, entrails, milk products, fruits, vegetables and herbs, geese, grain, honey, and (fresh) meat, also reeds, wood, weed and charcoal, incense and different kinds of oils and unguents, cattle, poultry and fish, as well as different kinds of drinks such as Egyptian and Qedy-beer, ${ }^{303}$ Levantine wine and special beverages for the servants. ${ }^{304}$

\section{$\S$ 4.5. Soldiers' civil careers: Aspects of a loyalistic model of the state}

In terms of government appointments, New Kingdom Egypt was not very far from its modern counterpart. Up to this day, army commanders build the government and set themselves up as state leaders, securing their power by filling important government posts with military colleagues or handing over to them important economic enterprises, although most recently, in a period of political change, the old clannish elite may loose power and give way to a more democratic system.

First struggling for political independence from foreign domination (Hyksos), then indulging in expansionistic goals, also the rulers of the New Kingdom belonged to the military elite and were heavily dependent on the efficiency and reliability of their armed forces (see $\S 2$ ). Ever since, trusted soldiers were granted special remuneration in form of luxury goods, allotment of land and slaves, exclusive royal presents and provisions, while

\footnotetext{
${ }^{299}$ pAnastasi IV 15,4-5.

${ }^{300}$ Kyllestis-bread was also mentioned among the products sent by a family to a Troop Commander on mission abroad (see above).

${ }^{301}$ pAnastasi IV 17,5-7.

${ }^{302}$ A similar procedure is described in the Annals of Amenemhet II, 1l. $\mathrm{x}+25-26$, H. Altenmüller and A.M. Moussa, „Die Inschrift Amenemhets II. aus dem Ptah-Tempel von Memphis. Vorbericht“, SAK 18 (1991), 18, and later on in Horemheb's Decree, see above $\S$ 4.1. In an iconographic parallel to the scene described in the text, the stela of Mesu from Qantir/Piramesse, now Hildesheim Pelizaeus-Museum 374, dating to Ramesses II, shows in the lower part the king rewarding the army (pA mSa r-Dr=f), with the owner next to the king and his statue, H. Kayser, Die ägyptischen Altertümer im Roemer-Pelizaeus-Museum in Hildesheim (Hildesheim 1973), 59f., Abb. 51, and Vomberg, Erscheinungsfenster, 235f., fig. 136 with bibliography.

${ }^{303}$ According to the passage, Qdy-beer, originally a foreign beverage, was also produced in Egypt: „Every (grown) man among them (i.e., the service staff consisting of young men) will be at the production sites and prepare Qdy-beer für the King's House, L.P.H., and seasoned(?) ale (srm.t nj tA an.t)“, pAnastasi IV 16,3-4. ${ }^{304} \mathrm{pAwr}$ is an unknown drink of inferior quality, see Caminos, LEM, $157 \mathrm{f}$.
} 
from the $18^{\text {th }}$ Dynasty it became common practice to install them in prestigious positions within the state, town or temple administration, most often connected with considerable economic profit. ${ }^{305}$ This purpose is made quite clear in a royal decree issued in favour of an earned Commander of the Royal Fleet, Nebamun, dating to the middle of the $18^{\text {th }}$ Dynasty: ${ }^{306}$

"Year 6. Order issued in the Majesty of the Palace, L.P.H., on this day for the Governor and Commander of the Ships of Upper-and Lower-Egypt. The order says: 'My Majesty, L.P.H., has ordered (to the effect that) you may receive a good old age by favour of the King in order to satisfy the needs of the Standard-Bearer of the Royal Ship Meri[imen] Nebamun after he has reached old age while following Pharaoh, L.P.H., in (his) presence truthfully, improving every day in doing what has been ordered to him without being blamed, nor have I found (any) reproof (in him), instead, the firebrand (lit.: producer of heat) was reported to him. Then My Majesty, L.P.H., appointed him Head of the Police on the Westside of Thebes (Hrj-mDAy.w $\mathrm{Hr}$ jmnt.t (As.t) at the entire site(?) and at the site "Great is the Power", until he has reached the status of reverence. And I gave him household staff, cattle, fields, servants, and property on water and on land, without allowing them to be interfered with by any agent of the King, any Standard-Bearer of (the Ship) Meryamun, or any veteran of the $[\text { crew? }]^{307}[\ldots \ldots . . . . ., "$

The position of a Chef of the Police at Thebes required an official residence equipped with all the commodities an elite household demanded. Parts of his property, including his house, are depicted in his Theban tomb. ${ }^{308}$ A similar text has survived from the reign of Ramesses II, although in this case the promotion of a career soldier to Head of the Desert Police (wr nj mDAy.w) and Director of Works in the temple of Ramesses II at Western Thebes was sanctioned by a divine resolution in the temple of his hometown Koptos. ${ }^{309}$

In contrast to the Ramesside military, officers of the $18^{\text {th }}$ Dynasty who ended up their career as state officials did barely refer to their former military ranks. ${ }^{310}$ A stereotype often used in biographies or tomb inscriptions to describe active military service was to present themselves as "Royal Retainers" or "Followers of the King/at the King's Feet to Foreign Countries" on campaigns to Nubia or Canaan. ${ }^{311}$ Some of them were foster brothers of the

\footnotetext{
${ }^{305}$ See above $\S 2$ and, in general, Gnirs, Militär und Gesellschaft.

${ }^{306}$ TT 90, transverse hall, west wall, south side, Davies and Davies, The Tombs of Two Officials, 35, pl. 26, and Säve-Söderbergh, The Navy, 83f.

${ }^{307}$ Davies and Davies, The Tombs of Two Officials, pl. 26, complements [t]nj nj p[A]j[j] [...], ,,veteran of the soldiery(?)“, but could also be completed to [t]nj nj pA [Xn]j[j.t] [...].

${ }^{308}$ TT 90, transverse hall, west wall, north side, Davies and Davies, The Tombs of Two Officials, pl. 30 (a garden with pond, a vineyard, and a wine press) and pls. 33-34 (house).

${ }^{309}$ Stela of Penra from Koptos, a former Troop-Commander, Director of Foreign Countries in the Levant, and Charioteer of the King, Ashmolean Museum 1894.106d, KRI III, 270-271, RITA Translations III, 192f.), and S. Gohary, „The Remarkable Career of a Police Officer“", ASAE 71 (1987), 97-100 and fig. 1. For his professional history see Gnirs, Militär und Gesellschaft, 156f. Cf. also, above $\S 4.3$, the later career of the officer Amenemone.

${ }^{310}$ See, in contrast, Redford, Wars in Syria, 195-197, who argues that at the time of Thutmose III, the military entourage of the king broadly consisted of civil title-holders: „... the core of recruited force, i.e., those immediately surrounding the king, were drawn from household, administration, or ,the nursery"“".

${ }^{311}$ See biographies of the earlier $18^{\text {th }}$ Dynasty translated by Redford, Wars in Syria, 165-181, and H. Guksch, Königsdienst, 58-61, 65-67. Shirley, in: Egypt, Canaan and Israel, 291-319, however, argues that some of these
} 
future king, who had enjoyed military training side by side with the princes at court and were, thus, apt to follow their lord on military operations abroad. Qenamun, the famous Superintendant of the Royal Estate at Perunefer under Amenhotep II, was one of them. Having served as a Standard-Bearer, Fortress-Commander and imperial tax collector in his early years (see above $\S 4.4 .2$ ), he ended up as Overseer of the Cattle of Amun and Governor, First Royal Herald and finally as Royal Superintendant, taking over a series of prestigious economic and politically important positions in the royal administration. His rather unusual biography inscribed on a model shabti coffin dedicated to his mother ${ }^{312}$ gives a glimpse of the circumstances in which a royal favour resulted in promotions and privileges: ${ }^{313}$
"When I was on the curricle (Htrj) alone with him, he told me about
his decision to make me first of the whole country, without being there anybody equal to me.
He confided to me many horses, fresh and beautiful, 50 were
harnessed for me, when I followed his Majesty.
He entrusted to me many prestigious positions from the (best) choices of the Black Land. His great ones saw me how I was greeted and how the earth was kissed in presence (of the king), when I was with him. I was sweeter (to him) than his (own) son, when he looked at me, to the delight of the Overseer of Cattle Qenamun."

Qenamun's records allow a portrait of his personal history. Grown up as a foster brother of the crownprince and as his comrade-in-arms, he accompanies the king as a young man on military campaigns. Common experiences and Qenamun's efficiency prompt the king to entrust him with leadership roles in the army, where he advances into the positions of a Standard-Bearer, Fortress-Commander and finally to the prestigious post of a Stablemaster of the royal horses (see also $\S 4.4 .2$ ). As imperial executive sent to the Levant for collecting taxes, he becomes well acquainted with the royal administration, in particular, the Royal Treasure and the Treasury, a qualification that might later have facilitated his promotion into the ranks of the Overseer of Cattle and of the King's Superintendant.

Bureaucratic careers launched by former officers can also be retraced for the Ramesside Period. After the establishment of a professional army, a process that was completed at the end of the $18^{\text {th }}$ Dynasty, ${ }^{314}$ career soldiers did usually not leave the military organization except for entering the Nubian imperial administration, where they could rise to the position of the Troop-Commander of Kush or even that of the Viceroy. ${ }^{315}$ Although Ramesside biographies of soldiers are rare at that time, as the genre had shifted its focus from the individual's social integration towards religious behaviour and divine service, ${ }^{316}$ historical records, mostly title sequences, sometimes allow for reconstructing major career moves. Paser, for instance, who lived at the end of the $18^{\text {th }}$ Dynasty, passed from the ranks of a Standard-Bearer and Stablemaster to that of a Marshall, until he finally qualified for the position of the Governor of Nubia at the end of his professional life, succeeding his father

officials carried out only civil functions during the wars their kings waged abroad, such as the collection of taxes or tributes, and that they never held military ranks. Cf. again above $\S 4.4 .2$.

${ }^{312}$ For references see above n. 257.

${ }^{313}$ L1. 16-29, Pumpenmeier, Schabtidepot, 18, fig. 6 and pl. 4 below and center right.

${ }^{314}$ Gnirs, Militär und Gesellschaft, 17-34.

315 Gnirs, Militär und Gesellschaft, 66-79, 134-139.

${ }^{316}$ Cf. A.M. Gnirs, „Autobiography“, in: Ancient Egyptian Literature. History and Forms, A. Loprieno ed. (Leiden, New York, Köln: PdÄ 10, 1996), 233-236, and E. Frood, Biographical Texts from Ramessid Egypt (Atlanta: Writings from the Ancient World, 2007), 19-23, 24-26. 
Amenhotep/Huy in office ${ }^{317}$ Huy's military past had been quite similar to that of his son: He held the rank of jdnw nj $\mathrm{Hm}=f \mathrm{~m}$ tj n.t-Htrj, „Lieutenant-Commander of His Majesty in the Chariotry“, i.e., Commander-in-Chief of mobile forces, while his son as jmj-rA ssm.wt had been the strategic and administrative head of this branch of the professional army. ${ }^{318} \mathrm{~A}$ similar career can be retraced for a namesake of his and successor in office in the time of Ramesses II. This later Huy is known first to have been Troop Commander, then Marshal and King's Lieutenant-Commander in the Chariotry. Before he was appointed Viceroy of Kush, he became involved as a Royal Envoy ${ }^{319}$ in the so-called First Hittite Marriage of Ramesses II, a diplomatic act of highest priority pursued by both Egypt and Khatti in order to strengthen their peace treaty. ${ }^{320}$ In one of his inscriptions, he is said to have "come to Khatti, brought her Princess (from her homeland to the Egyptian border) and reported all that which has never happened before". The official version of the same event, which refers to the King's troops and chariots mixed with those of the Hittites to escort the princess and the international delegation, ${ }^{321}$ shows that his military qualification as a Troop Commander of Sile and Commander-in-Chief of the Chariotry made him suitable for this delicate mission.

High-ranking combat soldiers did not usually switch from active military service to the administrative headquarters of the army to obtain the rank of a jmj-rA mSa (wr) and to enter from there an office in the upper royal bureaucracy. Some of them, however, broke this rule like Iupa and his father Urkhija early in the $19^{\text {th }}$ Dynasty. ${ }^{322}$ Originally from a Hurrian background, Urkhija must have made his career as a Troop-Commander of the King in the reign of Sethy I. His unusual promotion into the rank of a Commander-in-Chief of the Army, jmj-rA mSa wr, which brought him into the highest senior executive position in the military organization, paved his way for entering the royal administration as a Majordomus of the King's Mansion of Millions of Years at Thebes under Ramesses II. As Urkhija also bore the title of a Director of Works, a function that was often assigned to Army Commanders, he might have been involved in the construction of the mentioned temple at Western Thebes.

\footnotetext{
${ }^{317}$ Gnirs, Militär und Gesellschaft, 73f. The combination of the titles TAj-sry.t and Hrj-jHw is uncommon in the Ramesside Period. See, however, Qenamun's professional history described in his biography above.

318 Owner of Theben Tomb No. 40, Davies, Tomb of Huy, and see above $\S$ 4.4.1.

319 The diplomatic corps between Egypt and Khatti consisted of Hittite and Egyptian envoys, the wp.wtj-nsw Netjeruimes/Nemtimes(?) alias Parekhnu(a)/Parihnawa (Babylonian) probably being the most prominent Egyptian official involved in the formation of the peace treaty as well as in Ramesses' First Diplomatic

Marriage, Roth, in: Der ägyptische Hof, 97f. with n. 39. On the reading of his name as Nmtj-ms see M. Müller, Akkadisch in Keilschrifttexten aus Ägypten. Deskriptive Grammatik einer Interlanguage des späten zweiten vorchristlichen Jahrtausends anhand der Ramses-Briefe (Münster: AUAT 373, 2010), 16, with further bibliography. His tomb in the Memphite necropolis, called Bubasteion I.16 by its excavators, was discovered by A. Zivie, Les tombeaux retrouvés de Saqqara (Monaco: 2003), 120-141, and id., „Le messager royal égyptien Pirikhnawa", BMSAES 6 (2006), 68-78. According to his tomb inscriptions, Zivie, BMSAES 6 (2006), 69 and 74f. figs. 3-4, and id., Tombeaux retrouvés, pls. on p. 121, 123, he held a high position at the Royal Residence, being Director of the Treasury as well as Superintendant of the Royal Estate at Memphis. In this function, also Haremhab, the later king, acted as a delegate and negotiating partner with foreign delegations, see also above $\S$ 2.

${ }^{320}$ Stela Berlin 17332, 11. 3-5, KRI III, 79:15-80:1, and RITA III, 55, and cf. K.A. Kitchen, „High Society and Lower Ranks in Ramesside Egypt at Home and Abroad“, BMSAES 6 (2006), 32, who translates the phrase jj $\mathrm{Hr}$ $\approx \mathrm{tA}$,who came from the Hatti-land" (cursive by the author). See also above pp. $37 \mathrm{f}$.

${ }^{321}$ Inscription at Abu Simbel, 11. 35-36 and 39-41 (KRI II, 248:4-15, 250:7-251:11), and Davies, Egyptian Historical Inscriptions, 117-143; cf. also H. Klengel, Hattuschili und Ramses. Hethiter und Ägypter-ihr langer Weg zum Frieden (Mainz: Kulturgeschichte der antiken Welt, 2002), 127-139; cf. also D. Lefevre, „Le marriage comme instrument politique au Proche-Orient ancien: Ramsès II et la princesse Hittite“, Égypte, Afrique \& Orient 39 (2005), 3-12; S. Roth, in: Der ägyptische Hof, 90f., 97f., 102-106.

${ }^{322}$ See Gnirs, Militär und Gesellschaft, 56f., 147f., and $180 \mathrm{f}$.
} 
Iupa first followed his father's steps to finally surpass the latter's career: It seems that he left the professional army sometime after he had become Marshal. Like his father, he was army commander and construction supervisor, who was involved at one of the building sites of the newly founded residence Piramesse, i.e., "the Great Stable of Ramessu-Meriimen", according to an account book from the $5^{\text {th }}$ year of Ramesses II, the so-called Paris Leather Roll. ${ }^{323}$ Later on during his career, he became not only Superintendant of the Ramesseum at Thebes, but also Director of the Treasury of the King and Director of the Granaries.

\section{$\S 5$ Conclusions}

The historical records of the New Kingdom show the flexibility of the Egyptian bureaucratic system, which allowed career moves between different departments, especially between the military and the higher royal administration, thus facilitating access to higher social and economic distinction. The shift of a professional elite from the military to the royal administration on the basis of seniority was a common practice not only in Egypt, but also in other ancient bureaucracies and point to a loyalist system of promotion. In the earlier New Kingdom, it seems that the military, broadly supported by the King's House, exerted a strong influence on other departments. Sources suggest that executive power was often delegated $a d$ personam according to relations with the king rather than according to institutional hierarchies. To fill important positions constantly from the higher echelons of the army worked against the natural tendency towards hereditary offices and the rise of powerful family clans. ${ }^{324}$ Apart from this, the military played a crucial role in politics and society throughout the New Kingdom, owing to its increasing interests abroad. One of the ideological cornerstones of Egyptian kinghsip was the submission of the outside world. While the king was always de iure supreme commander of Egypt's armed forces, during the late $18^{\text {th }}$ and the early $19^{\text {th }}$ Dynasty military expertise as essential condition for the claim to the throne was no longer taken for granted, but became an explicite requirement of royal succession expressed in the rank of a Commander-in-Chief of the Army. At the same time, the title "Regent" was introduced to designate the crown prince. At that point, kingship had given up its divine status in favour of a bureaucratic understanding of responsibilities $(\S 2)$.

In Egyptian society, demarcation lines between different spheres of competence were not clearly cut, as shown by a significant number of letters of complaints and royal decrees that refer to overlapping between military and bureaucratic institutions ( $\S 4.2$ and 4.4.3).

However, infringements by military personnel clearly prevailed, which led, at times, to new laws and exemption decrees. Most breaches occurred in the economic sphere wherever the military had direct access to manpower, facilities and supplies for the army. In contrast, the advantage of this "fuzzy" range between authorization and malfeasance characteristic of the interactions of the military with other state institutions was a fast and unbureaucratic implementation of royal projects and missions or of emergency cases and instant shortages.

Demarcation lines were, however, at work within the military organization. After the establishment of a permanent army, which strongly relied on specialized units such as bowmen troops, mercenaries and chariotry, combat soldiers and officers followed a different career than army commanders, military scribes and logistics managers, who constituted the upper army administration. While the latter often had access to prestigious offices connected with the King's House at the end of their professional lifetime, career soldiers did barely leave the army. When they moved up the career ladder, at best, they became Marshal or, on a more temporary basis, Lieutenant-Commander of the Chariotry. Experiences in royal missions

\footnotetext{
${ }^{323}$ Col. II, 1 and II,6, KRI II, 790:3 and 790:12. Piramesse was built during the first years of the reign of Ramesses II. In the account, the Great Stable of Ramesses-Meryamun is mentioned as the institution, for which Iupa had ordered a huge amount of mud bricks, cf. also Klengel, Hattuschil und Ramses, 109-111.

${ }^{324}$ Within the military, this is rarely documented, see, for instance, the founders of the 19th Dynasty, the Paramessu-family (§ 2), or the Iurkha/Jupa family (§ 4.5), Gnirs, Militär und Gesellschaft, 56f., 147f., 179-181.
} 
abroad and/or in armed conflicts qualified some of them for posts in the imperial tax and tribute administration, in the Egyptian diplomatic corps or in the provincial government of Nubia, where they could take over the most powerful positions of the Troop-Commander of Kush or of the Viceroy.

While during the New Kingdom Nubia was totally under Egyptian control, divided into two main provinces with different administrative key zones and a fully developed administration, Egypt's imperial grasp on the Levant was much looser and less bureaucratic due to the complex geo- and socio-political situation of the region, consisting of more or less independent political centers and kinglets. Although the King's House had built up a dense network of Egyptian bases and residencies at various locations and could rely in the north on a well established and rapidly working communication system between the Court and Egyptian representatives or vassals as well as on foreign infrastructure, Egypt never knew a hierarchically organized imperial government in Canaan comparable to that of Nubia. Except for the fortresses that were built already during the Middle Kingdom in Nubia and that were partly taken over as strategic and economic sites by the kingdom of Kerma during the Second Intermediate Period, after the defeat of the Kushites Egypt had to rebuild its own infrastructure in the reconquered south. Military presence was a general feature of Egyptian imperialism. While the Nubian government always underheld tight relations with the professional army, truly military operations were rare since local elites could be integrated into the imperial system soon after the reconquest of the province. The stationing of troops was mainly directed at protecting the exploitation of resources and their transport to Egypt and at guaranteeing a constant flow of trade goods and tribute back home. On the one hand, military bases in the Levant served similar purposes, on the other hand, they secured and defended Egypt's political claim on city-states and regions at local as well as at international level, using the zone as a buffer against expansionist interests of neighboring states such as the kingdom of Mitanni or that of Khatti. Vassal cities and states had to provide troops and chariots with victuals and other commodities, even with armed forces, while contingents based in Nubia were maintained on the basis of Egypt's own agricultural production in the Nile Valley. Owing to both its entitlement to maintenance and its constant contribution towards a full state purse, the army underheld close relations with royal institutions and, above all, the two major economic departments of the state, the Granaries and the Treasury, although it seems that official channels were often neglected when the military was in need of resources and material of any kind.

Archaeological evidence shows that military bases and fortresses were usually equipped with sustainance facilities. From model letters and administrative documents it can be inferred that the diet of soldiers stationed at strongholds or bases abroad was one-sided. Standard food was a particular bread-type, the so-called kyllestis-bread, which was also carried along as supplies during campaigning. While the logistics office of the army was responsible not only for conscribing recruits, but also for giving out soldiers' rations, provisions were, in fact, allocated by the Granaries' administration and related institutions. The function of a jdnw n

$\mathrm{mSa}$ was, thus, a truly administrative post at the intersection between bureaucracy and military. An intermediary nature also characterizes the position of a Commander of the Army, who was specialized in organizing and supervising armies on the battlefield as well as in quarries, mines, or on construction sites.

Also the navy was structurally located at the crossroads between army and bureaucracy. While transportation of troops by ship was always an important factor of warfare in the Nile valley and along the Mediterranean coast, New Kingdom Egypt did not really have a battle fleet with specialized war vessels and marines. Although we have ample documentation about soldiers and officers serving on ships, their titles suggest that in terms of combat techniques and organization, their domain of operation was not different from that of land troops. Naval 
warfare, i.e., the defense of Egypt's borders by ship, might have begun to develop quite late during the New Kingdom, around the time of Ramesses III, who fought the so-called seapeople on land and at sea as battle scenes on the walls of the Great Temple of Medinet Habu suggest (see above $\S 3.1$ ). In earlier history, vessels were used for transportation of troops, horses and arms or as mobile bases during warfare, but not for combat. A naval commander in charge of a ship equipped with soldiers was, therefore, on a par with a commander of land troops; his title was then interchangeable with that of a Standard-Bearer, but there was no specific naval ranking title confined to warfare only. Troop-Commanders deployed on ships, on the other hand, were not always sent on military missions, but could be in charge of the transportation of foreign goods or tribute, working then for the Royal Treasury. The same can be said about the Royal Fleet, which was deployable as navy in times of warfare, most often, however, as cargo fleet transporting goods and resources for royal temples or the Treasury. It is, therefore, not surprising that the fleet was administratively subordinated to the office of the vizier and not to a military cadre.

In conclusion, it is uncertain whether for New Kingdom Egypt we can speak of a true military organization at work. Although foreign policy did rely on a professionalized branch of the army and truly military careers can be traced in the historical records from the $18^{\text {th }}$ Dynasty onwards, the management and the administration of the army were closely intertwined with other departments, especially economic institutions. Egyptian bureaucracy as a whole seems to be characterized by "fuzzy" divisional, hierarchical as well as professional boundaries. This lack of clear-cut confines is a key aspect of a sociopolitical system based on royal patronage, which allowed an increase of professionalization only inasmuch as the network of royal power was not at stake. 